Article

\title{
Improving Scientific Knowledge of Mallorca Channel Seamounts (Western Mediterranean) within the Framework of Natura 2000 Network
}

\author{
Enric Massutí ${ }^{1, *}$, Olga Sánchez-Guillamón ${ }^{2}{ }^{\oplus}$, Maria Teresa Farriols ${ }^{1}\left(\mathbb{D}\right.$, Desirée Palomino ${ }^{2}{ }^{\circledR}$, Aida Frank ${ }^{1}$, \\ Patricia Bárcenas ${ }^{2}$, Beatriz Rincón ${ }^{3}$, Natalia Martínez-Carreño ${ }^{2}$, Stefanie Keller ${ }^{1}$, Carmina López-Rodríguez ${ }^{2}$, \\ Julio A. Díaz ${ }^{1}{ }^{\circledR}$, Nieves López-González ${ }^{2}{ }^{\mathbb{D}}$, Elena Marco-Herrero ${ }^{4}$, Ulla Fernandez-Arcaya ${ }^{3}{ }^{\mathbb{D}}$, Maria Valls ${ }^{1}{ }^{1}$, \\ Sergio Ramírez-Amaro ${ }^{1}$, Francesca Ferragut ${ }^{1}{ }^{1}$, Sergi Joher ${ }^{1}$, Francisco Ordinas ${ }^{1}$ and Juan-Tomás Vázquez ${ }^{2} \mathbb{C}$ \\ 1 Centre Oceanogràfic de les Balears, Instituto Español de Oceanografía (IEO-CSIC), 07015 Palma, Spain; \\ mt.farriols@ieo.es (M.T.F.); aida.frank@ieo.es (A.F.); stefanie.keller@ieo.es (S.K.); julio.diaz@ieo.es (J.A.D.); \\ maria.valls@ieo.es (M.V.); sergio.ramirez@ieo.es (S.R.-A.); isferragutperello@gmail.com (F.F.); \\ sergi.joher@ieo.es (S.J.); xisco.ordinas@ieo.es (F.O.) \\ 2 Centro Oceanográfico de Málaga, Instituto Español de Oceanografía (IEO-CSIC), 29640 Fuengirola, Spain; \\ olga.sanchez@ieo.es (O.S.-G.); desiree.palomino@ieo.es (D.P.); patricia.barcenas@ieo.es (P.B.); \\ natalia.martinez@ieo.es (N.M.-C.); carmina.lopez@ieo.es (C.L.-R.); nieves.lopez@ieo.es (N.L.-G.); \\ juantomas.vazquez@ieo.es (J.-T.V.) \\ 3 Centro Oceanográfico de Santander, Instituto Español de Oceanografía (IEO-CSIC), 39004 Santander, Spain; \\ beatriz.rincon@ieo.es (B.R.); ulla.fernandez@ieo.es (U.F.-A.) \\ check for \\ updates \\ Citation: Massutí, E.; \\ Sánchez-Guillamón, O.; Farriols, \\ 4 Centro Oceanográfico de Cádiz, Instituto Español de Oceanografía (IEO-CSIC), 11006 Cádiz, Spain; \\ elena.marco@ieo.es \\ * Correspondence: enric.massuti@ieo.es
}

M.T.; Palomino, D.; Frank, A.;

Bárcenas, P.; Rincón, B.;

Martínez-Carreño, N.; Keller, S.;

López-Rodríguez, C.; et al.

Improving Scientific Knowledge of

Mallorca Channel Seamounts

(Western Mediterranean) within the

Framework of Natura 2000 Network.

Diversity 2022, 14, 4. https://

doi.org/10.3390/d14010004

Academic Editors: Carlo Nike

Bianchi, Carla Morri and

Michael Wink

Received: 31 October 2021

Accepted: 17 December 2021

Published: 22 December 2021

Publisher's Note: MDPI stays neutral with regard to jurisdictional claims in published maps and institutional affiliations.

Copyright: (C) 2021 by the authors. Licensee MDPI, Basel, Switzerland. This article is an open access article distributed under the terms and conditions of the Creative Commons Attribution (CC BY) license (https:// creativecommons.org/licenses/by/ $4.0 /)$.
Abstract: The scientific exploration of Mallorca Channel seamounts (western Mediterranean) is improving the knowledge of the Ses Olives (SO), Ausias March (AM), and Emile Baudot (EB) seamounts for their inclusion in the Natura 2000 network. The aims are to map and characterize benthic species and habitats by means of a geological and biological multidisciplinary approach: high-resolution acoustics, sediment and rock dredges, beam trawl, bottom trawl, and underwater imagery. Among the seamounts, 15 different morphological features were differentiated, highlighting the presence of 4000 pockmarks, which are seafloor rounded depressions indicators of focused fluid flow escapes, usually gas and/or water, from beneath the seabed sediments. So far, a total of 547 species or taxa have been inventoried, with sponges, fishes, mollusks, and crustaceans the most diverse groups including new taxa and new geographical records. Up to 29 categories of benthic habitats have been found, highlighting those included in the Habitats Directive: maërl beds on the summits of AM and EB, pockmarks around the seamounts and coral reefs in their rocky escarpments as well as fields of Isidella elongata on sedimentary bathyal bottoms. Trawling is the main demersal fishery developed around SO and AM, which are targeted to deep water crustaceans: Parapenaeus longirostris, Nephrops norvegicus, and Aristeus antennatus. This study provides scientific information for the proposal of the Mallorca Channel seamounts as a Site of Community Importance and for its final declaration as a Special Area of Conservation.

Keywords: geomorphology; geodiversity; biodiversity; habitats; benthic communities; trawl fishing; seamounts; Natura 2000 network; Balearic Islands; Mediterranean

\section{Introduction}

The protection of marine species and ecosystems is especially relevant in the Mediterranean, which has been described as a hot spot of biodiversity [1]. Marine protected areas (MPAs) are recognized as useful tools for managing and enhancing marine species and ecosystems. MPAs can constitute a globally connected system for safeguarding biodiversity and maintaining the health of marine ecosystems and the services they provide. Through 
the Protocol Concerning Specially Protected Areas and Biological Diversity in the Mediterranean (SPA/BD Protocol), the Contracting Parties to the Barcelona Convention promote cooperation in the management and conservation of natural areas as well as in the protection of threatened species and their habitats. The Marine Strategy Framework Directive (MSFD) also includes a requirement for the European countries of the Mediterranean to establish an ecologically coherent network of MPAs to help protect vulnerable species and habitats [2]. In the European Union, the main instrument for protecting biodiversity is the Natura 2000 network, which seeks the stable maintenance or, where appropriate, the restoration to a favorable status of certain habitats and species including the marine environment.

The Natura 2000 network is composed of Sites of Community Importance (SCI), which are subsequently declared as Special Areas of Conservation (SAC). These protection regimes seek to ensure the long-term preservation of these areas and their flora and fauna as well as the sustainability of human activities carried out therein through the implementation of management plans. As a result of the LIFE INDEMARES project (https: / / www.indemares. es/en (accessed on 15 December 2021)) developed between 2009 and 2014 in Spain, 10 large marine areas were declared as SCI, half of them sited in the Mediterranean. With this, the total protected sea surface off Spain increased from $<1 \%$ to $>8 \%$, thus contributing to the objective of the Convention on Biological Diversity to protect $10 \%$ of marine regions by 2020 .

The current LIFE IP INTEMARES project (https:/ / intemares.es/en (accessed on 15 December 2021)) has the aim to complete this work. The scientific exploration of seamounts in the Mallorca Channel (Balearic Islands, western Mediterranean), developed within this project, is to improve the scientific knowledge of this area for its inclusion in the Natura 2000 network. The main objective is to map and characterize the benthic habitats and species of special interest for conservation, the most important human threats, and the vulnerability of the area to propose it as a SCI for the subsequent development of management plans and its final declaration as a SAC.

Seamounts are isolated undersea topographical elevations on continental margins and oceanic domains, which are considered as hotspots of biological activity and biodiversity in the deep-sea [3]. These relevant seafloor reliefs span a broad depth range, being influenced by different oceanographic processes [4] and located in diverse geodynamic settings. Therefore, they comprise heterogeneous habitat types [5], some of them structured by fragile, sessile, slow-growing, and long-lived species sensitive to fishing and other types of disturbance, being internationally recognized as Vulnerable Marine Ecosystems [6]. The scientific knowledge on Mediterranean seamounts is marked by large gaps and an asymmetry between the number of geological studies and biological ones [5].

Up to 60 seamounts and seamount-like structures have been identified in the western Mediterranean [7,8]. Among these are the Ses Olives (SO), Ausias March (AM), and Emile Baudot (EB) seamounts, currently studied within the INTEMARES project (Figure 1). Previous studies on these seamounts have analyzed the demersal fisheries targeted on deep water decapods crustaceans $[9,10]$, the geomorphology and geodynamics $[11,12]$, and the benthic species and habitats [13-17], suggesting their high ecological value. For this, the protection of these seamounts is recommended [18]. The present study includes the first results obtained in the INTEMARES project regarding the mapping and characterization of seafloor, benthic species, and habitats as well as fishing activity on SO, AM, and EB seamounts and adjacent bottoms. 

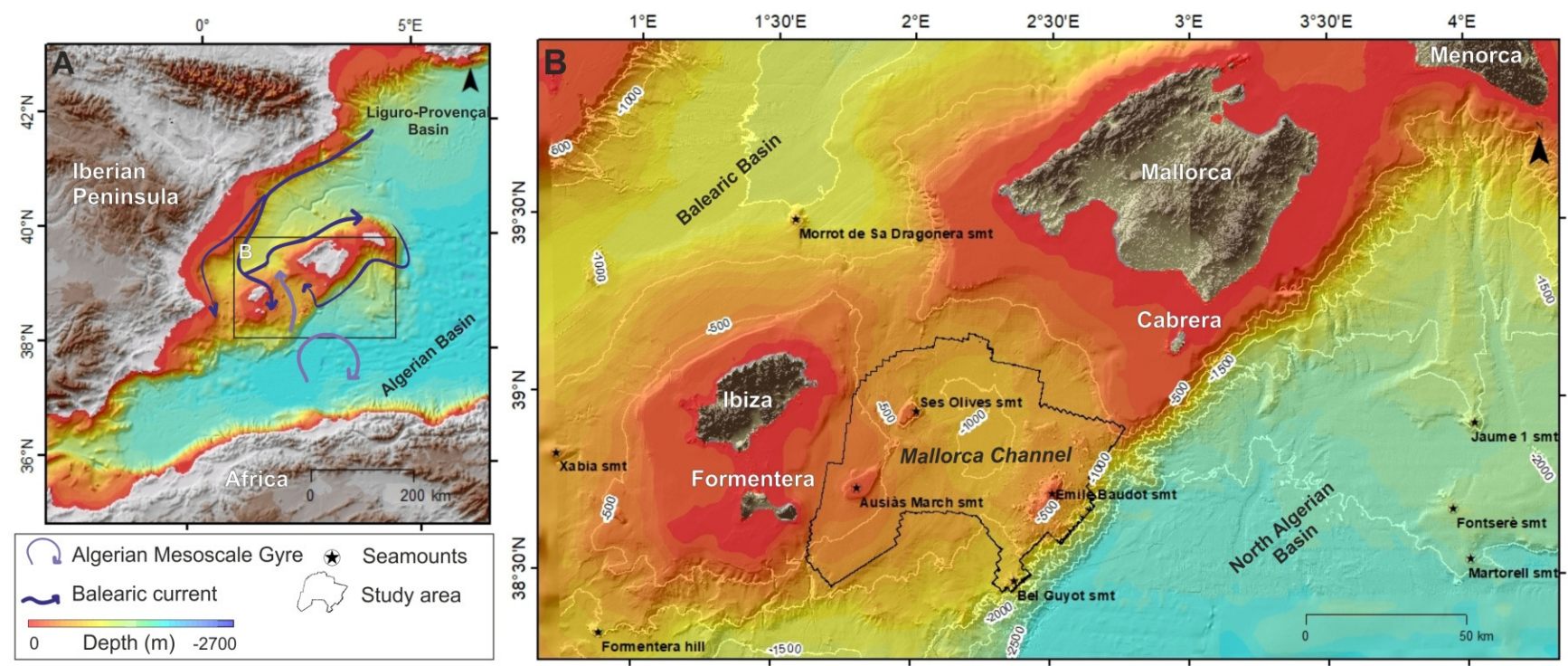

Figure 1. Map of the western Mediterranean showing (A) the Balearic Promontory and the (B) Ses Olives, Ausias March, and Emile Baudot seamounts and adjacent area of the Mallorca Channel currently studied within the INTEMARES project as well as other seamounts (smt) in the area. The western Mediterranean water mass circulation scheme is modified from López-Jurado et al. (2008).

\section{Study Area}

The Mallorca Channel corresponds to a seaway between the Ibiza and Mallorca islands, located southwest of the Balearic Promontory between the Valencia Trough to the west and the abyssal domain to the east (western Mediterranean). It can be described as an asymmetric channel, whose width varies between 100 and $200 \mathrm{~km}$, narrowing toward the north and deepening up to $1050 \mathrm{~m}$. It is characterized by the presence of a variety of morphological features such as seamounts, scarps, and depressions $[8,19]$. The three studied seamounts are located in this area, being situated east off Ibiza and the Formentera Islands in the case of SO and AM and south off Mallorca and the Cabrera Islands in the case of EB (Figure 1).

The Balearic promontory delimits the Balearic and Algerian sub-basins in the north and the south, respectively (Figure 1), with different oceanographic conditions [20]. The Balearic sub-basin is more influenced by atmospheric forcing and Mediterranean waters, which are colder and more saline, whereas the Algerian sub-basin is basically affected by density gradients and receives warmer and less saline Atlantic waters [21]. Different water masses can be found in both sub-basins [21,22]. The surface waters, coming from the Atlantic and called the Atlantic Waters (AW), have high seasonal temperature variation, ranging from $13{ }^{\circ} \mathrm{C}$ during winter to $26^{\circ} \mathrm{C}$ during summer, when a strong vertical temperature gradient is established between a 50 and $100 \mathrm{~m}$ depth. The Western Mediterranean Intermediate Water (WMIW) is found at 100-300 m depths and exhibits variable thickness. It is formed during winter in the Gulf of Lions by deep convection, when sea-air heat flux losses are high enough, being characterized by a minimum temperature $\left(\sim 12.5^{\circ} \mathrm{C}\right)$. The Levantine Intermediate Water (LIW), originating in the eastern Mediterranean, reaches the Balearic Islands after circulating through the northern part of the western Mediterranean. It shows maximum temperature and salinity $\left(\sim 13.3{ }^{\circ} \mathrm{C}\right.$ and $\sim 38.5$, respectively) and is found at 200-700 m depths, just above the Western Mediterranean Deep Water (WMDW), which is located in the deeper part of the water column.

The regional circulation in the western Mediterranean is dominated by the Northern Current, which carries down these intermediate waters along the continental slope of the Iberian Peninsula and bifurcates when reaching the Ibiza Channel [21,23]. One significant part crosses this channel flowing southward, and the other part cyclonically returns along the northern Balearic Islands, forming the Balearic Current (Figure 1). The composition 
of the waters passing through the Balearic channels are subject to inter-annual variations, depending on the amount of these waters reaching and passing these channels and the flows of the Atlantic Waters passing northward through Ibiza and Mallorca Channel [21,24,25].

Within the general oligotrophic environment of the Mediterranean, the waters around the Balearic Islands show more pronounced oligotrophy than the adjacent waters off the Iberian Peninsula and the Gulf of Lions, due to the lack of supply of nutrients from land runoff [26,27]. Frontal meso-scale events between Mediterranean and Atlantic waters [28] and input of old northern water into the channels [29] can act as external fertilization mechanisms that enhance productivity off the Balearic Islands.

These distinct hydrodynamic scenarios in the northern and southern Balearic Archipelago [30] could be on the basis of some differences observed in deep water ecosystems between the Algerian and the Balearic sub-basins: (i) trophic webs are supported more by plankton biomass than by benthic productivity, while supra-benthos plays a more important role, respectively [31,32]; and (ii) body condition of species is lower in the Algerian sub-basin than in the Balearic sub-basin, not only at an individual species level but also considering the whole assemblage [33]. The interannual variability in the meso-scale circulation above explained can influence the population dynamics of two of the most important demersal resources of the Mediterranean, the hake and the red shrimp as well as their accessibility to fishing exploitation [34,35].

Some demersal fisheries are developed in the Mallorca Channel, mainly focused on the deep water decapod crustaceans red shrimp (Aristeus antennatus) and the pandalid shrimp Plesionika edwardsi using bottom trawl in the adjacent bottoms of SO and AM and traps at the flanks and summits of the three seamounts, respectively $[9,10]$, where commercial and recreational fishing fleets also operate more sporadically using bottom long-line and handlines, respectively, to capture large sparids and serranids. In all areas, there are also pelagic fisheries, mainly targeted to swordfish (Xiphias gladius) using pelagic and semi-pelagic long-lines [36] and to bluefin tuna (Thunnus thynnus) using purse-seine [37].

\section{Materials and Methods}

We developed a multidisciplinary approach including both geological and biological sampling, monitoring of the fishing fleet, and compilation and review of information from existing databases on fishing landings (Figure 2).

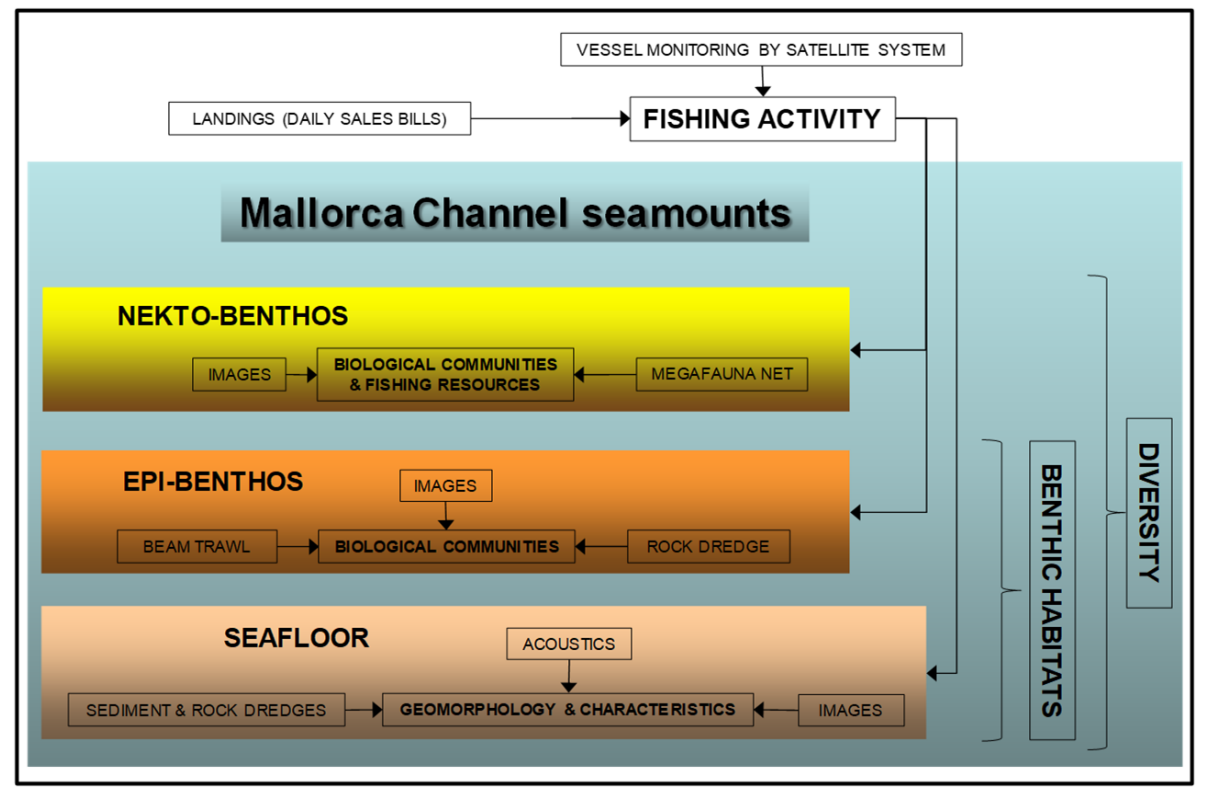

Figure 2. Scheme of the sampling strategy applied during the INTEMARES project in the study of the Ses Olives, Ausias March, and Emile Baudot seamounts of the Mallorca Channel (Balearic Islands, western Mediterranean). 


\subsection{Research Surveys}

Between 2018 and 2020, four INTEMARES research surveys were developed (Table 1). High resolution geophysical techniques were applied to study the seafloor and dredges, where beam trawl and an experimental bottom trawl were used for sampling sediments, rocks, epi-benthic and nekton-benthic organisms as well as demersal fishing resources. A photogrammetric sledge and a remote operated vehicle (ROV) were also used to take videos of the seafloor communities. In 2020 and 2021, samples from the experimental bottom trawl were also collected during the three MEDITS surveys (Table 1).

Table 1. Summary of the research surveys developed in the Ses Olives, Ausias March, and Emile Baudot seamounts and adjacent bottoms of the Mallorca Channel (Balearic Islands, western Mediterranean) during the INTEMARES and MEDITS projects, showing the methods applied to obtain the data and samples: multibeam (MB) and parametric (P) echosounders, Shipek (SK), Box-Corer (BC) and rock (RD) dredges, beam trawl (BT), the experimental bottom trawl GOC-73 (GOC), photogrammetric sledge (ROTV), and remote operated vehicle (ROV).

\begin{tabular}{cccc}
\hline Survey & Period & Research Vessel & Methods \\
\hline INTEMARES_A22B_0718 & 25 July-8 August 2018 & Ángeles Alvariño & MB, P, SK, BC, RD, BT \\
\hline INTEMARES_A22B_1019 & 11-30 October 2019 & Ángeles Alvariño & MB, P, SK, BC, RD, BT, GOC, ROTV \\
\hline MEDITS_ES_GSA5_2020 & 24 June 2020 & Miguel Oliver & GOC \\
\hline INTEMARES_A22B_0720 & 19-29 July 2020 & Ángeles Alvariño & MB, P, RD, BT \\
\hline INTEMARES_A22B_0820 & 21-31 August 2020 & Sarmiento de Gamboa & P, SK, BC, ROV \\
\hline MEDITS_ES_GSA5_2021 & 23 June 2021 & Miguel Oliver & GOC \\
\hline MEDITS-PITIÜSES-2021 & 18, 19 and 25 August 2021 & Miguel Oliver & GOC
\end{tabular}

\subsubsection{Geophysical Methods}

Bathymetric and backscatter data were obtained on board the R/V Angeles Alvariño, which is equipped with a Kongsberg EM710 multibeam echosounder transmitting from 40 to $100 \mathrm{kHz}$, depending on the changes in depth. During the acquisition, a sound velocity correction was applied using sound velocity profiles of the full water column (SVP+ from AML). An area of $4506 \mathrm{~km}^{2}$ has been prospected, from 86 to $1720 \mathrm{~m}$ depths along $3250 \mathrm{~km}$ of parallel navigation lines (Figure 3A) with full coverage. At the same time, ca. $3000 \mathrm{~km}$ of high-resolution parametric profiles were acquired on board R/V Angeles Alvariño and R/V Sarmiento de Gamboa (Figure 3B) using Kongsberg TOPAS PS018 and Atlas Parasound P-35 sub-bottom profilers, respectively. These data allowed us to analyze the geomorphological features of the area.

\subsubsection{Sediments and Rocks}

A total of 137 surface sediment samples were collected using Shipek and Box-Corer grabs between 86 and $1062 \mathrm{~m}$ depths (Figure 3C, Appendix A). Recovered sediments were photographed and described on board. The topmost $5 \mathrm{~cm}$ layer of sediments recovered using the Box-Corer grab were sub-sampled using two sterilized bottles of $50 \mathrm{~g}$ each, which were stored at $-18{ }^{\circ} \mathrm{C}$ for subsequent analysis in the laboratory.

A total of 55 samples were taken using a rock dredge between 89 and $1191 \mathrm{~m}$ depth, mainly at the summit and upper flanks of the seamounts (Figure 3D, Appendix B). This dredge is composed of a metallic rectangular mouth with beveled edges, equipped with a $1 \mathrm{~cm}$ mesh cod-end, protected by another net of $2 \mathrm{~cm}$ meshes and leather covers on bottom and top sides. It was trawled in an upward direction over the seafloor, collecting rock fragments, together with the associated flora and fauna. Sampling was conducted at $0.5-1$ knots, with an effective duration from 5 to $10 \mathrm{~min}$. 

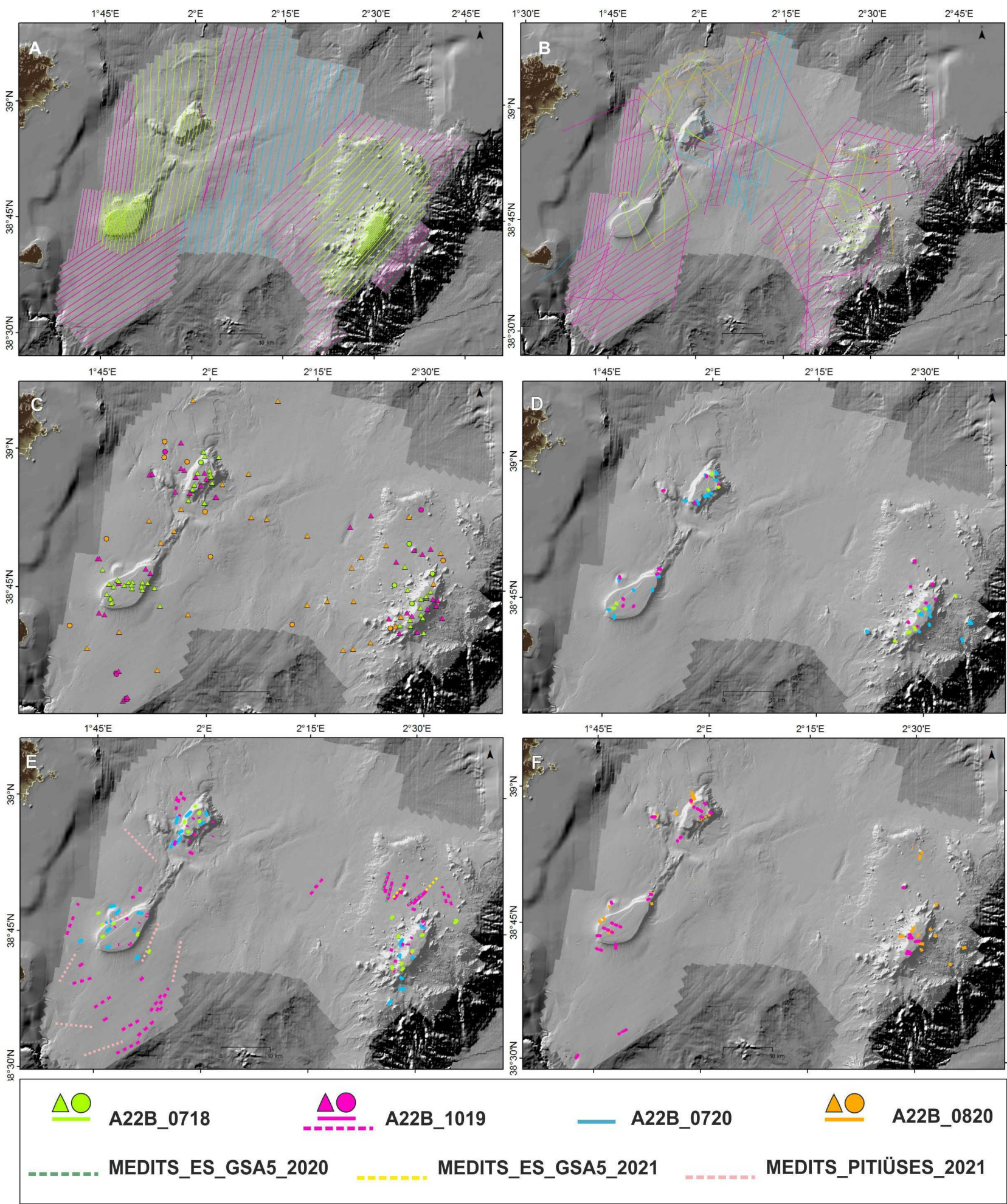

Figure 3. Map of the study area around the Ses Olives, Ausias March, and Emile Baudot seamounts in the Mallorca Channel (Balearic Islands, western Mediterranean) showing the sampling developed in each research survey (plotted in different colors): (A) multibeam echosounder; (B) high-resolution subbottom profilers; (C) Box-Corer in circles and Shipek in triangles; (D) rock dredges; (E) beam trawl (continuous lines) and GOC (dashed lines); and (F) ROTV (dashed lines) and ROV (continuous lines). 


\subsubsection{Epi-benthos}

Samples were collected with a standard beam trawl described by Jennings et al. (1999) [38], and efficiency was estimated by Reiss et al. (2006) [39]. It has horizontal and vertical openings of 2 and $0.5 \mathrm{~m}$, respectively, and a cod-end mesh size of $5 \mathrm{~mm}$. Sampling was conducted at 2 knots and between 5 and 15 min of effective sampling duration. A total of 85 sampling stations were covered between 99 and $764 \mathrm{~m}$ depths (Figure 3E, Appendix C).

The megafauna was sorted on board, identified to species level or to the lowest possible taxonomic level, counted, and weighed. For the calculation of the abundance of colonial ascidians or cnidarians, a foot or colony was counted as one unit or individual. Some species of sponges and algae appeared fragmented and only their biomass was estimated. In the case of calcareous algae, only the biomass of living rhodoliths was measured.

Unidentified specimens were preserved in absolute ethanol or formaldehyde depending on the taxon for further identification at the laboratory. Abundance and biomass of living organisms were standardized by species or taxon to $500 \mathrm{~m}^{2}$ using the horizontal opening of the net and the effective towing distance over the bottom in each haul. This distance was estimated using a global positioning system (GPS) and a SCANMAR net probe attached to the headline of the beam trawl to control depth and its arrival and departure to the bottom.

\subsubsection{Nekto-Benthos and Demersal Resources}

Samples were collected using the experimental bottom trawl GOC-73, widely used along the northern Mediterranean by the MEDITS program to estimate the abundance and distribution of demersal resources and the impact of the fishing activity on the ecosystems [40,41]. This gear has horizontal and vertical net openings ranging 18-22 and 2.5-3 m, respectively, and a cod-end mesh size of $10 \mathrm{~mm}$. Its sampling efficiency has been estimated by Dremière et al. (1999) [42] and Fiorentini et al. (1999) [43]. Sampling was conducted at 2.8 knots and between 45 and 60 min of effective sampling duration, depending on depth. A total of 29 sampling stations were covered between 237 and $1028 \mathrm{~m}$ depths in the adjacent fishing grounds of AM and EB (Figure 3E, Appendix D).

Samples were sorted on board, identified to species level, counted, and weighed following the above-mentioned criteria. Length frequency sampling of fishes, decapod crustaceans, and cephalopod mollusks was also estimated. Abundance and biomass of species were standardized to one square $\mathrm{km}$, using the horizontal opening of the net and the distance covered in each haul, obtained using the SCANMAR system and the GPS, respectively.

\subsubsection{Visual Transects}

Habitat and benthic communities were high resolution filmed from transects developed with the TASIFE photogrammetric sledge, a remotely operated towed vehicle (ROTV), and the ROV Liropus 2000. Each covered a different objective: The ROTV filmed sedimentary and flat areas, while the ROV filmed rockier areas and steeper slopes.

The ROTV transects were carried out with the vehicle moving at 0.5 knots and flying from 0.5 to $2.5 \mathrm{~m}$ above the seafloor. It was equipped with a Nano SeaCam piloting camera installed forward and a Nikon D800 video recording camera in the zenithal position, a spotlight system to illuminate the seafloor and three green laser beams, with a distance between them of 10 and $24 \mathrm{~cm}$. Its accurate location over the bottom was obtained from the HiPAP $^{\circledR}$ acoustic positioning of the R/V. The ROTV was also equipped with a precision altimeter and a SBE50 pressure sensor to control its distance to the bottom and depth, respectively. A total of 48 transects from 15 to 20 min were recorded with a ROTV between 87 and $708 \mathrm{~m}$ depths (Figure $3 \mathrm{~F}$, Appendix E), providing $13 \mathrm{~h}$ of video and a total explored area of 30,066 $\mathrm{m}^{2}: 8304 \mathrm{~m}^{2}$ in SO, 19,124 $\mathrm{m}^{2}$ in AM, and $2638 \mathrm{~m}^{2}$ in EB.

The ROV transects were carried out with the vehicle moving at $<0.3$ knots and flying from 0.5 to $2.5 \mathrm{~m}$ above the seafloor. This ROV is equipped with a full HD color camera and a pal color camera installed forward and a mini camera in the rear part. It was also 
equipped with a CTD SBE37Microcat, two laser pointers, a dual frequency SONAR Seaking DST, an altimeter (LPA200), an acoustic Beacon MST 324, two hydraulic manipulators, and a boxes system to store collected samples. The navigation system of this ROV includes a Tether Management System (TMS) and a Launch and Recovery System (LARS). The TMS is equipped with an extra low light back and white camera, a CTD, a current meter Midas Valeport, and an acoustic beacon MST 324. A total of 29 transects from one to four hours were recorded with ROV between 89 and $1162 \mathrm{~m}$ depth (Figure 3F, Appendix F), providing $52 \mathrm{~h}$ of video and a total explored area of $17,322 \mathrm{~m}^{2}$.

\subsection{Fishing Activity}

The most important demersal fishery operating within the study area was assessed from Vessel Monitoring by satellite System (VMS) data of the bottom trawl fleet. The VMS database consists of records that contain data on the geographic position, date, time, and instantaneous velocity for each boat, approximately every two hours. In the study area, trawlers are only allowed to work 12-13 h per day (05:00-17:00 the insular fleet and 05:00-18:00 the peninsular fleet) and five days a week, from Monday to Friday. In order to remove VMS signals from boats transiting to fishing grounds or ports, only records with an instantaneous vessel velocity from 2 to 3.5 knots were selected, making sure vessels were fishing at the time of the emitted signal.

After filtering, a total of 115,764 VMS signals were retained during the period 20162019. These signals were used to estimate the trawling effort in the study area. Each signal was assigned to one of the trawl fishing grounds previously mapped by Guijarro et al. (2020) [44] around the Balearic Islands. Then, the fishing effort in each fishing ground was calculated as the number of fishing trips per year. In addition, data on the landings and their economic value were obtained from daily sales bills of the bottom trawl fleet. The marketing of their catches takes place the same day or the day after the catches, depending on the ports. These sheets detail, for each vessel, the kilograms auctioned by species commercial category as well as their first sale value. The daily VMS data of the vessels allowed us to assign their sales sheets, and therefore the landings, to the exploited fishing grounds. To assess the bottom trawling around the studied seamounts, we estimated the number of fishing days developed by trawlers in the fishing grounds closest to them as well as the catches extracted and revenues obtained.

\subsection{Analysis of Samples in the Laboratory and Data Processing \\ 3.3.1. Geomorphology}

Bathymetric raw data were imported in a single project using CARIS HIPS and SIPS V. 11.3 software (C) Teledyne) and were georeferenced to create a gridded base surface of a $2 \times 2 \mathrm{~m}$ cell size in the shallower zones of the summit of the seamounts, of $8 \times 8$ $\mathrm{m}$ in the whole seamounts, and $16 \times 16$ in the deepest zones of the seafloor. The CUBE algorithm was used to create the surface and data were manually inspected and cleaned using the subset editor module. Tide correction was applied and the final processed data were exported as geotiff raster files. After cleaning, the backscatter mosaic was obtained using the SIPS backscatter module and Geocoder algorithm and exported as a geotiff raster with the same resolution. Bathymetric and backscatter processed data were integrated into an ArcGIS v.10.8 (@ ESRI) project where the geomorphological analysis was conducted.

Parametric profiles were loaded in a Kingdom IHS Markit software for their interpretation. Time-to-depth conversion was conducted assuming a sound velocity of $1600 \mathrm{~m} / \mathrm{s}$ for unconsolidated sediments [45].

The identification and counting of pockmarks were carried out using a sequence of well-defined ESRI ArcGIS tools for mapping and spatially delineated these features in individual polygons, which represent the areas of the seabed where pockmarks occur. The methodology used was based on the study developed in other pockmark fields located in the central North Sea [46]. 


\subsubsection{Sediments}

The sedimentological analysis for grain size distribution was carried out on 10-15 $\mathrm{g}$ of sediment pre-treated with $10 \% \mathrm{H}_{2} \mathrm{O}_{2}$ to remove organic matter and sodium hexametaphosphate as a dispersing agent. Samples were wet sieved to separate the coarse fraction (gravel) using a $2 \mathrm{~mm}$ mesh size sieve. Particles $<2 \mathrm{~mm}$ (sand, silt, and clay) were determined by using a laser diffraction analyzer (Mastersizer 3000, Malvern ${ }^{\circledR}$ Panalytical, Fuengirola, Spain). The textural classification of the sediments was based on Folk (1954) [47] ternary diagrams.

The organic matter $(\mathrm{OM})$ and carbonate contents were obtained by the loss on ignition method (LOI) [48] in dry sediment samples $\left(60^{\circ} \mathrm{C}\right.$ for $\left.72 \mathrm{~h}\right)$. The percentages of $\mathrm{OM}$ and carbonates were estimated as the weight loss after the first $\left(550{ }^{\circ} \mathrm{C}\right.$ for $4 \mathrm{~h}$ ) and second $\left(950{ }^{\circ} \mathrm{C}\right.$ for $2 \mathrm{~h}$ ) ignitions, respectively.

\subsubsection{Biological Communities and Fishing Resources}

The standardized abundance and/or biomass by species or taxon at each beam trawl and experimental bottom trawl station were used to construct benthic and nekton-benthic species matrices, respectively. In the case of rock dredge stations, for which standardization was not possible, the data matrix only included the presence/absence data by species or taxon. Additionally, the length frequency distribution of the red shrimp Aristeus antennatus, the target fishing resource for the deep-water trawl fishery in the whole western Mediterranean [49], was also estimated from the experimental bottom trawl samples.

For multivariate analysis, data were square-root transformed and similarity between samples was calculated using the Bray-Curtis index. Cluster analysis and non-metric multidimensional scaling (MDS) were conducted to identify assemblages. The similarity percentage analysis (SIMPER) and the analysis of similarity (ANOSIM) were applied to characterize the species composition of assemblages and to test for differences in their composition, respectively.

For each assemblage, we calculated the following community and diversity indicators: mean standardized total abundance and biomass, number of species (S), Shannon-Wiener $\left(\mathrm{H}^{\prime}\right)$, and Pielou evenness $\left(\mathrm{J}^{\prime}\right)$. These analyses were performed with the PRIMER-E 6 and PERMANOVA software [50]. The index of diversity N90, especially sensitive to the fishing impact [51-53], was also applied to detect differences between assemblages. This was calculated following the R procedure described in Farriols et al. (2021) [54]. For statistical comparisons, the Student's $t$-test was used. The Shapiro-Wilk test was applied to check for normality. When this assumption was not met, a Kruskal-Wallis non-parametric test was applied.

\subsubsection{Habitat Identification from Images}

The analysis of video transects carried out thus far has been qualitative. Both ROTV and ROV were viewed using VLC Media Player 3.0.16 for Windows software. Video fragments not allowing for accurate identification of habitats or species, containing blurry images or not showing the two laser pointers, were considered not valid. Video recorded while the ROV stopped or was too far or too close from the seabed to properly visualize it was also considered not reliable for analysis.

In the case of ROTV, the coverage percentage of each habitat type was estimated with the time observed within a width of $0.5 \mathrm{~m}$ (based on the laser beams). The video fragments were divided into sections that showed only one habitat at a constant speed and the same distance from the seafloor. These fragments were considered the sampling units. The covered area was calculated by multiplying the sampling unit length by the field of vision width of the ROV camera, estimated from the laser pointers for scaling.

On each sampling unit, habitat and substrate type categories (fine sand, medium sand to gravel, cobbles and pebbles, rhodoliths, and rock) were defined and the biota was identified to the lowest possible taxonomic level and counted, with special focus on taxa considered vulnerable, as a conservation target and habitat-forming species. In some cases, especially for sponges, cnidarians and tunicates were catalogued in morphotype categories. 
The habitat identification was carried out considering those included in the Habitats Directive 92/43/EEC such as sandbanks that are slightly covered by sea water all the time (Habitat code 1110), reef (Habitat code 1170), and underwater structures formed by gas leaking (Habitat code 1180). When none of these habitats was observed, it was categorized according to the Spanish Inventory of Marine Habitats and Species [55], guidelines for inventorying and monitoring dark habitats in the Mediterranean [56], and previous studies in the Balearic Islands [13,14,57-59].

\section{Results}

\subsection{Geomorphological Features of the Seafloor}

Six main morphological feature groups characterized the geodiversity of the Mallorca Channel (Figure 4). Based on their origin, these features were classified as (i) structural; (ii) fluid escape-related; (iii) volcanic; (iv) mass movement-related; (v) bottom current-related; and (vi) biogenic-related (Figure 4A). The near surface morphology and the sub-bottom sedimentary structure of these features as well as their location in each seamount and adjacent seafloor are explained below.

\section{- $\quad$ Structural features}

Features related to tectonics, with a morphological expression on the seafloor, were mapped in the entire study area. The main structures were seamounts, highs, ridges, tectonic depressions, and fault scarps.

Both SO and AM are NNE-SSW trending seamounts made up sedimentary rocky materials, corresponding to Balearic Promontory basement uplifted by tectonics. A linear fault scarp runs longitudinally across the summit of AM at 86-150 m depth (Figure 4C). It is $8.6 \mathrm{~km}$ long, up to $64 \mathrm{~m}$ deep in its SW edge and $23 \mathrm{~m}$ in its NE edge, with $32^{\circ}$ of slope (Figure $4 \mathrm{~B})$. The sub-bottom profiles indicated a relatively thin sedimentary cover $(<15 \mathrm{~m})$ at the summits of the seamounts (Figure $4 \mathrm{~F}$ ).

Close to these seamounts, two minor highs named Greixonera and Dimoni are located, showing sharp flanks up to $40^{\circ}$ of slope (Figure 4D). Greixonera, $230 \mathrm{~m}$ high and $6 \mathrm{~km}$ long, is located in western SO, whilst Dimoni is a $300 \mathrm{~m}$ high and $5 \mathrm{~km}$ long spike located at the edge of a structural spur in northern AM.

Moreover, two NE-SW ridges were located to the north and central area of the Mallorca Channel, having lengths of 10 to $12 \mathrm{~km}$, respectively, and moderate slopes (Figure 4A,B). Several depressions and fault scarps with NNE-SSW to N-S trends are located to the northeast of the northern ridge, and to the north, south, and east of the central ridge, most likely associated with structural control.

\section{- $\quad$ Fluid escape-related features}

Pockmarks are the main feature related to fluid seepage, being mapped more than 3950 in a 300-1000 m depth range. They are extended in the whole study area, with the exception of the deep central basin area, which only presents some individual depressions. Most of these pockmarks had circular shapes with U to V-shaped cross sections (Figure 4D). Their length ranged from 10 to $500 \mathrm{~m}$ and up to $40 \mathrm{~m}$ in deep. Although most of them appeared randomly distributed, some were aligned, forming strings in mainly NW-SE, NE-SW, and N-S trends. In some cases, these strings developed elongated depressions and were emplaced on normal faults, recognized in the parametric profiles (Figure 4G).

\section{- Volcanic features}

The main volcanic element is the EB seamount that corresponds to a NNE-SSW oriented volcanic guyot, whose summit is located between 94 and $150 \mathrm{~m}$ in depth. It is constituted by the coalescence of several volcanic buildings, partially visible on the eroded summit of the seamount, which is also characterized by several terraced levels at 100-150 m depth and a volcanic cone of $130 \mathrm{~m}$ high in its northeastern edge.

In addition, a volcanic cone field was identified on the flanks and adjacent seafloor of EB between 215 and $915 \mathrm{~m}$ depths (Figure 4A,E). It comprises at least 170 spike and 
flat-topped conical edifices that rise from 25 to $420 \mathrm{~m}$, with maximum widths and lengths of 140 to $1785 \mathrm{~m}$ and slopes up to $50^{\circ}$. These are mostly circular, although some have irregular geometries.

- Mass-movement related features

Mass-movement features were one of the most widespread features in the Mallorca Channel. They comprise both erosive and depositional elements such as slide scars and mass-transport deposits (MTD). In addition, some gullies related to these features have been differentiated.

Erosive surfaces and gullies developed in the upper sector of the eastern flanks of EB and AM, forming a network of drainage that erodes their walls. They appear as narrow $\mathrm{V}$ incisions, separated by moderate to sharp ridges up to $30 \mathrm{~m}$ in depth. They have different orders of magnitude, being larger in EB than in AM. In general, they are 1 to $5 \mathrm{~km}$ long and have NW-SE and NE-SW to N-S trends, respectively (Figure 4C), with moderate slopes. Their heads are mainly sub-circular in shape and coalesce, forming major amphitheater scarps such as the one located northwestern EB, up to $4 \mathrm{~km}$ long (Figure 4C).

Slide scars were identified on the eastern flanks of SO and the western flank of EB as well as in the adjacent seafloor (Figure $4 \mathrm{~A}, \mathrm{E}$ ). They have amphitheater geometry and high slopes of $40^{\circ}$, lengths of 1.5 to $2.2 \mathrm{~km}$ in SO, and up to $5 \mathrm{~km}$ long in EB. Those developed in the northern Mallorca Channel are evenly affected by pockmarks at the sharp walls.

MTDs were present along the Mallorca Channel slope, mainly at the foot of the slope of the seamounts at different depths, generating scarps of up to $20 \mathrm{~m}$ high at the seafloor. In parametric profiles, it was observed that most part of these deposits has nowadays been buried, but recent deposits affecting the seabed were also observed. Those MTDs were up to $50 \mathrm{~m}$ thick and recognized by the disappearance of sediment packages and the presence of sedimentary features. Moreover, some buried MDTs appeared stacked, representing at least three different events (Figure 4G).

- Bottom current related features

Bottom current features were mainly mapped at the base of AM. They comprised erosive elements such as contourite moats and furrows and depositional ones such as contourite drifts and sediment waves.

Contourite moats were elongated depressions located around seamounts. They are asymmetric and have U-shaped cross sections that deepen up to $30 \mathrm{~m}$ of incision and are mainly NE-SW oriented. In addition, a major $2 \mathrm{~km}$ long and $35 \mathrm{~m}$ deep moat was identified locally, associated with the western edge of AM. It is asymmetric, half-moon shaped, and NE-SW oriented (Figure 4C).

Several contourite drifts were identified associated with the moats, depressions, and the seamounts. These are mainly mounded and plastered drifts attached to the edges or bases of these features. These contourite drifts are occasionally disturbed by pockmarks and slide scars, and in some cases, older MTDs appear under the youngest drift deposits (Figure 4F).

Small scale sediment waves were identified in the southern AM at 300-400 m depths. They comprise slightly sinuous crests with NE-SW to N-S trends and occupy a total area of $17 \mathrm{~km}^{2}$ (Figure $4 \mathrm{C}, \mathrm{H}$ ).

- $\quad$ Biogenic related features

Biogenic features were identified in the summits and upper flanks of SO, AM, and $\mathrm{EB}$, being well represented in the western area of AM and central area of EB. They are mound-shaped to ridge features up to 2 to $15 \mathrm{~m}$ high and around $200 \mathrm{~m}$ long, that when coalesced reach lengths up to $1 \mathrm{~km}$ (Figure 4A,D). Biogenic mounds were formed by hard substrates, coming from bioclastic accumulations of fossil and contemporary calcareous framework-building organisms such as coralline algae (e.g., rhodoliths) and other skeletonsupported reefs of scleractianians and octorals as well as bivalve cement-supported reefs. 


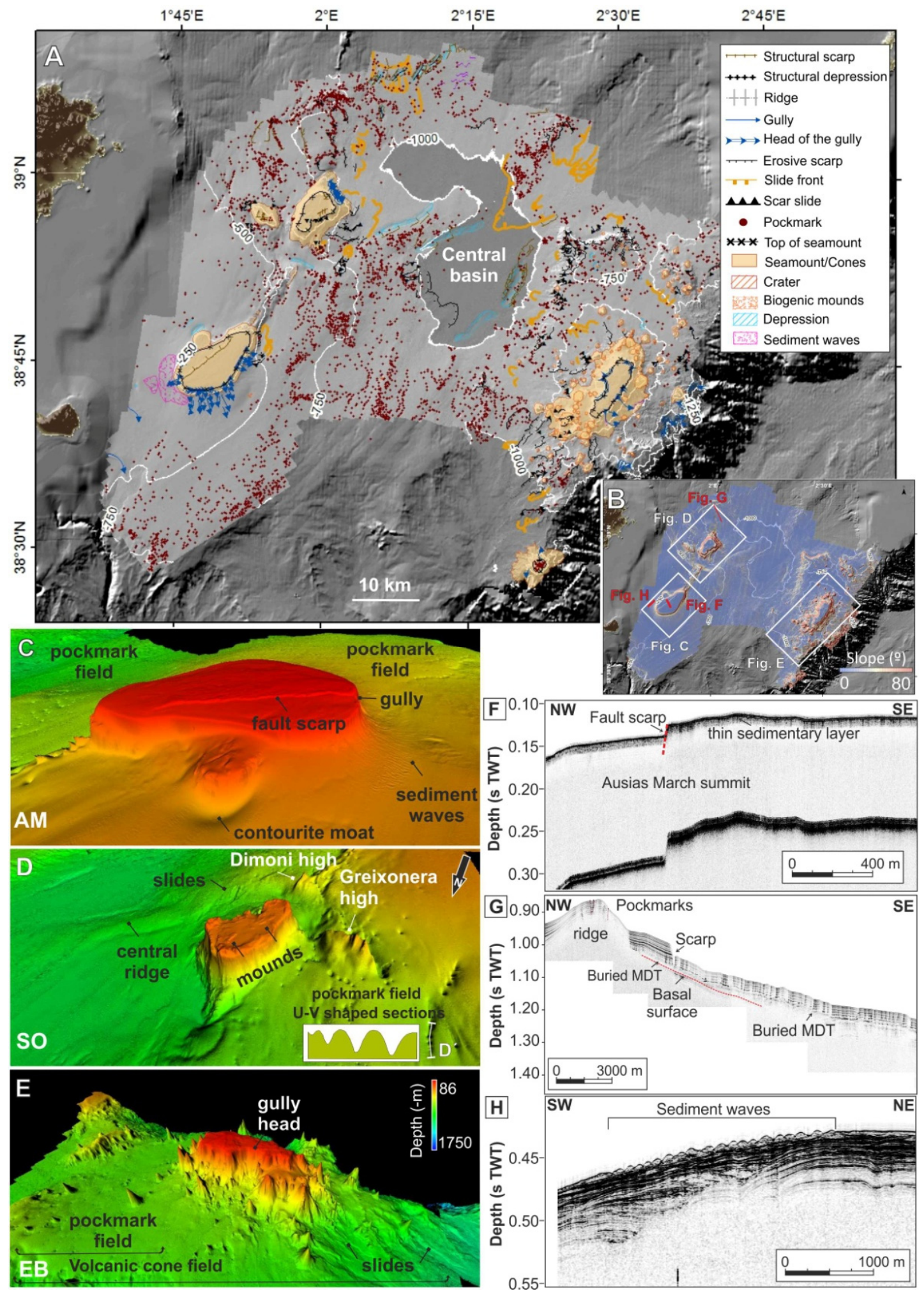

Figure 4. Bathymetry and geomorphology of the seafloor in the Mallorca Channel: (A) Morphological map showing the main morphological features and domains of the study area; (B) slope map showing bathymetric contours at each $250 \mathrm{~m}$ and the location of the 3D bathymetric models and parametric profiles; (C-E) overview 3D bathymetric map of the main edifices of the study area: Ses Olives, Ausias March, and Emile Baudot seamounts and Greixonera and Dimoni highs; $(\mathbf{F}-\mathbf{H})$ parametric profiles showing the internal structure of the main morphological features present in the study area. 


\subsection{Sediment Characterization}

Sediments at the summit of AM were coarse and mixed (Figure 5A,B) with a texture ranging from gravelly sand (up to $35 \%$ gravel) to gravelly muddy sand (up to $28 \%$ mud). The nearest surrounding areas of this seamount were muddy to silty sand (up to $36 \%$ silt), evolving to a finer texture of sandy silt (up to $61 \%$ silt) toward the Dimoni high. The pockmark field at the southern area of the seamount was mostly sandy mud to sandy silt (53\% average silt), with 22 and $25 \%$ clay and sand content, respectively (Figure 5A,B).

Sediments at the summit of SO show an average sand content of $90 \%$, thus they were classified as sand and muddy sand becoming less sandy ( $68 \%$ on average) and more muddy $(32 \%)$ toward the flanks (Figure 5A,B). The pockmark field observed at the northwest of this seamount was sandy mud in texture, where the silt content ( $40 \%$ on average) was higher than the clay (23\%) and the sand (37\%).

EB was quite heterogeneous in sediment texture, ranging from coarse sediments of gravelly sand (up to $92 \%$ sand) and mixed sediments of gravelly mud (up to $83 \%$ mud) at the summit, toward sand (up to $98 \%$ ) to muddy sand (up to $48 \%$ mud) in some areas of the summit, the flanks, and in the nearest area of volcanic cones (Figure 5A,B). The pockmark field at the north of this seamount is sandy mud that evolves to coarser sediment, predominantly muddy sand toward northern areas. On average, the sediment was characterized by 42,36 , and $22 \%$ of sand, silt, and clay, respectively.

A
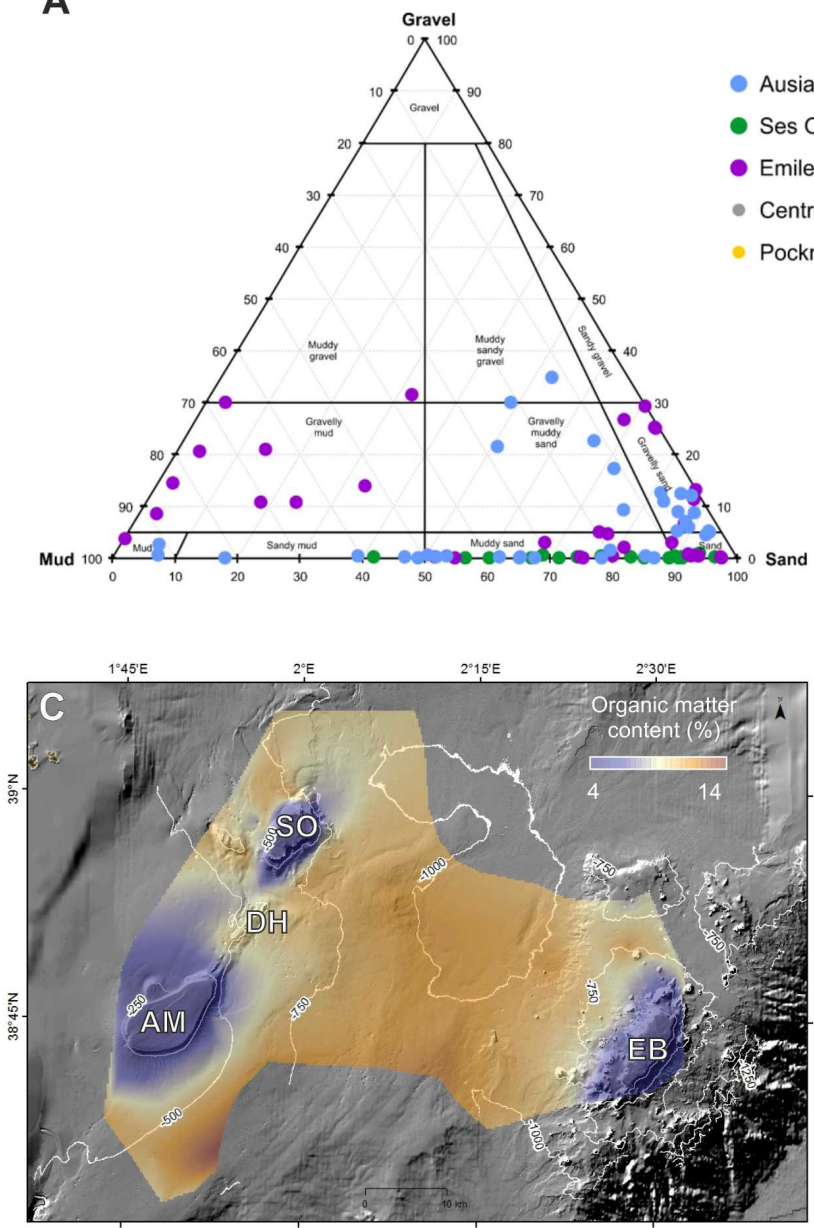

B

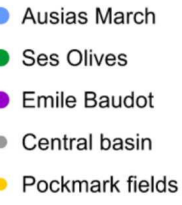

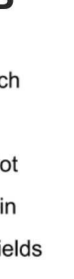
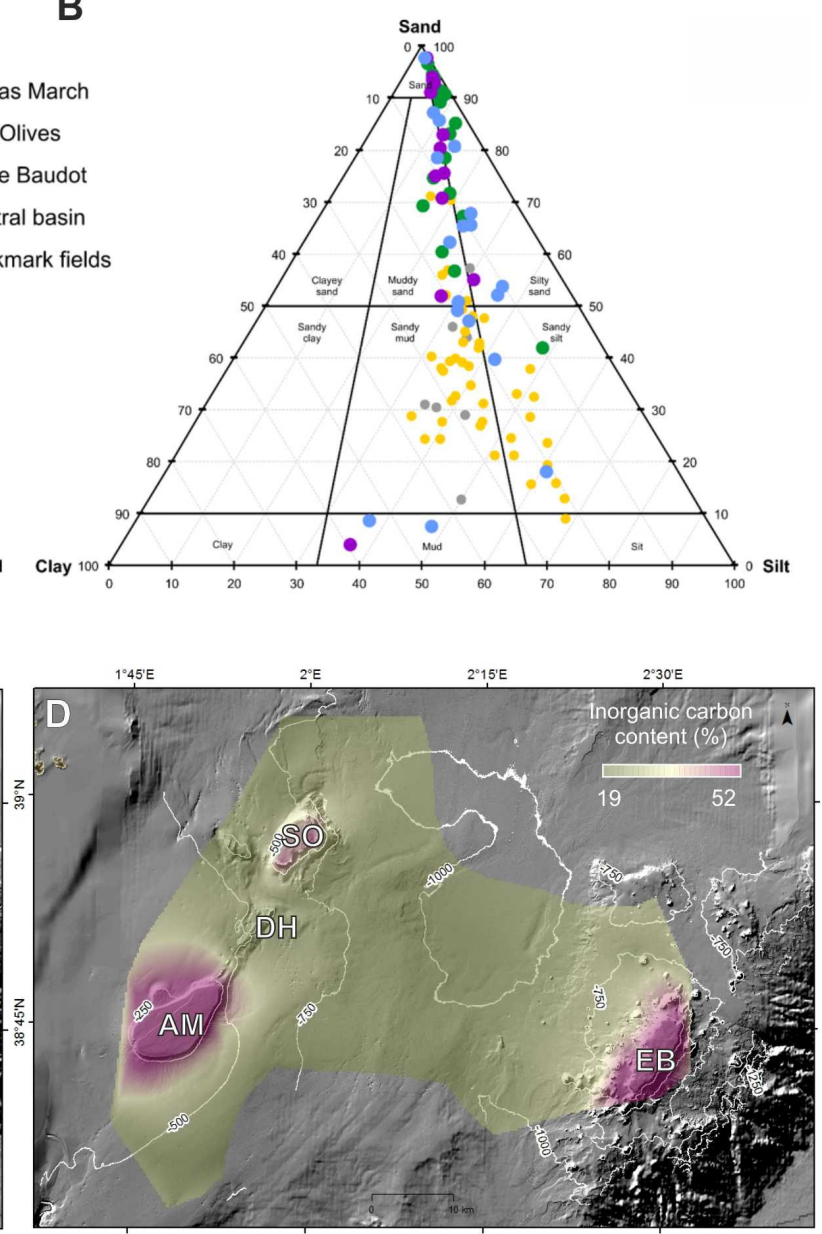

Figure 5. Surface sediment characteristics of the Ses Olives, Ausias March, and Emile Baudot seamounts, pockmark fields around them, and the central basin of the Mallorca Channel (Balearic Islands, western Mediterranean): (A,B) Folk (1954) classification diagrams indicating the particle size percentage variation of the surface sediment samples; $(\mathbf{C})$ organic matter content percentage map; and (D) inorganic carbon content percentage map. 
In general, the coarser sediments were observed in the summit of AM, followed by EB and SO. The main difference among the pockmark fields is the content of silt and sand, since the clay was similar in all of them. The coarser textures were observed in the pockmark field in northern EB, while the finer textures were present in the pockmark field in southern AM. Some samples in the central basin showed sediments of sandy mud texture (Figure 5A,B), with silt (up to $50 \%$ ) as the dominant fine fraction.

The organic matter content in surface sediments ranged from 4 to $14.3 \%$ with a mean value of $10.4 \%$ (Figure 5C). The lowest values (4.6-9.3\%) were observed on the summits of the three seamounts, extending along their flanks to 300-350 m depths. The rest of the studied area showed intermediate to high values of organic matter content (9.3-14.3\%), with the highest values observed in the central basin.

The carbonate (inorganic carbon) content values of the surface sediments ranged from 19.5 to $52.2 \%$, with an average value of $27.9 \%$ (Figure 5D). The spatial distribution showed maximum values ( $>43 \%$ ) at the summits of $A M$ and EB, extending on their flanks up to $250 \mathrm{~m}$ in depth. In general, the distribution was opposite to that of the organic matter content. The intermediate values (43-34\%) were distributed from 250 to $350 \mathrm{~m}$ depths including the summit of SO. The rest of the studied area, from a $350 \mathrm{~m}$ depth onward, was covered by sediments with low carbonate content $(<34 \%)$, reaching minimum values in the central basin.

\subsection{Biodiversity, Species Assemblages and Fishing Resources}

So far, a total of 547 different species or taxa have been identified (Appendix $G$ ), most of them identified from beam trawl (68\%), while 30, 29, and 25\% were identified from $\mathrm{ROV}$, bottom trawl, and rock dredge sampling, respectively. There were also differences in the number of species or taxa identified by seamount, being 184 in SO, 413 in AM, and 369 in EB. The more diverse groups were sponges, followed by teleost fishes, mollusks, crustaceans, and echinoderms with 118 (22\%), 105 (19\%), 96 (18\%), 91 (17\%), and 49 (9\%) species or taxa identified, respectively.

The cluster and MDS analyses of standardized biomass from beam trawl samples identified three epi-benthic assemblages on sedimentary bottoms, which were strongly influenced by depth (Figure 6A): (BT-a) the shallowest samples, between 102 and $169 \mathrm{~m}$, at the summits of AM and EM; (BT-b) a group of samples from intermediate depths, between 227 and $574 \mathrm{~m}$, at the summit of SO and flanks of SO, AM, and EB; and (BT-c) the deepest samples, between 500 and $756 \mathrm{~m}$, at the base and adjacent bottoms of these three seamounts. The ANOSIM results $(\mathrm{R}=0.77 ; p<0.01)$ confirmed significant differences between these assemblages. The mean values for the estimated ecological parameters showed differences between these assemblages (Table 2). Both standardized abundance and biomass and the diversity indices $S, H^{\prime}$, and $\mathrm{N}_{90}$ decreased with depth. In contrast, the three assemblages showed similar values of equitability $\left(\mathrm{J}^{\prime}\right)$. 

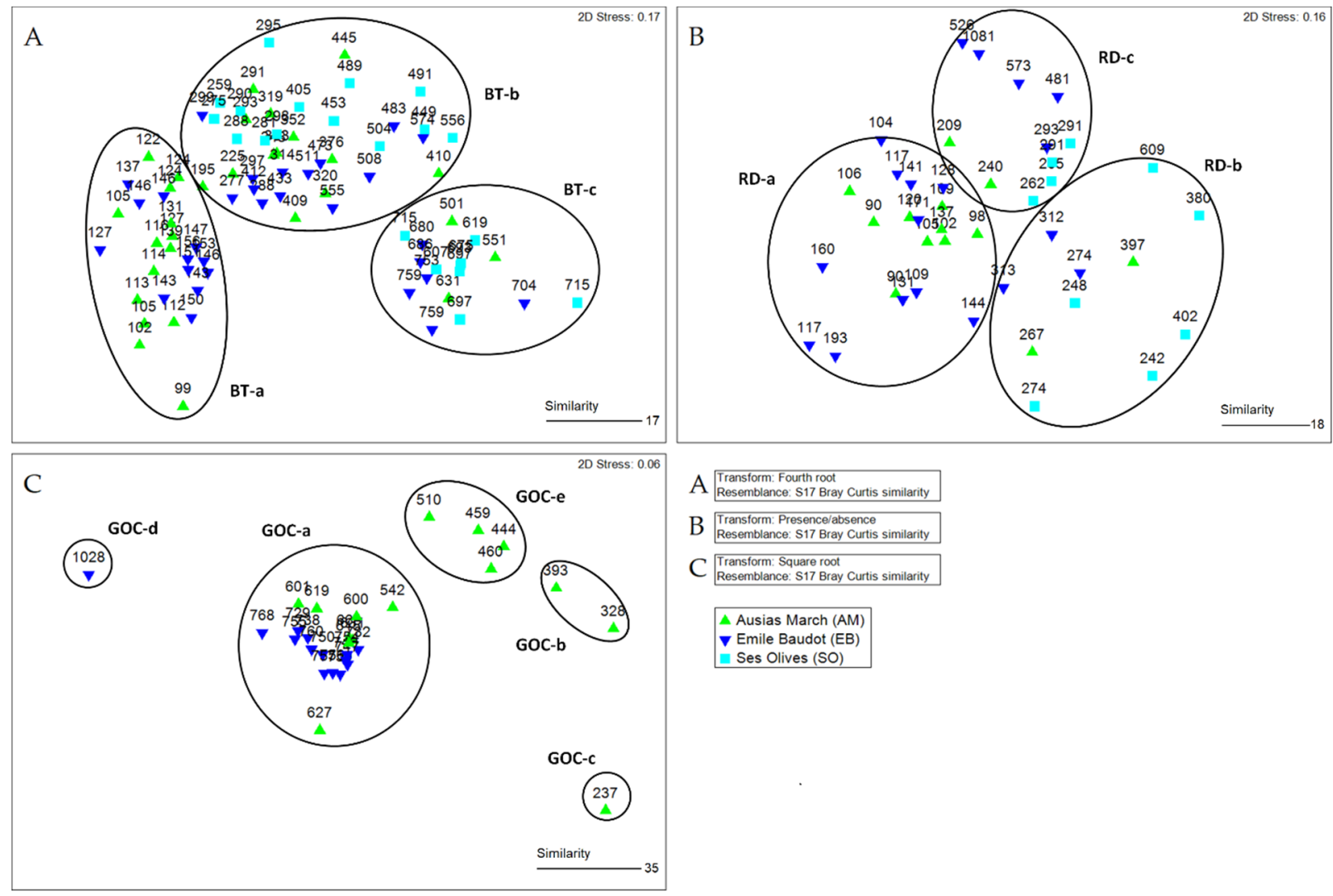

C $\begin{aligned} & \text { Transform: Square root } \\ & \text { Resemblance: S17 Bray Curtis similarity }\end{aligned}$

$\triangle$ Ausias March (AM)

V Emile Baudot (EB)

Ses Olives (SO)

Figure 6. Multi-variant analysis of benthic assemblages, obtained in sedimentary and rocky bottoms of the Ses Olives (SO), Ausias March (AM) and Emile Baudot (EB) seamounts and adjacent area of the Mallorca Channel (Balearic Islands, western Mediterranean): (A) MDS and clusters at $>17 \%$ similarity of epi-benthic species, identified from the analysis of beam trawl samples, in terms of standardized biomass $\left(\mathrm{g} / 500 \mathrm{~m}^{2}\right)$, obtained in sedimentary bottoms; (B) MDS and clusters at $>18 \%$ similarity of benthic species assemblages, identified from the analysis of presence/absence matrix from rock dredge samples, obtained in rocky bottoms; and (C) MDS and clusters at $50 \%$ similarity of necto-benthic species, identified from the analysis of experimental bottom trawl samples, in terms of standardized abundance (individuals $/ \mathrm{km}^{2}$ ), obtained in the fishing grounds adjacent to AM and EB. Labels and symbols correspond to sampling depth and area, respectively. 
Table 2. Mean values $(\mu)$ and standard errors (SE) of standardized abundance and biomass, species richness $(\mathrm{S})$, Shannon-Wiener $\left(\mathrm{H}^{\prime}\right)$, and Pielou evenness $\left(\mathrm{J}^{\prime}\right)$, estimated for each of the assemblages identified from multi-variant analysis of beam trawl, rock dredge, and experimental bottom trawl samples obtained at the Ses Olives, Ausias March, and Emile Baudot seamounts and adjacent area of the Mallorca Channel (Balearic Islands, western Mediterranean). The code (see Figure 7), number of samples analyzed (n), depth (D), number of species (Spp.) of each assemblage, and the significant differences (Kruskal-Wallis test; $p<0.001$ ) between all assemblages $\left(^{*}\right)$ or between pairs of assemblages $(1-2,1-3)$ are also shown. In the case of beam trawl sample assemblages, mean (AvN $\left.\mathrm{N}_{90}\right)$ and standard deviation $\left(\mathrm{SDN}_{90}\right)$ values of the N90 diversity index are also shown, jointly with the associated average (AvSim) and the standard deviation (SDSim) values of within-group similarity.

\begin{tabular}{|c|c|c|c|c|c|c|c|c|c|c|c|c|c|c|c|c|c|}
\hline \multirow[b]{2}{*}{ Code } & \multirow[b]{2}{*}{$\mathbf{n}$} & \multirow[b]{2}{*}{$\mathrm{D}(\mathrm{m})$} & \multirow[b]{2}{*}{ Spp. } & \multicolumn{2}{|c|}{$\mathrm{n} / 500 \mathrm{~m}^{2}$} & \multicolumn{2}{|c|}{$\mathrm{g} / 500 \mathrm{~m}^{2}$} & \multicolumn{2}{|c|}{$\mathrm{S}$} & \multicolumn{2}{|c|}{$\mathrm{H}^{\prime}$} & \multicolumn{2}{|c|}{$\mathrm{J}^{\prime}$} & \multirow[b]{2}{*}{ AvN90 } & \multirow[b]{2}{*}{ SDN90 } & \multirow[b]{2}{*}{ AvSim } & \multirow[b]{2}{*}{ SDSim } \\
\hline & & & & $\mu$ & SE & $\mu$ & SE & $\mu$ & SE & $\mu$ & SE & $\mu$ & SE & & & & \\
\hline \multicolumn{18}{|c|}{ Beam trawl (BT) } \\
\hline BT-a1 & 25 & 99-156 & 407 & $33(*)$ & 7 & $208.6(1,3)$ & 69.2 & $52.0\left(^{*}\right)$ & 16.2 & $2.6(1,3)$ & 0.7 & 0.7 & 0.2 & 45.62 & 1.08 & 11.43 & 0.48 \\
\hline BT-b2 & 40 & $195-574$ & 354 & $10.3(*)$ & 1.4 & $16.8(1,2)$ & 4.8 & $38.9\left(^{*}\right)$ & 16 & 2.2 & 0.5 & 0.6 & 0.2 & 28.48 & 0.98 & 11.53 & 0.42 \\
\hline BT-c3 & 17 & $501-759$ & 124 & $3.4\left(^{*}\right)$ & 0.9 & 9.7 & 2.8 & $20.5\left(^{*}\right)$ & 7.2 & 1.9 & 0.6 & 0.6 & 0.2 & 8.71 & 0.59 & 21.88 & 0.88 \\
\hline \multicolumn{18}{|c|}{ Rock dredge (RD) } \\
\hline RD-a & 20 & 90-193 & 139 & & & & & 15.15 & 2.11 & & & & & & & & \\
\hline RD-b & 12 & $242-609$ & 64 & & & & & 8.25 & 1.55 & & & & & & & & \\
\hline RD-c & 10 & 209-1081 & 56 & & & & & 9.8 & 1.9 & & & & & & & & \\
\hline \multicolumn{18}{|c|}{ Experimental bottom trawl (GOC) } \\
\hline GOC-a & 21 & $542-768$ & 76 & $3.5 \times 10^{3}$ & 485.4 & 270.5 & 45.2 & 22 & 0.8 & 2.3 & 0 & 0.8 & 0 & & & & \\
\hline GOC-b & 4 & $444-510$ & 66 & $15.1 \times 10^{3}$ & 3283.1 & 206.9 & 73.8 & 41.3 & 2.4 & 2.9 & 0.3 & 0.7 & 0.1 & & & & \\
\hline GOC-c & 2 & $328-393$ & 60 & $44.8 \times 10^{3}$ & $20,958.7$ & 1157 & 427.6 & 42 & 2 & 2.3 & 0.1 & 0.6 & 0 & & & & \\
\hline GOC-d & 1 & 237 & 25 & $6.3 \times 10^{3}$ & - & 749.2 & - & 25 & - & 2 & - & 0.6 & - & & & & \\
\hline
\end{tabular}



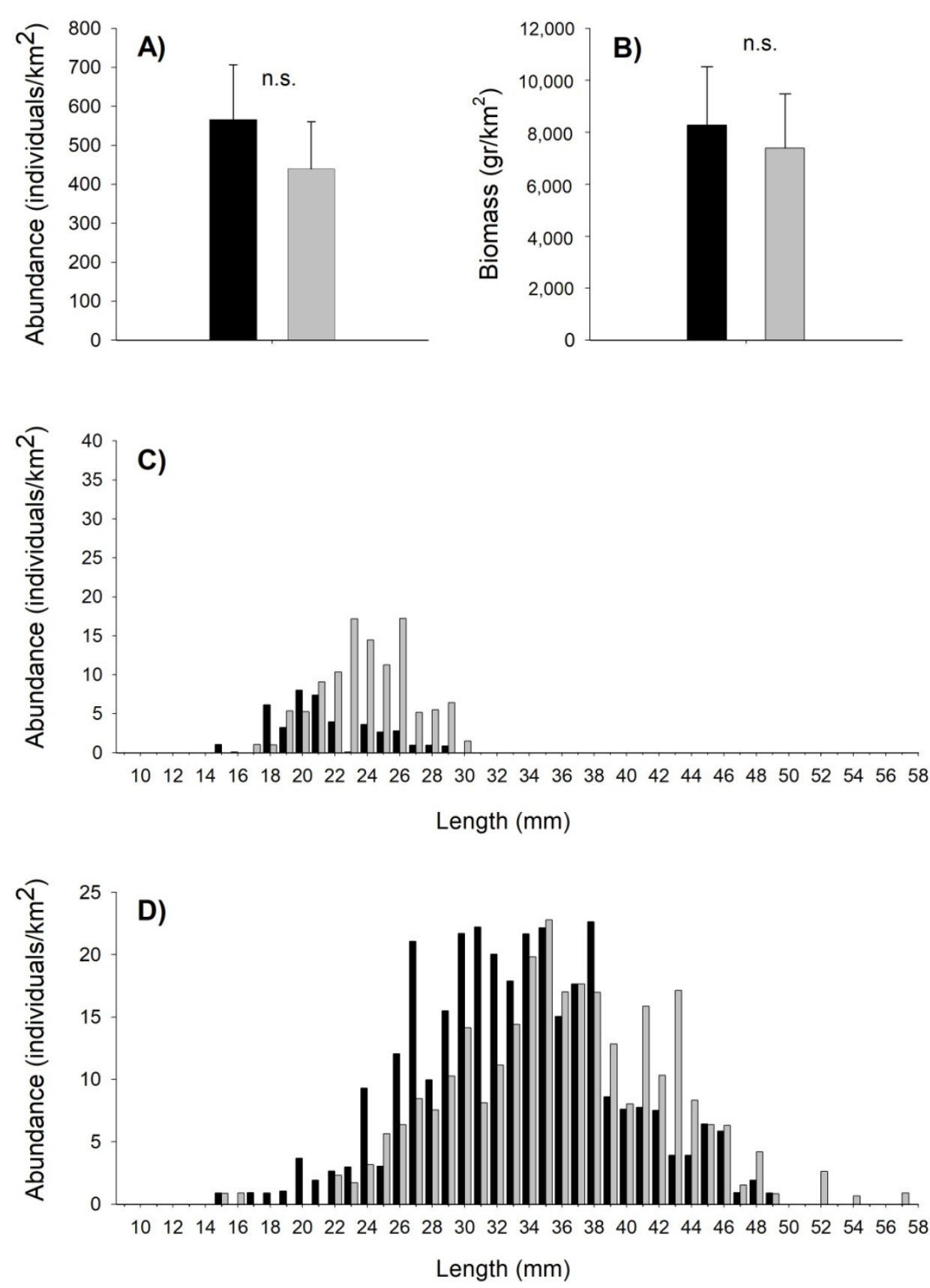

Figure 7. Mean standardized abundance (A) and biomass (B) and length frequency distribution by males (C) and females (D) of red shrimp (Aristeus antennatus) at fishing grounds adjacent to the Ausias March (black columns) and Emile Baudot (grey columns) seamounts of the Mallorca Channel (Balearic Islands, western Mediterranean). Standard error and results of the Student's $t$-test are also shown: n.s. (not significant).

SIMPER results (Table 3; Appendix H) showed that the main species contributing to within-group similarity in the BT-a assemblage were coralline red algae $(10 \%)$, while the contribution of a high number of decapod crustaceans, sponges, brachiopods, and echinoderms, both sea urchins and sea stars, was much lower (1-3\%). No species contributed much more than the others to the similarity of the BT-b assemblage, ranging between 2 and $7 \%$ of the contribution of ten species of crustaceans (decapods and the peracarid Lophogaster typicus), sponges, the brachiopod Gryphus vitreus, an echinoderm (the brittle star Ophiura (Dictenophiura) carnea), and the cephalopod mollusk Sepietta oweniana. Decapod crustaceans were the main species contributing to similarity of the BT-c assemblage, with only three 
species (Geryon longipes, Polycheles typhlops, and Calocaris macandreae) summing more than $50 \%$ of this similarity.

Table 3. Summary of SIMPER results of the assemblages (see codes in Figure 7) identified from multi-variant analysis of beam trawl (BT), rock dredge (RD), and experimental bottom trawl (GOC) samples obtained in sedimentary and rocky bottoms of the Ses Olives (SO), Ausias March (AM), and Emile Baudot (EB) seamounts and adjacent area of the Mallorca Channel (Balearic Islands, western Mediterranean), showing the percentage of within-group similarity (Sim) and the number of species (Spp.) contributing up to $90 \%$ to this similarity. The percentage of between-group dissimilarity (Diss) comparing geographic differences (by seamount) in the identified beam trawl sample assemblages as well the number of species (Spp.) contributing up to $90 \%$ to this dissimilarity, is also shown.

\begin{tabular}{cccccc}
\hline Codes & Sim & Spp. & Areas & Diss & Spp. \\
\hline BT-a & 24.0 & 64 & AM vs. EB & 79.3 & 230 \\
\hline BT-b & 21.9 & 59 & SO vs. AM & 79.7 & 144 \\
& & & SO vs. EB & 79.3 & 171 \\
& & & AM vs. EB & 78.7 & 170 \\
\hline BT-c & 33.3 & 16 & SO vs. AM & 67.7 & 64 \\
& & & SO vs. EB & 67.4 & 68 \\
& & & AM vs. EB & 70.5 & 53 \\
\hline RD-a & 23.4 & 13 & & & \\
\hline RD-b & 23.6 & 7 & & & \\
\hline RD-c & 15.4 & 8 & & & \\
\hline GOC-a & 57.1 & 13 & & \\
\hline GOC-b & 52.1 & 24 & & \\
\hline GOC-c & 53.4 & 14 & & \\
\hline
\end{tabular}

The geographic differences (by seamount) were also analyzed. SIMPER results (Table 3; Appendix H) showed an average dissimilarity of $79.3 \%$ between AM and EB summit samples, being coralline red algae and sponges (e.g., Hexadella sp.), both more abundant in $\mathrm{AM}$, as the species with a higher contribution to this dissimilarity. The average dissimilarity values by comparing SO summit and flanks of the three seamount samples were $79 \%$ in all cases, being G. vitreus and Desmacella inornata, with larger biomass in AM and EB, respectively, the main species that contribute to this dissimilarity. The comparison of samples obtained in the base and adjacent bottoms of the seamounts showed lower values of dissimilarity: $67.7 \%$ (SO-AM), 67.4\% (SO-EB), and 70.5\% (AM-EB). The presence of Isidella elongata at SO and the higher abundance of the fishes Nezumia aequalis and Lepidorhombus boscii at AM and G. vitreus and G. longipes at EB contributed mostly to this dissimilarity.

The cluster and MDS analysis of the presence/absence matrix from the rock dredge also identified three benthic assemblages on rocky bottoms (Figure 6B): (RD-a) the shallowest samples between 90 and $193 \mathrm{~m}$ depths at EM and AM summits; (RD-b) samples from 242 to $609 \mathrm{~m}$ depths at SO, AM, and EB flanks; and (RD-c) a more heterogeneous group, between 240 and $1081 \mathrm{~m}$ depths, at the flanks of the three seamounts and volcanic cones surrounding EB. The ANOSIM results $(\mathrm{R}=0.64 ; p=0.001)$ confirmed significant differences between these assemblages. SIMPER results (Table 3; Appendix H) showed that main species contributing to within-group similarity of the RD-a assemblage were coralline red algae and the brachiopods Megerlia truncata and Argyrotheca cordata, summing up to $70 \%$ of similarity. The decapod crustaceans of the genus Plesionika (three species summing up to $45.7 \%$ ) and the bivalve mollusk Asperarca nodulosa (31\%) were the main species in the RD-b assemblage. The sponges Haliclona poecillastroides, Hamacantha (Hamacantha) sp. 1, Ancorinidae sp. 1, Poecillastra compressa, and other not identified sponges, summed up to $77.5 \%$ of similarity of the RD-c assemblage. 
The cluster and MDS analysis of standardized abundance from the experimental bottom trawl GOC samples on the deep water trawl fishing grounds adjacent to the seamounts identified an assemblage between 542 and $768 \mathrm{~m}$ in depth at AM and EB (GOCa), which is clearly separated from four samples at 444 and $510 \mathrm{~m}$ depth in AM (GOC-b), the two samples at 328 and $393 \mathrm{~m}$ depth in AM (GOC-c), and the shallowest and deepest samples at a $237 \mathrm{~m}$ depth in AM (GOC-d) and at a $1028 \mathrm{~m}$ depth in EB (GOC-e), respectively (Figure 6C). The ANOSIM results $(\mathrm{R}=0.71 ; p<0.01)$ confirmed significant differences between these assemblages. The mean values for the ecological parameters analyzed also showed differences between these assemblages (Table 2). While standardized abundance and the species richness (S) clearly decreased with depth, the standardized biomass and the other diversity indices $\mathrm{H}^{\prime}$ and $\mathrm{J}^{\prime}$ did not show this trend. In the GOC-a assemblage, the ANOSIM results showed low geographic differences between AM and EB $(\mathrm{R}=0.24$, $p<0.002$ ). The dissimilarity between AM and EB in this group was $42.16 \%$ and the main species that contributed to this dissimilarity were the elasmobranch Galeus melastomus $(7.9 \%)$ and the decapod crustaceans Aristeus antennatus (6.8\%), Geryon longipes (5.9\%), and Phasiphaea multidentata (5.3\%).

The SIMPER results (Table 3; Appendix H) showed that the main species contributing to within-group similarity in the GOC-b assemblage were decapod crustaceans, teleost fishes, and one cephalopod mollusk, some of them of commercial interest: Plesionika martia, Nephrops norvegicus, Parapenaeus longirostris, Phycis blennoides, Helicolenus dactylopterus, Lepidorhombus boscii, and Merluccius merluccius. The main species that contributed to withingroup similarity in the GOC-a assemblage were also decapod crustaceans, teleost fishes, and the elasmobranch G. melastomus. Some of these species (P. martia, Hymenocephalus italicus, $P$. blennoides, and Hoplostethus mediterraneus) were the same as the previous assemblage, but contributed with different percentages. Species of commercial interest also contributed to the similarity of the GOC-a assemblage: the target $A$. antennatus and its by-catch $P$. martia, G. longipes, G. melastomus, and P. blennoides.

The data obtained from the experimental bottom trawl GOC-37 samples from 542 to $768 \mathrm{~m}$ in depth at AM and EB allowed us to compare the density and population structure of red shrimp (A. antennatus) between the two fishing grounds adjacent to these seamounts (Figure 7). No significant differences were detected in the standardized abundance and biomass. However, length frequency distributions showed larger males in EB and smaller females in EB.

\subsection{Bottom Trawling}

In recent years, three different trawl fleets operate in the identified three fishing grounds around Ibiza and Formentera Islands, possibly impacting the SO and AM seamounts (Figure 8A): (i) up to nine local vessels from the ports of Sant Antoni de Portmany, Eivissa, and La Savina that focus their activity mainly on the continental shelf; (ii) up to 29 vessels from the ports of Denia, Calp, Altea, La Vila Joiosa, and Santa Pola on the Iberian Peninsula, that can carry out trips of 3-5 days to fish below $150 \mathrm{~m}$ depth; and (iii) only three vessels from the port of Andratx on Mallorca, that carry out daily trips to fish sporadically on the northern slope off Ibiza Island. In contrast, no trawling activity has been detected in adjacent bottoms of EB. 


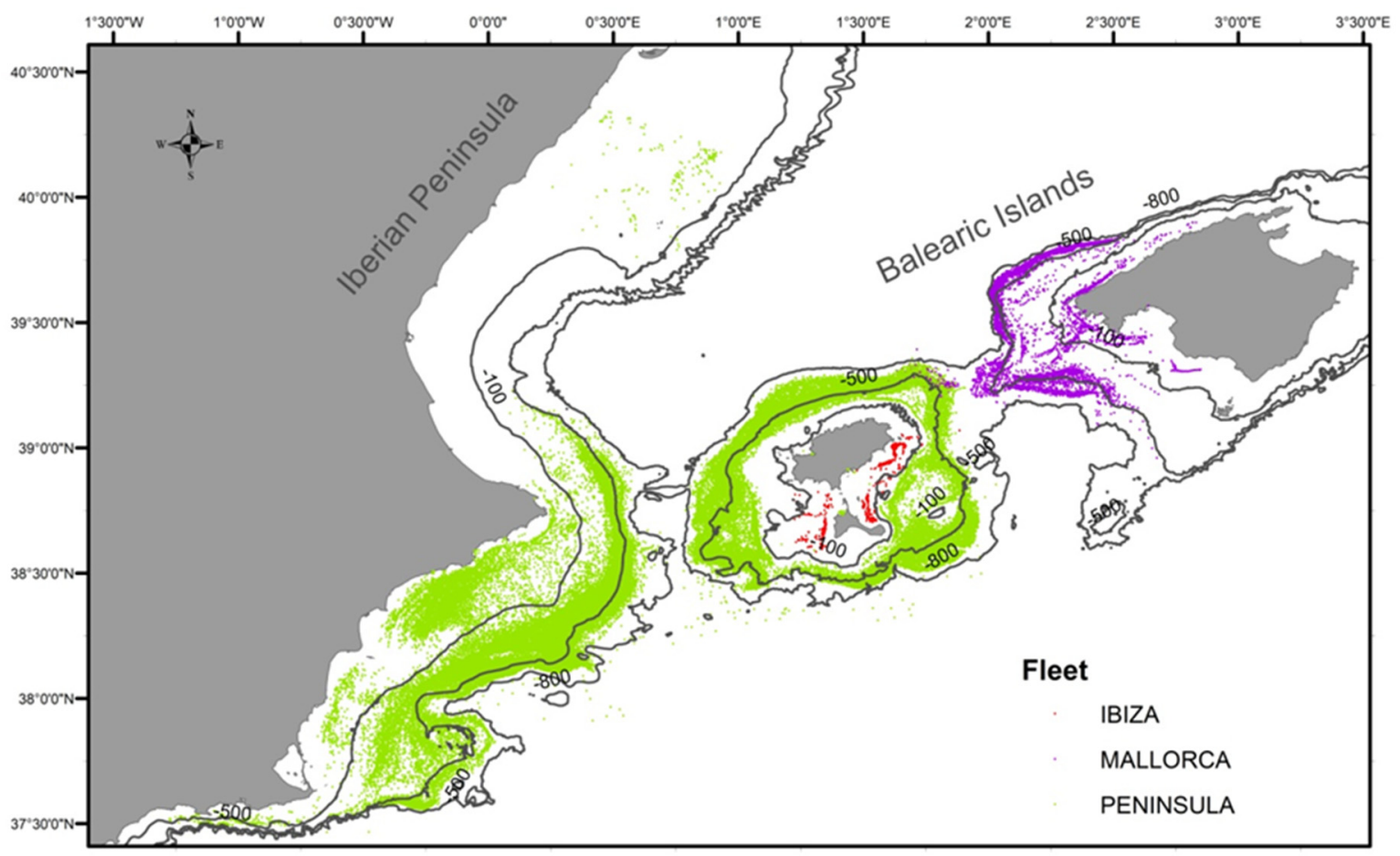

(A)

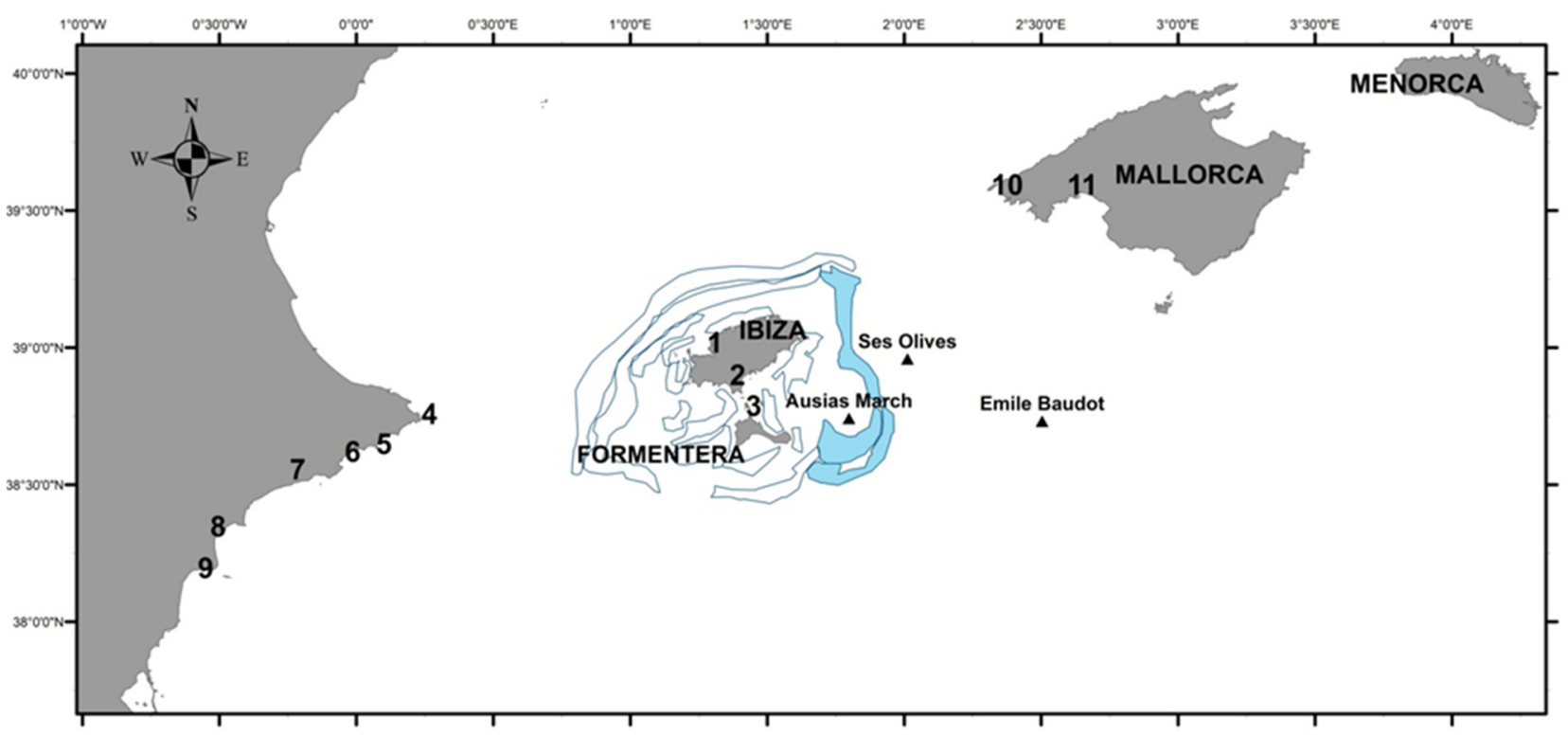

(B)

Figure 8. Bottom trawl fishing activity in the seamounts of the Mallorca Channel: (A) VMS signals during the period 2016-2019 of the fleets that operate around Ibiza and the Formentera Islands (red: vessels from ports on these islands; green: vessels from ports on the Iberian Peninsula; violet: vessels from ports on Mallorca Island), showing the three seamounts studied and the whole fishing areas of these fleets along the northwestern Mediterranean; and (B) fishing grounds located in adjacent bottoms of the Ses Olives and Ausias March seamounts, identified from the cartography of all fishing grounds around the Balearic Islands from VMS signals [60], showing the base port fleets operating in the study area: (1) Sant Antoni de Portmany; (2) Eivissa; (3) La Savina; (4) Xàvia; (5) Calp; (6) Altea; (7) La Vila Joiosa; (8) Alicante; (9) Santa Pola; (10) Andratx; and (11) Palma.

Three different fishing grounds were identified in the vicinity of $\mathrm{SO}$ and $\mathrm{AM}$ (Figure 8B): (i) one situated east and northeast of Ibiza Island, with its southern part including upper 
and middle slope bottoms adjacent to SO and AM; and (ii) two situated east of Formentera, one including upper slope bottoms and the other including middle slope bottoms, in both cases adjacent to AM. These fishing grounds correspond to slope bottoms, where the insular trawling fleets of Ibiza and Formentera do not operate. They are mainly exploited by the trawling fleet from the Iberian Peninsula targeting deep water decapod crustaceans of high economic value such as rose shrimp (P. longirostris) and Norway lobster (N. norvegicus) on the upper slope and the red shrimp on the middle slope.

On average, these three fishing grounds represent $16 \%$ of the fishing days conducted by the trawl fleet around Ibiza and Formentera. They concentrated $28 \%$ of the fishing days conducted by the Iberian Peninsula fleet around these two islands and 13\% of its fishing days with respect to the whole fishing area of this fleet including both insular and peninsular fishing grounds. The fleet from Mallorca only operates in the northernmost part of the fishing ground in eastern and northeastern Ibiza, which on average concentrates up to $45 \%$ of the fishing days developed by this fleet when operating near Ibiza and less than $6 \%$ of its fishing days with respect to its whole fishing area, mainly western and southern Mallorca.

Up to 16 species or commercial categories were identified as the most important catches of the trawling fleet operating on slope bottoms around Ibiza and the Formentera Islands (Table 4): rose shrimp, Norway lobster, red shrimp, the deep water crab G. longipes and other category of decapod crustaceans composed by species of the genus Plesionika, a category of cephalopod mollusk composed by the Ommastrephidae species Illex coindetii, Todaropsis eblanae and Todarodes sagittatus, the teleost fishes hake (M. merluccius), spotted flounder (Citharus linguatula), blackbelly rosefish (H. dactylopterus), blue whiting (Micromesistius poutassou), greater forkbeard (Phycis blennoides), monkfishes (Lophius budegassa and $L$. piscatorius), megrims (L. boscii and L. whiffiagonis), a category composed by species of the family Argentinidae (Glossanodon leioglossus and Argentina sphyraena), the elasmobranch blackmouth catshark (G. melastomus), and a category composed of species of the family Rajidae. These species or commercial categories represent $>90 \%$ of total landings in terms of biomass and $>92 \%$ in terms of economic value. 
Table 4. Estimated annual landings, in terms of biomass $(\mathrm{kg})$ and economic value ( $€$ from first sale), for the main species or commercial categories extracted from the three bottom trawl fishing grounds in adjacent bottoms of the Ses Olives and Ausias March seamounts in the Mallorca Channel (Balearic Islands, western Mediterranean), and average values ( \pm standard error) during the period 2016-2019. The location of these fishing grounds is shown in Figure 9B.

\begin{tabular}{|c|c|c|c|c|c|c|c|c|c|c|c|c|}
\hline \multirow[b]{2}{*}{$\begin{array}{l}\text { Species or } \\
\text { Category }\end{array}$} & \multicolumn{2}{|c|}{2016} & \multicolumn{2}{|c|}{2017} & \multicolumn{2}{|c|}{2018} & \multicolumn{2}{|c|}{2019} & \multicolumn{4}{|c|}{ Average Whole Period } \\
\hline & kg & $€$ & kg & $€$ & kg & $€$ & kg & $€$ & $\mu(\mathrm{kg})$ & SD (kg) & $\mu(€)$ & $\operatorname{SD}(€)$ \\
\hline Argentinidae & 318 & 849 & 4005 & 9223 & 6136 & 16,381 & 4726 & 14,224 & 3796 & 2482 & 10,169 & 6899 \\
\hline $\begin{array}{l}\text { Citharus } \\
\text { linguatula }\end{array}$ & 2 & 4 & 1881 & 5527 & 10,837 & 40,892 & 8611 & 40,829 & 5333 & 5208 & 21,813 & 22,109 \\
\hline $\begin{array}{c}\text { Galeus } \\
\text { melastomus }\end{array}$ & 98 & 368 & 96 & 492 & 875 & 2988 & 1493 & 5171 & 640 & 677 & 2255 & 2288 \\
\hline Geryon longipes & 5657 & 27,320 & 8589 & 39,188 & 7026 & 32,608 & 9713 & 27,199 & 7746 & 1776 & 31,578 & 5665 \\
\hline $\begin{array}{c}\text { Helicolenus } \\
\text { dactylopterus }\end{array}$ & 499 & 1717 & 2876 & 5131 & 9340 & 22,458 & 10,490 & 24,994 & 5801 & 4871 & 13,575 & 11,849 \\
\hline $\begin{array}{l}\text { Lepidorhombus } \\
\text { spp. }\end{array}$ & 1582 & 8009 & 1675 & 8358 & 1616 & 7345 & 2489 & 14,066 & 1840 & 434 & 9445 & 3110 \\
\hline Lophius spp. & 2453 & 23,449 & 4065 & 28,998 & 10,268 & 70,846 & 12,847 & 90,179 & 7408 & 4949 & 53,368 & 32,402 \\
\hline $\begin{array}{l}\text { Merluccius } \\
\text { merluccius }\end{array}$ & 1672 & 11,949 & 3055 & 20,633 & 8992 & 46,242 & 13,416 & 90,701 & 6784 & 5444 & 42,381 & 35,350 \\
\hline $\begin{array}{l}\text { Nephrops } \\
\text { norvegicus }\end{array}$ & 2977 & 72,615 & 5840 & 148,117 & 16,302 & 445,533 & 20,547 & 496,826 & 11,417 & 8358 & 290,773 & 211,623 \\
\hline Ommastrephidae & 323 & 525 & 3242 & 8913 & 8929 & 23,541 & 5585 & 20,363 & 4520 & 3643 & 13,335 & 10,602 \\
\hline Pandalidae & 2302 & 17,213 & 2957 & 20,352 & 4518 & 30,692 & 5784 & 43,262 & 3890 & 1568 & 27,880 & 11,761 \\
\hline $\begin{array}{l}\text { Parapenaeus } \\
\text { longirostris }\end{array}$ & 136 & 1419 & 4541 & 50,727 & 20,935 & 249,009 & 19,137 & 258,024 & 11,187 & 10,401 & 139,795 & 132,899 \\
\hline $\begin{array}{c}\text { Phycis } \\
\text { blennoides }\end{array}$ & 2005 & 4984 & 5191 & 15,486 & 11,318 & 30,043 & 13,132 & 34,524 & 7912 & 5200 & 21,259 & 13,556 \\
\hline Rajidae & 285 & 958 & 1924 & 2676 & 2996 & 8085 & 4813 & 11,485 & 2505 & 1900 & 5801 & 4856 \\
\hline TOTAL & 24,593 & 268,004 & 56,037 & 465,652 & 128,523 & $1,223,475$ & 161,309 & $1,645,048$ & 92,616 & 63,175 & 900,545 & 644,931 \\
\hline
\end{tabular}



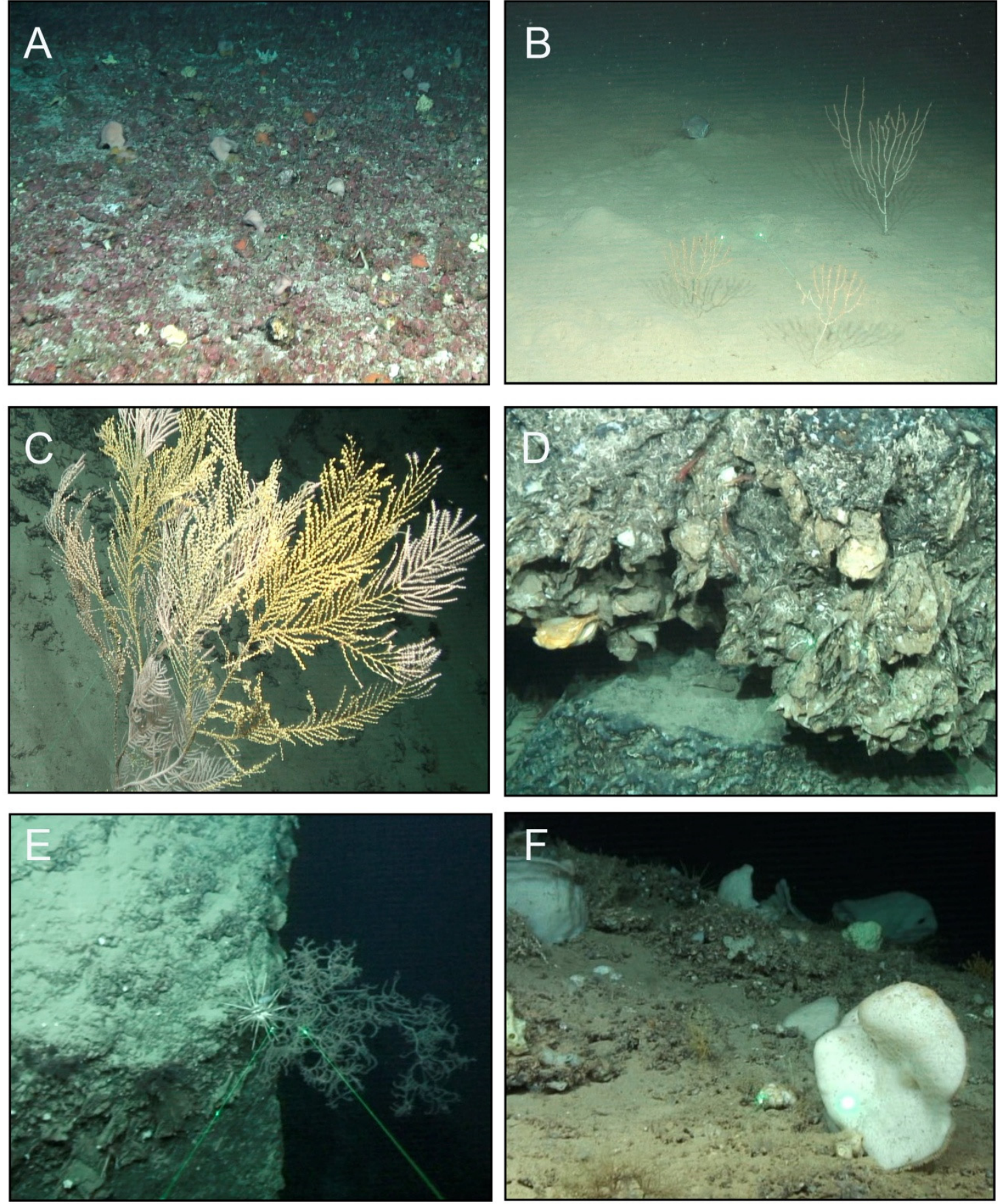

Figure 9. Habitats and biological communities identified in the Ses Olives (SO), Ausias March (AM), and Emile Baudot (EB) seamounts of the Mallorca Channel (Balearic Islands, western Mediterranean): (A) Rhodolith beds in EB at $113 \mathrm{~m}$ depth); (B) bathyal muds with Alcyonacea (Isidella elongata) in SO at a $590 \mathrm{~m}$ depth; (C) bathyal rock with Alcyonacea (Callogorgia verticillata) in EB at a $830 \mathrm{~m}$ depth; (D) upper bathyal biogenic Thanatocoenosis of giant ostreids in EB at a $417 \mathrm{~m}$ depth; (E) bathyal rock with Anthipataria (Leiopathes glaberrima) in EB at a $491 \mathrm{~m}$ depth; and (F) bathyal rocky bottoms with coarse sediments dominated by sponges in AM at a $365 \mathrm{~m}$ depth.

On average, the annual catches of these species or commercial categories obtained by the trawling fleet from the three fishing grounds adjacent to the SO and AM seamounts represent $24 \%$ of their landings from all trawl fishing grounds around Ibiza and Formentera and $25 \%$ in terms of their economic value (Table 4 ). These landings represent $35 \%$ of the annual biomass of these species extracted by the fleet from the Iberian Peninsula on the 
fishing grounds around Ibiza and Formentera, and 7\% from their landings obtained both on insular and peninsular fishing grounds. In terms of economic value, these figures were 32 and 7\%, respectively (Table 4). Regarding the vessels from Mallorca Island, their landing obtained in the northernmost part of the fishing ground in eastern and northeastern Ibiza represent up to $83 \%$ of the annual biomass extracted by these vessels from the fishing grounds in this area and $84 \%$ of its economic value, but they only represented 2 and $1.5 \%$ of their total landings in terms of biomass and economic value, respectively (Table 4).

\subsection{Habitats}

Up to 29 different categories of benthic habitats were identified from ROTV and ROV video transects (Table 5; Figure 9). Two of them are considered protected habitats: rhodoliths beds and coralligenous bottoms. Five of them were designated as sensitive habitats: (i) bathyal muds with Isidella elongata; (ii) facies with crinoids, (iii) facies with red algae of the genus Peyssonnelia; (iv) rhodoliths beds; and (v) communities of bathyal detritic sands with Gryphus vitreus.

The analysis of video transects obtained with ROTV (Figure 10) showed that dominant habitats in $\mathrm{SO}$ were soft bottoms. Bathyal mud with burrowing mega-fauna dominated around the seamount and detritic bottoms on the summit, both habitats summing up $87.5 \%$ coverage. On the flanks, hard bottoms with bathyal rock, dominated by sponges were found, with $11.5 \%$ coverage. In the summit of AM there were rhodolith beds (16\%), alternating with detritic bottoms $(30 \%)$, while in the base, soft bottom with pockmarks $(13 \%)$ and bathyal detritic bottoms (30\%) predominated. On flanks, escarpments, rocky walls, and slopes with anthozoans and/or small sponges such as Thenea muricata were also found. Rhodolith beds with invertebrates, especially anthozoans (alcyonarians and gorgonians) and sponges, predominated on the EB summit (67\% coverage), while muddy bottoms were found at the base and adjacent areas.

The analysis of the ROV (Figure 10) found that the SO seafloor consisted mostly of bathyal muds ( $69 \%$ of covered area), in some areas with burrowing megafauna, and to a lesser extent, detritic bathyal bottoms and rocky slopes covered by sponges (10 and $7 \%$ coverage, respectively). Pockmarks, soft bottoms with G. vitreus or T. muricata, and rocky areas dominated by the crinoid Leptometra celtica were also found. The circa-littoral seafloor of AM was defined by rhodolith beds (33\%) and detritic sand ( $7 \%)$, dominated by alcyonids and sponges, while its bathyal areas were widely covered by sand or muddy sediments $(41 \%)$, some of them dominated by the brachiopod G. vitreus (3\%). The rocky slopes and escarps of AM were covered mainly by sponges (10\%), but also by the cnidarians Paramuricea hirsuta (1.6\%) and Bebryce mollys (1\%). EB, with the widest depth range of visual deployments, showed a circa-littoral domain with detritic soft bottoms (38\%), some dominated by the soft red algae Phyllophora crispa, the alcyonids Alcyonium palmatum and Paralcyonium spinulosum, and rhodolith beds. The bathyal transects showed mainly muddy or soft detritic sediments ( $22 \%$ and $38 \%$, respectively), with dead coral mounds and pockmarks. The hard substrates were dominated by sponges, the crinoid L. celtica, and black corals.

The geographic distribution of the habitats (Figure 10) showed that the lowest number of habitats was observed in SO (11) and the highest in EB (21). AM presented an intermediate number of habitats (16), despite being the seamount with less video transect sampling. In general, thanatocoenosis of giant ostreids seemed to be distributed around the three seamounts and dead coral framework, and mounds were also found in some bathyal areas of their flanks. 
Table 5. Categories of benthic habitats identified from ROTV and ROV video transects in th Ses Olives, Ausias March, and Emile Baudot seamounts of the Mallorca Channel (Balearic Islands, western Mediterranean) during the INTEMARES project. Their name, code, and hierarchical organization level (HOL; ranging from 1 for the more generalist and least detailed one to 5 for the level with the highest detail and knowledge) were assigned according to the Habitats Directive, with some exceptions $\left(^{*}\right)$ identified during the previous INDEMARES project (https:/ / www.indemares.es/en (accessed on 15 December 2021)).

\begin{tabular}{|c|c|c|c|}
\hline Habitat Name & Code & HOL & Habitat Assignment \\
\hline \multirow{10}{*}{$\begin{array}{c}\text { Sandbanks which are slightly } \\
\text { covered by sea water all } \\
\text { the time }\end{array}$} & \multirow{10}{*}{1110} & & Rhodoliths beds * \\
\hline & & & $\begin{array}{l}\text { Infralittoral and circalittoral detritic beds with rhodoliths } \\
\text { dominated by invertebrates * }\end{array}$ \\
\hline & & & $\begin{array}{l}\text { Circalittoral detritic beds with Alcyonium palmatum and } \\
\text { Paralcyonium spinulosum * }\end{array}$ \\
\hline & & 5 & $\begin{array}{l}\text { Infralittoral and circalittoral detritic beds with rhodoliths } \\
\text { dominated by invertebrates with sponges dominance* }\end{array}$ \\
\hline & & 2 & Circalittoral detritic bottoms \\
\hline & & & Circalittoral and infralittoral detritic biogenic habitats * \\
\hline & & & $\begin{array}{l}\text { Circalittoral and infralittoral detritic biogenic habitats with } \\
\text { Phyllophora crispa * }\end{array}$ \\
\hline & & 3 & Bathyal detritic bottoms \\
\hline & & & $\begin{array}{l}\text { Bathyal shelf-edge sedimentary bottoms with Brachiopoda } \\
\text { (Gryphus vitreus)* }\end{array}$ \\
\hline & & & $\begin{array}{l}\text { Bathyal mud and sandy mud bottoms dominated by } \\
\text { burrowing megafauna * }\end{array}$ \\
\hline \multirow{17}{*}{ Reefs } & \multirow{17}{*}{1170} & & Bathyal rock with Scleractinia * \\
\hline & & 5 & Bathyal rock with Alctyonacea (Paramuricea hirsuta) \\
\hline & & 4 & Dead coral framework \\
\hline & & 5 & Dead coral mounds \\
\hline & & 4 & Bathyal rock with Anthipataria (Leiopathes glaberrima) \\
\hline & & 4 & Bathyal rock with Alcyonacea (Callogorgia verticillata) \\
\hline & & 4 & Bathyal rock with coarse sediments with Bebryce mollis \\
\hline & & 4 & Bathyal rock with coarse sediments with Leptometra celtica \\
\hline & & 3 & Coralligenous rock dominated by invertebrates \\
\hline & & 3 & Circalittoral rock invertebrate-dominated \\
\hline & & 3 & Bathyal rocky bottoms with sponges aggregations \\
\hline & & 4 & Bathyal rock with coarse sediments dominated by sponges \\
\hline & & 5 & Upper bathyal biogenic Thanatocoenosis of giant ostreids \\
\hline & & 2 & Bathyal muds \\
\hline & & & Bathyal muds with small sponges (Thenea muricata)* \\
\hline & & 4 & Bathyal compact muds with Alcyonacea (Isidella elongata) \\
\hline & & & $\begin{array}{l}\text { Escarpments, rocky walls and slopes of seamounts with } \\
\text { anthozoans (scleractinians, gorgonians, and antipatharians) }\end{array}$ \\
\hline $\begin{array}{l}\text { Submarine structures made by } \\
\text { leaking gases }\end{array}$ & 1180 & 3 & Pockmarks \\
\hline
\end{tabular}



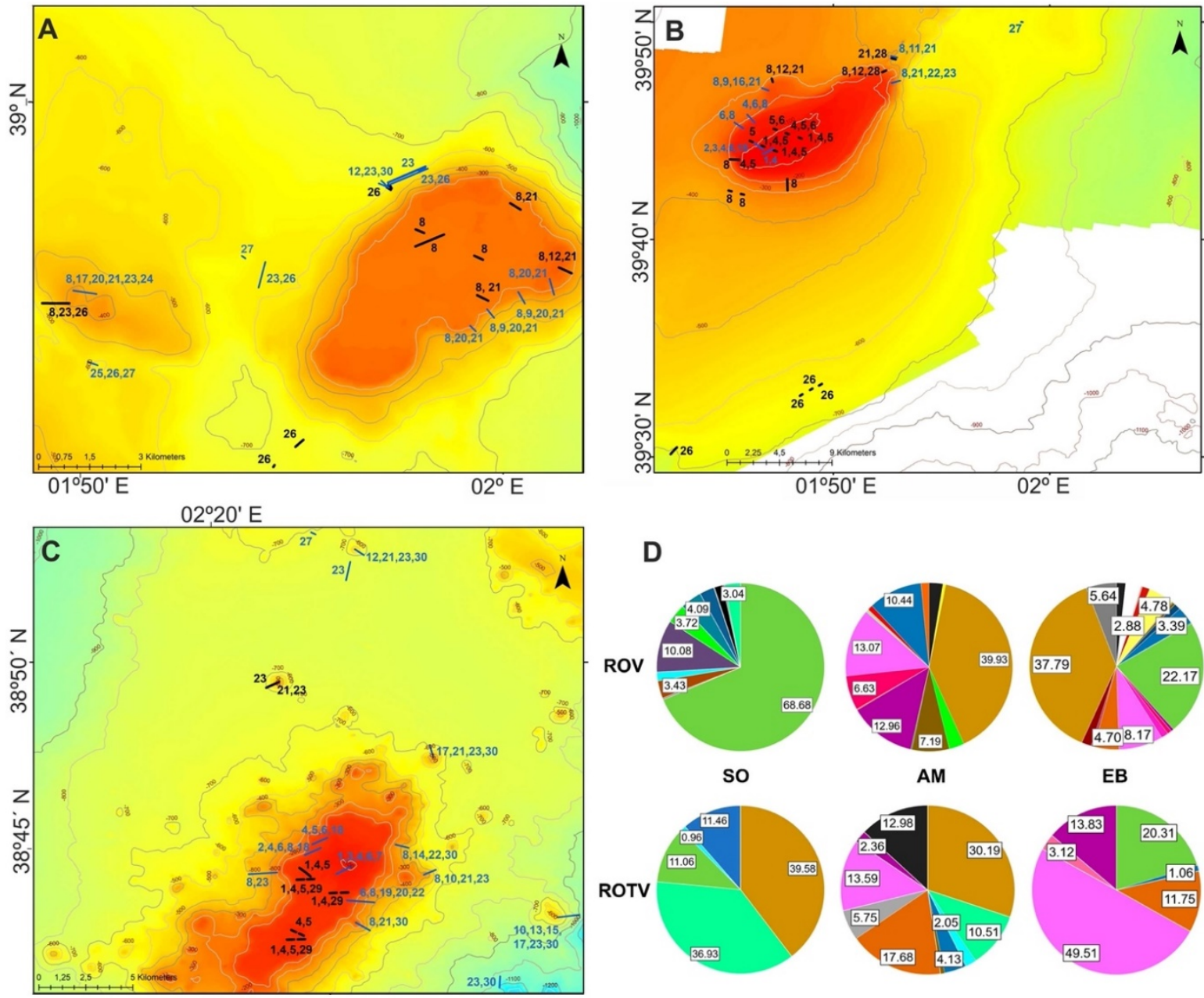

D
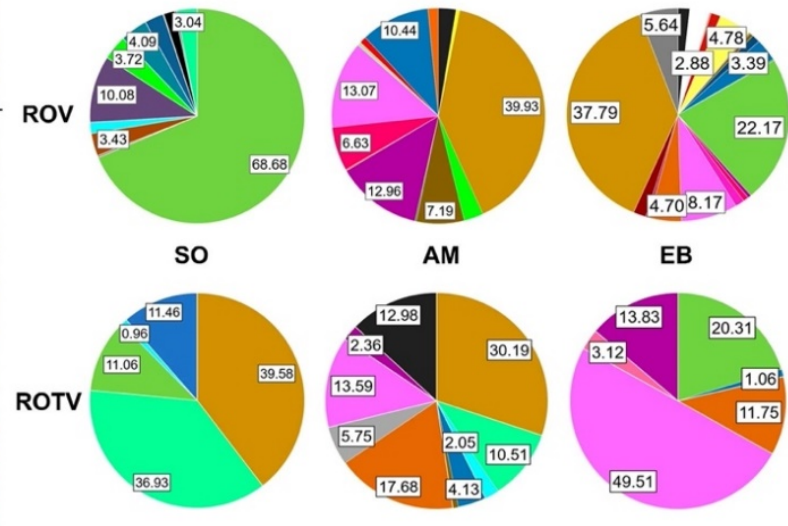

\section{Maërl/Rhodoliths beds*}

Infra- and circalittoral detritic beds with rhodoliths dominated by invertebrates * Circalittoral rhodolits beds with Alcyonium palmatum and Paralcyonium spinulosum *

Infra- and circalittoral detritic beds with rhodoliths dominated by invertebrates with sponges*

5 Circalittoral detritic bottoms

Circa- and infralittoral biogenic habitats *

Circa- and infralittoral biogenic habitats with Phyllophora crispa *

Bathyal detritic bottoms

Bathyal shelf-edge sedimentary bottoms with Brachiopoda (Gryphus vitreus)*

10 Bathyal rock with Scleractinia

11 Bathyal rock with Alcyonacea (Paramuricea hirsuta)

12 Dead coral framework

13 Dead coral mounds

14 Bathyal rock with Anthipataria (Leiopathes glaberrima)

15 Bathyal rock with Alcyonacea (Callogorgia verticillata)

\begin{tabular}{|l|l|}
\hline 16 & Bathyal rock with coarse sediments with Bebryce mollis \\
\hline 17 & Bathyal rock with coarse sediments with Leptometra celtica \\
\hline 18 & Coralligenous rock dominated by invertebrates \\
\hline 19 & Circalittoral rock Invertebrate-dominated \\
\hline 20 & Bathyal rocky bottoms with sponges aggregations \\
\hline 21 & Bathyal rock with coarse sediments dominated by sponges \\
\hline 22 & Upper bathyal biogenic Thanatocoenosis of giant ostreids \\
\hline 23 & Bathyal muds \\
\hline 24 & Bathyal muds with small sponges (Thenea muricata)* \\
\hline 25 & Bathyal compact muds with Alcyonacea (Isidella elongata) \\
\hline 26 & Bathyal mud and sandy bottoms with burrowing megafauna* \\
\hline 27 & \begin{tabular}{l} 
Pockmarks \\
\hline 28
\end{tabular} \\
\hline 29 & $\begin{array}{l}\text { Scarpments, rocky walls and slopes of seamounts with } \\
\text { anthozoans (scleractinians, gorgonians, antipatharians) } \\
\text { by alcyonarians, gorgonians and antipatharians }\end{array}$ \\
\hline 30 & No structurant species \\
\hline
\end{tabular}

Figure 10. Video transects with ROTV and ROV developed in the (A) Ses Olives; (B) Ausias March, and (C) Emile Baudot seamounts, showing the code (1-29) of the categories of benthic habitats identified. Pie charts with the coverage percentage of the main habitats by seamount are also shown (D). $\left(^{*}\right)$ Full name, code, and level of habitats are detailed in Table 5.

\section{Discussion}

The present paper includes a preview of the results obtained during the INTEMARES project regarding the mapping and characterization of seafloor, benthic species, and habitats as well as fishing activity on the SO, AM, and EB seamounts and adjacent bottoms. This multidisciplinary approach has greatly improved the scientific knowledge on the 
geological, biological, and habitat diversity of these seamounts in the Mallorca Channel, which constitutes the first step for their inclusion in the Natura 2000 network. It provides new baseline information on the diversity patterns in the area and useful details of the seascape distribution, which can be used for future ecological assessments.

\subsection{Geodiversity}

The new geomorphological mapping has enhanced between six and 20 times the bathymetric detail of the seabed. From this improvement, we differentiated, among the seamounts, 15 different morphological types: minor highs, ridges, tectonic depressions, fault scarps, pockmarks, volcanic cones, gullies, slide scars and mass-transport deposits, contourite moats, furrows and drifts, sediment waves, and numerous biogenic mounds. This great geomorphological variety of features shows the importance of the interplay of several geological (structural and fluid flow processes), oceanographic (bottom current related processes), and biogenic (bioaccumulation of reef-building organisms) processes in shaping the seafloor and influencing substrate types and benthic habitats of the Mallorca Channel.

The presence of biogenic mounds and mass-movement related features is widespread at the summits and flanks of all the seamounts and adjacent bottoms, with AM the most affected seamount by both processes. Biogenic mounds and patch settlements strongly depend on the availability of hard substrates [61] such as the rocky outcrops identified at these summits, occurring in at least half of the summit surface of AM and EB, but being less represented at the summit and upper flanks of SO. They were previously reported by OCEANA $(2011,2015)[13,14]$, although their distribution was more than double that described, probably due to the widest depth range analyzed in the present study. All seamounts have flat-topped summits and some develop terraced levels, suggesting that they were once islands that later on became submerged edifices associated with different mechanisms such as wave erosion at the sea surface, water mass interaction, or affected by subsidence $[62,63]$. These processes, together with other environmental conditions such as the hydrodynamic regime and the sufficient productivity, have modulated the morphology of these structures.

The seafloor surface affected by sedimentary instabilities is $12 \%$ of the study area $\left(\sim 600 \mathrm{~km}^{2}\right)$, a value double that of that previously estimated for the Balearic Promontory by Acosta (2005) [64]. At the same time, they are related to zones of fragility associated with structural and fluid flow processes such as active faulting, folding, and pockmark development, as has been suggested by Iglesias et al. (2010) and Palomino et al. (2011) [4,65] in the Cantabrian and Alboran seas, respectively.

Pockmarks have been categorized as habitat type 1180 "Submarine structures made by leaking gases" in the Habitats Directive 92/43/EEC, which has a restricted distribution in European waters, with the Mediterranean one of these areas where this habitat is located. However, it remains unrepresented within the Mediterranean Natura 2000 network [18]. Previous studies have identified some pockmarks in the Mallorca and Ibiza Channel and Iberian Peninsula area [66], with our results in line with these findings. However, we highlighted the presence of almost 4000 pockmarks that largely developed surrounding the three seamounts with deep bottoms up to $1000 \mathrm{~m}$ in depth. These pockmarks occur in areas with great sedimentary thickness, where the higher sedimentation rates favor the burial of organic matter and make it more prone to anaerobic digestion. In this sense, the location of the large pockmark fields displays the highest organic matter values in superficial sediments of the study area.

The formation of pockmarks has been univocally proposed in the literature as caused by the existence of fluid escape processes, water or gas, preferably gas such as methane from the subsoil [67] whose expulsion would favor the erosion of sediments. These seafloor depressions can also be affected by bottom currents, which may favor their erosion and genesis. In the Mallorca Channel, these fluid flow features can be found in different evolutionary phases, although in some cases, the occurrence of underneath acoustic chimneys 
in the subsoil has been located in the high resolution parametric profiles. The origin of these acoustic masking features has been proposed in the literature as amplitude anomalies related to free gas that is migrating upward through the sediments toward the seabed (e.g., [68]).

Another feature to remark on is the volcanic cone field (up to 170 edifices) restricted to the flanks and adjacent bottoms of EB, a seamount that unlike SO and AM is of volcanic origin [11]. The presence of numerous volcanic cones suggests a multiple focused extrusion paths towards the seafloor. High-resolution sub-bottom profiles show low penetration on them, indicating the absence of a recent unconsolidated sedimentary cover, that point out to the availability of hard substrates at these structures for reef-forming organisms, as reported for the seamounts. Furthermore, volcanic cones and pockmarks are spatially interspersed along the periphery of EB, fact that could influence the fluid flow process development onto the seafloor.

\subsection{Biodiversity, Communities, and Habitats}

The flora and fauna inventoried, with up to 547 species or taxa, have also contributed to improve the knowledge of the biodiversity of the study area. In contrast to previous studies, developed exclusively from visual censuses and samples of benthic organisms using ROV $[13,14,17]$, the combination of sampling methods used in the present study (epi-benthic sledge, bottom trawl, rock dredge, and ROV) has allowed us to cover not only a wide range of species including small-sized benthic organisms, species difficult to identify only from images and highly mobile nekton-benthic fishes, but also to achieve a more precise identification of them by obtaining more samples to be analyzed in the laboratory.

Some of the identified species up to date have been new to science and new records in the study area or even in the Mediterranean. This is the case of the discovery of the new genus of sponge Foraminospongia, whose type species F. balearica is one of the most abundant sponges at the AM and EB summits and the other two new sponge species F. minuta and Paratimea masuttii [69]. Moreover, new geographical records have been published for another 16 sponges [69] and one ophiuroid [70], with this last species also abundant in the study area. Some species have been found at depths where they had not been previously recorded, which was the case of two little known decapod crustaceans: the alpheids Alpheus platydactylus and Alpheus cf. dentipes. Up until now, the first species had been reported at depths of 120-791 m [71-73], but we collected a male and an ovigerous female at $88 \mathrm{~m}$ depth in the coralligenous bottoms of EB. The second was collected at a $305 \mathrm{~m}$ depth in SO, but this species had always been reported at shallow infra-littoral bottoms inside sponges, rock cavities, and among calcareous algae [71,74-77]. Although the species was identified as A. cf. dentipes according to Noël (1992) [78], these differences in bathymetry cause doubt about its specific assignment, pending future studies. The report of the sepiolid Stoloteuthis leucoptera in the fishing grounds adjacent to AM must also be pointed out. This species is a deep-sea cephalopod, whose presence in the Mediterranean is very rarely known [79].

These invertebrate groups are good examples of the limitations regarding the identification of species only from images. Since Pitcher et al. (2007) [80], the assessment of benthic species richness on seamounts can be strongly influenced by the sampling methodology applied, with extractive sampling yielding broader estimation of biodiversity. Moreover, with these sampling methods, it is possible to obtain individuals and perform the detailed morphological and genetic analyses needed for the description and identification of new species or records [81]. This is clear from the number of species inventoried exclusively using one or another sampling method. From the 537 species or taxa detected in the Mallorca Channel seamounts, only 110 have been detected using both images and one of the three sampling gears. The majority of these species have been exclusively detected using gears, up to 484 , whereas only 54 of them were exclusively detected from the images. The most effective sampling gear was the beam trawl, with up to 184 species detected exclusively 
using this gear, whereas 51 and 41 species were exclusively detected using bottom trawl and rock dredge, respectively.

However, ROV images are very useful for sampling rocky bottoms and to improve the information collected with epi-benthic sledge and bottom trawling on sedimentary bottoms. In rocky bottoms, images and samples from ROV can allow for the estimation of the standardized density of benthic flora and fauna and to detect highly mobile nektonbenthic species. This was the case of Trachyscorpia cristulata echinata and Pontinus kuhlii, observed in EB from our study and OCEANA (2011) [13], respectively. Both scorpionfishes are poorly known in the Mediterranean, probably because their preferential habitat is not accessible to the more conventional and widespread sampling in the area for nektobenthic species, developed from bottom trawl gears. In fact, these findings represent the second report of both species in the Balearic Islands [82,83]. In the case of sedimentary bottoms, ROV or photogrammetric sledge images can provide information on the spatial distribution of benthic species (e.g., patchiness) and the tridimensional structure of habitats, thus providing a more realistic picture. All these results emphasize the importance of combining complementary sampling methods to assess the diversity of seamounts.

In most seamount studies, depth has been shown to be the most important environmental factor in determining the structure of benthic assemblages, which generates their distribution as bands encircling the seamounts [84,85]. Our results are not an exception, and the assemblages of benthic and nekton-benthic species identified both in sedimentary and rocky bottoms of the Mallorca Channel follow a clear bathymetric distribution, with different communities in the summit, flanks and base that is also related to the substrate type. Albeit to a lesser degree, we have also detected differences in epi-benthic species composition between the seamounts, both at summits, characterized by coarser sediment, high content in inorganic carbon, and low content in organic matter as well as in flanks and bases, mainly dominated by finer sediments, low content in organic carbon, and high content in organic matter. These differences were lower for the nekton-benthic assemblages in the trawl fishing grounds adjacent to AM and EB. This result should be highlighted considering the different level of exploitation of the fishing grounds compared. While AM has been exploited by the bottom trawl fleet targeted to red shrimp (A. antennatus) for more than 50 years [86], this fishery has not been developed in EB during the last two decades because of its large distance from any port, and more recently, the high fuel cost [44]. Despite this, the only difference that could be attributable to the impact of fishing is the slightly greater abundance of the elasmobranch G. melastomus observed in EB compared to AM (on average, 21.0 vs. 17.2 individuals $/ \mathrm{km}^{2}$, respectively), although the other elasmobranch Etmopterus spinax showed a contrary situation (on average, 6.2 vs. 1.2 individuals $/ \mathrm{km}^{2}$, respectively). In contrast, red shrimp did not show differences in its abundance, only in its length frequency.

The gradient of habitats found also followed the depth range. In the circalittoral summits of AM and EB, there are detritic bottoms with rhodolith beds and coralligenous outcrops, dominated by communities of sponges and alcyonarians and gorgonian anthozoans. As a consequence of the extreme transparency of the water in these areas, these rhodolith beds have been found quite well structured down to a $137 \mathrm{~m}$ depth, most likely the deepest depth of this habitat in the western Mediterranean. As above-mentioned, most of SO summit is flat and is covered by detritic bottoms, which is in contrast to the seafloor around this seamount, containing mud and sandy mud beds dominated by burrowing fauna, as occur in the Gulf of Cadiz [87]. Sponges and corals colonize the rocky bottoms of the flanks, in the upper slope of the three seamounts. These filtering species seem to be more frequent and abundant in the flanks facing the main current directions, probably as a consequence of a current-mediated increase in food availability, an aspect that should be further investigated in studies of habitat and species modeling. Other habitats in this bathymetric range were some crinoid beds and thanatocoenosis of giant ostreids, which seems to surround each seamount between 260 and $415 \mathrm{~m}$ in depth. In the less steep flaks and bathyal terraces of the upper and middle slope were muddy soft sediments 
accumulating facies of the brachiopod G. vitreus, burrowing megafauna and/or dead coral debris. The deepest areas of the middle slope at the base of seamounts are dominated by the finest muddy sediments and the presence of pockmarks. In these bottoms, facies with the corals Callogorgia verticillata and Isidella elongata, the sponge Thenea muricata, and the bryozoan Kinetoskias sp. have also been found.

\subsection{Fisheries}

Currently, deep water bottom trawl fishing activity is developed on adjacent bottoms of SO and AM. The comparison of the epi-benthic and nekton-benthic assemblages and one of the main fishing resources (red shrimp) between these fishing grounds and a fishing ground adjacent to EB that has not been exploited by the trawling fleet for 20 years did not show clear differences. However, these results must be considered as very preliminary and further studies to assess the impact of fishing activities on species and habitats will be necessary.

These studies should also consider the direct impact of trawling gears on the seafloor, because bottom trawling has also been reported as an important driver of sediment resuspension, caused by the passage of the fishing gear through bottoms, becoming an important seafloor micro-morphology disturbing process in muddy and moderate-energy continental shelves [88] and a driver of deep seascape evolution [89,90]. Sediment resuspended, as a result of trawl fishing, also has a wide variety of additional effects including the smothering of feeding and respiratory organs [91], which can affect the settlement and feeding of the biota. Hence, the potential effect of these sediments reaching and settling in the seamounts should be assessed, considering the high diversity and density of filtering benthic species inhabiting both the sedimentary and rocky bottoms of the SO and AM seamounts and adjacent areas.

The potential impact of other demersal fishing gears should also be considered in these studies. This was the case for two commercial fleets operating with traps and bottom long-lines on the summits and flanks of the three seamounts and the recreational fleet operating with hand-lines. The activity and catches of this last fishery is largely unknown. Although traps and long-lines are more selective than bottom trawl and their impact is much less, it can still be significant not only on their target species, but also on benthic habitats [92]. Moreover, it must be taken into account that these fishing gears operate in areas not accessible to trawling.

\subsection{Ecological Value of Mallorca Channel Seamounts}

Most of these habitats are included in the Habitats Directive (HD) as being of community interest (habitat codes 1110,1170, and 1180) and are of high ecological value, not only because of the high species diversity they house, some of which are threatened or declining, but also because some of them are considered as sensitive or vulnerable habitats and, for that reason, they have been protected by both environmental and fisheries regulations. That is the case of maërl or rhodoliths and coralligenous beds, which the Council Regulation No. $1967 / 2006$, concerning management measures for the sustainable exploitation of fishery resources in the Mediterranean Sea, considers as protected habitats and prohibits fishing with bottom trawls on these bottoms. To implement this, in 2014, the Spanish Ministry for Agriculture, Fisheries, and Food declared the summits of AM and EB as fishing protection zones in which trawling was forbidden. Until then, the AM summit had hosted some trawl fishing grounds, which are currently not exploited. Maërl/rhodolith beds have also been considered as Essential Fish Habitats because they are necessary for the development of critical life stages of exploited fish species, and require special protection to improve stock status and the long-term sustainability of fisheries [93].

Some of the inventoried species are considered of conservation interest, according to Annex IV of the HD (species that need strict protection), Annex II of the Barcelona Convention (endangered or threatened species), and the Spanish List of Wild Species under Special Protection Regime (Law 42/2007 on Natural Heritage and Biodiversity), which include 
species, subspecies, and populations deserving of attention and particular protection based on the scientific, ecological, and/or cultural value due to its uniqueness, rarity, or degree of threat as well as species that appear as protected in directives and international conventions ratified by Spain, and the Balearic Catalog of Threatened and Special Protection Species (Decree 75/2005). This is the case of the Corallinaceae red algae Lithothamnium coralloides and Phymatholithon calcareum, the sponges Axinella polypoides and Tethya sp., the gastropod mollusk Ranella olearium, and the corals Callogorgia verticillata, Dendrophyllia cornigera, and Madrepora oculata. Other anthozoans such as the bamboo coral I. elongata, the sea pen Funiculina quadrangularis, and the whip coral Viminella flagellum, not included in the previous regulations but catalogued by the International Union for the Conservation of Nature (IUCN) as Critical Endangered, Vulnerable and Near Threatened, respectively [94] have also been observed. In addition, the elasmobranch Centrophorus uyato, catalogued by IUCN as Endangered [95], has also been recorded. To these benthic and nekton-benthic species must be added especially protected pelagic species that have also been reported in the seamounts of the Mallorca Channel. This is the case of the sea turtle Caretta and the cetaceans Delphinus delphis, Stenella coeruleoalba, Tursiops truncates, and Physeter macrocephalus [13]. Recent studies have also suggested that these seamounts and the area around them are an important enclave for this last species and have reported the presence of two other cetaceans: Grampus griseus and Globicephala melaena (Unpublished data, Fundación TURSIOPS).

The high heterogeneity of habitats found is in concordance with previous studies in the area [13,14] and encompasses similar values in the nearby Menorca Channel [59,96-99] and other Mediterranean seamounts $[100,101]$. However, the number of habitats identified in the Mallorca Channel seamounts is higher than that of the Seco de los Olivos seamount [101,102], one of the closest and recently studied seamounts in the western Mediterranean. This could be due to the widest depth range analyzed, the special oceanographic characteristics of the SO, AM, and EB seamounts in between the Balearic and Algerian sub-basins [20], and the large heterogeneity of environments, both hydrographic and geo-morphological, as has been found in other seamounts $[84,85,103]$. Other explanatory factors may include biotic (e.g., availability of food or space for attachment and competition) and abiotic characteristics, taking into account the different origin of SO and AM, made up of carbonate materials like most of geological units of the Balearic Promontory, with respect to EB of volcanic origin, which increase the availability of different substrate types, promoting a wide variety of habitats.

Our results agree with Galil and Zibrowius (1998) [104] who suggested that Mediterranean seamounts can be considered as isolated refuges for relict populations of species that have disappeared from a previously larger distribution range [70] and that also provide an excellent habitat for rich communities of filter-feeding animals such as sponges [69]. This fact, together with the presence of species and habitats of special interest for their protection, justify the inclusion of the seamounts of the Mallorca Channel within the Natura 2000 network. This will complement the marine SCIs of the Balearic Islands because all of them are sited in coastal areas, with the only exception of the Menorca Channel, which also includes circa-littoral and bathyal bottoms $[96,105]$. This will also expand the SCIs that include seamounts in Mediterranean waters off Spain, until now represented only by the Seco de los Olivos in the Alboran Sea [101,102] and the deep-sea habitats corresponding to 1170 and 1180 types, which are not well-represented in the Mediterranean Natura 2000 network [18].

To do this, benthic species and habitat modeling as well as mapping of fishing and other human activities in the area (e.g., shipping) that can also affect sea turtles and cetaceans should be made. These studies, together with the assessment of their impact in terms of species and habitat degradation and loss of diversity, both geological and biological, will provide the required scientific information to propose the seamounts of the Mallorca Channel as a SCI and to provide advice to develop the management plan required 
for its final declaration as a SAC, with the objective to maintain not only their biodiversity and ecosystems, but also the services they provide.

Author Contributions: Conceptualization, E.M.; Funding acquisition, E.M.; Methodology, E.M., O.S.G., M.T.F., D.P., P.B., B.R., N.M.-C., S.K., C.L.-R., N.L.-G., E.M.-H., U.F.-A., F.F., F.O. and J.-T.V.; Species identification, M.T.F., S.J. and F.O. (algae), J.A.D. (sponges), E.M.-H., M.V. and S.R.-A. (crustaceans and mollusks), F.O. (echinoderms and fishes), M.T.F. and F.O. (ascidians), S.R.-A. (elasmobranchs), M.T.F., B.R., E.M.-H., U.F.-A., M.V., S.R.-A. and F.O. (other taxa); Formal analysis, O.S.-G., M.T.F., B.R., S.K., C.L.-R., N.L.-G., E.M.-H. and U.F.-A.; Data curation, All authors; Writing-original draft, E.M. and O.S.-G.; Writing-review \& editing, All authors; Supervision, E.M., A.F. and J.-T.V. All authors have read and agreed to the published version of the manuscript.

Funding: This research was performed in the scope of the LIFE IP INTEMARES project, coordinated by the Biodiversity Foundation of the Ministry for the Ecological Transition and the Demographic Challenge. It receives financial support from the European Union's LIFE program (LIFE15 IPE ES 012). The MEDITS surveys are co-funded by the European Union through the European Maritime and Fisheries Fund (EMFF) within the National Program of collection, management, and use of data in the fisheries sector and support for scientific advice regarding the Common Fisheries Policy. J.A. Díaz and S. Ramírez-Amaro are supported by predoctoral and postdoctoral contracts, co-funded by the Regional Government of the Balearic Islands and the European Social Fund.

Institutional Review Board Statement: Not applicable.

Informed Consent Statement: Not applicable.

Data Availability Statement: Data are stored in the database of the Instituto Español de Oceanografía (IEO) for the INTEMARES project, some of which is available at the IEO marine geospatial information viewers and services: http:/ / www.ieo.es/en/ideo (accessed on 15 December 2021).

Acknowledgments: We thank all participants who took part in the surveys INTEMARES_A22B_0718, INTEMARES_A22B_1019, INTEMARES_A22B_0720, INTEMARES_A22B_0820,MEDITS_ES_GSA5_2020, MEDITS_ES_GSA5_2021, and MEDITS-PITIÜSES-2021, as well as the captains and crew of the R/Vs Ángeles Alvariño, Sarmiento de Gamboa and Miguel Oliver.

Conflicts of Interest: The authors declare no conflict of interest.

\section{Appendix A}

Table A1. Characteristics of the sampling stations carried out with Shipek (SK) and Box-Corer (BC) dredges in the Mallorca Channel seamounts Ses Olives (SO), Ausias March (AM), and Emile Baudot (EB) as well as those of the central basin (CB) and the main pockmark fields (PK) during the INTEMARES project.

\begin{tabular}{cccccc}
\hline Code & Dredge & Area & Latitude (N) & Longitude (E) & Depth (m) \\
\hline A22B_0718_SK025 & SK & AM & $38^{\circ} 44.32^{\prime}$ & $001^{\circ} 46.05^{\prime}$ & 110 \\
\hline A22B_0718_SK026 & SK & AM & $38^{\circ} 43.95^{\prime}$ & $001^{\circ} 46.58^{\prime}$ & 88 \\
\hline A22B_0718_SK027 & SK & AM & $38^{\circ} 43.87^{\prime}$ & $001^{\circ} 46.58^{\prime}$ & 86 \\
\hline A22B_0718_SK028 & SK & AM & $38^{\circ} 43.47^{\prime}$ & $001^{\circ} 46.85^{\prime}$ & 98 \\
\hline A22B_0718_SK029 & SK & AM & $38^{\circ} 43.37^{\prime}$ & $001^{\circ} 46.70^{\prime}$ & 99 \\
\hline A22B_0718_SK031 & SK & AM & $38^{\circ} 45.42^{\prime}$ & $001^{\circ} 46.34^{\prime}$ & 125 \\
\hline A22B_0718_SK033 & SK & AM & $38^{\circ} 46.96^{\prime}$ & $001^{\circ} 45.44^{\prime}$ & 324 \\
\hline A22B_0718_SK034 & SK & AM & $38^{\circ} 45.16^{\prime}$ & $001^{\circ} 47.01^{\prime}$ & 113 \\
\hline A22B_0718_SK035 & SK & AM & $38^{\circ} 45.67^{\prime}$ & $001^{\circ} 49.00^{\prime}$ & 103 \\
\hline A22B_0718_SK036 & SK & AM & $38^{\circ} 43.11^{\prime}$ & $001^{\circ} 53.45^{\prime}$ & 479 \\
\hline
\end{tabular}


Table A1. Cont.

\begin{tabular}{|c|c|c|c|c|c|}
\hline Code & Dredge & Area & Latitude (N) & Longitude (E) & Depth (m) \\
\hline A22B_0718_SK038 & SK & $\mathrm{AM}$ & $38^{\circ} 45.89^{\prime}$ & $001^{\circ} 47.48^{\prime}$ & 131 \\
\hline A22B_0718_SK039 & SK & $\mathrm{AM}$ & $38^{\circ} 47.73^{\prime}$ & $001^{\circ} 47.66^{\prime}$ & 121 \\
\hline A22B_0718_SK040 & SK & $\mathrm{AM}$ & $38^{\circ} 45.30^{\prime}$ & $001^{\circ} 48.45^{\prime}$ & 98 \\
\hline A22B_0718_SK041 & SK & $\mathrm{AM}$ & $38^{\circ} 45.65^{\prime}$ & $001^{\circ} 49.60^{\prime}$ & 104 \\
\hline A22B_0718_SK042 & SK & $\mathrm{AM}$ & $38^{\circ} 45.35^{\prime}$ & $001^{\circ} 49.45^{\prime}$ & 105 \\
\hline A22B_0718_SK043 & SK & $\mathrm{AM}$ & $38^{\circ} 44.97^{\prime}$ & $001^{\circ} 49.51^{\prime}$ & 103 \\
\hline A22B_0718_SK045 & SK & $\mathrm{AM}$ & $38^{\circ} 44.86^{\prime}$ & $001^{\circ} 51.03^{\prime}$ & 132 \\
\hline A22B_0718_SK046 & SK & $\mathrm{AM}$ & $38^{\circ} 45.16^{\prime}$ & $001^{\circ} 50.89^{\prime}$ & 124 \\
\hline A22B_0718_SK047 & SK & $\mathrm{AM}$ & $38^{\circ} 45.63^{\prime}$ & $001^{\circ} 51.02^{\prime}$ & 121 \\
\hline A22B_0718_SK048 & SK & $\mathrm{AM}$ & $38^{\circ} 45.60^{\prime}$ & $001^{\circ} 51.68^{\prime}$ & 142 \\
\hline A22B_0718_SK049 & SK & $\mathrm{AM}$ & $38^{\circ} 45.08^{\prime}$ & $001^{\circ} 52.62^{\prime}$ & 436 \\
\hline A22B_1019_SK054 & SK & $\mathrm{AM}$ & $38^{\circ} 45.48^{\prime}$ & $001^{\circ} 47.71^{\prime}$ & 115 \\
\hline A22B_1019_SK056 & SK & $\mathrm{AM}$ & $38^{\circ} 46.64^{\prime}$ & $001^{\circ} 52.07^{\prime}$ & 134 \\
\hline A22B_1019_SK084 & SK & $\mathrm{AM}$ & $38^{\circ} 42.08^{\prime}$ & $001^{\circ} 45.77^{\prime}$ & 352 \\
\hline A22B_1019_SK092 & SK & $\mathrm{AM}$ & $38^{\circ} 42.28^{\prime}$ & $001^{\circ} 44.99^{\prime}$ & 385 \\
\hline A22B_1019_SK100 & SK & $\mathrm{AM}$ & $38^{\circ} 48.15^{\prime}$ & $001^{\circ} 44.75^{\prime}$ & 338 \\
\hline A22B_1019_SK102 & SK & $\mathrm{AM}$ & $38^{\circ} 4815^{\prime}$ & $001^{\circ} 44.98^{\prime}$ & 335 \\
\hline A22B_1019_SK106 & SK & $\mathrm{AM}$ & $38^{\circ} 4712^{\prime}$ & $001^{\circ} 51.38^{\prime}$ & 130 \\
\hline A22B_0820_SK18 & SK & $\mathrm{AM}$ & $38^{\circ} 51.26^{\prime}$ & $001^{\circ} 55.29^{\prime}$ & 490 \\
\hline A22B_0820_BC20 & $\mathrm{BC}$ & $\mathrm{AM}$ & $38^{\circ} 48.48^{\prime}$ & $002^{\circ} 00.35^{\prime}$ & 667 \\
\hline A22B_0820_SK21 & SK & $\mathrm{AM}$ & $38^{\circ} 49.98^{\prime}$ & $001^{\circ} 53.48^{\prime}$ & 506 \\
\hline A22B_0820_SK22 & SK & $\mathrm{AM}$ & $38^{\circ} 52.34^{\prime}$ & $001^{\circ} 51.79^{\prime}$ & 430 \\
\hline A22B_0820_BC23 & $\mathrm{BC}$ & $\mathrm{AM}$ & $38^{\circ} 50.30^{\prime}$ & $001^{\circ} 45.87^{\prime}$ & 341 \\
\hline A22B_0820_SK31 & SK & $\mathrm{AM}$ & $38^{\circ} 40.22^{\prime}$ & $001^{\circ} 47.86^{\prime}$ & 441 \\
\hline A22B_0820_SK33 & SK & $\mathrm{AM}$ & $38^{\circ} 42.19^{\prime}$ & $001^{\circ} 57.34^{\prime}$ & 664 \\
\hline A22B_0718_SK053 & SK & EB & $38^{\circ} 44.21^{\prime}$ & $002^{\circ} 30.09$ & 109 \\
\hline A22B_0718_SK054 & SK & $\mathrm{EB}$ & $38^{\circ} 44.21^{\prime}$ & $002^{\circ} 30.15$ & 107 \\
\hline A22B_0718_SK055 & SK & EB & $38^{\circ} 44.23^{\prime}$ & $002^{\circ} 30.27$ & 104 \\
\hline A22B_0718_SK056 & SK & EB & $38^{\circ} 44.37^{\prime}$ & $002^{\circ} 30.18$ & 108 \\
\hline A22B_0718_SK057 & SK & $\mathrm{EB}$ & $38^{\circ} 44.43^{\prime}$ & $002^{\circ} 30.24$ & 107 \\
\hline A22B_0718_SK059 & SK & EB & $38^{\circ} 44.11^{\prime}$ & $002^{\circ} 29.52$ & 128 \\
\hline A22B_0718_SK064 & SK & EB & $38^{\circ} 44.94^{\prime}$ & $002^{\circ} 30.82$ & 134 \\
\hline A22B_0718_SK065 & SK & $\mathrm{EB}$ & $38^{\circ} 43.17^{\prime}$ & $002^{\circ} 29.42$ & 147 \\
\hline A22B_0718_SK070 & SK & $\mathrm{EB}$ & $38^{\circ} 41.83^{\prime}$ & $002^{\circ} 28.00$ & 149 \\
\hline A22B_0718_SK071 & SK & EB & $38^{\circ} 41.17^{\prime}$ & $002^{\circ} 28.11$ & 153 \\
\hline A22B_0718_SK072 & SK & EB & $38^{\circ} 42.05^{\prime}$ & $002^{\circ} 29.79$ & 278 \\
\hline A22B_0718_SK073 & SK & EB & $38^{\circ} 42.44^{\prime}$ & $002^{\circ} 29.96$ & 152 \\
\hline A22B_0718_SK074 & SK & $\mathrm{EB}$ & $38^{\circ} 42.45^{\prime}$ & $002^{\circ} 29.53$ & 152 \\
\hline A22B_0718_BC080 & $\mathrm{BC}$ & EB & $38^{\circ} 46.86^{\prime}$ & $002^{\circ} 31.12^{\prime}$ & 320 \\
\hline A22B_0718_BC082 & $\mathrm{BC}$ & EB & $38^{\circ} 43.60^{\prime}$ & $002^{\circ} 28.25^{\prime}$ & 399 \\
\hline
\end{tabular}


Table A1. Cont.

\begin{tabular}{|c|c|c|c|c|c|}
\hline Code & Dredge & Area & Latitude (N) & Longitude (E) & Depth (m) \\
\hline A22B_0718_SK084 & SK & EB & $38^{\circ} 43.17^{\prime}$ & $002^{\circ} 29.45^{\prime}$ & 147 \\
\hline A22B_0718_SK087 & SK & EB & $38^{\circ} 41.24^{\prime}$ & $002^{\circ} 26.61^{\prime}$ & 319 \\
\hline A22B_0718_SK089 & SK & $\mathrm{EB}$ & $38^{\circ} 45.09^{\prime}$ & $002^{\circ} 27.65^{\prime}$ & 583 \\
\hline A22B_1019_SK151 & SK & EB & $38^{\circ} 40.38^{\prime}$ & $002^{\circ} 26.57^{\prime}$ & 394 \\
\hline A22B_1019_SK152 & SK & EB & $38^{\circ} 40.56^{\prime}$ & $002^{\circ} 29.02^{\prime}$ & 486 \\
\hline A22B_1019_SK161 & SK & EB & $38^{\circ} 42.63^{\prime}$ & $002^{\circ} 27.61^{\prime}$ & 320 \\
\hline A22B_1019_SK162 & SK & EB & $38^{\circ} 41.94^{\prime}$ & $002^{\circ} 25.11^{\prime}$ & 575 \\
\hline A22B_1019_SK171 & SK & EB & $38^{\circ} 42.29^{\prime}$ & $002^{\circ} 28.28^{\prime}$ & 153 \\
\hline A22B_1019_SK172 & SK & EB & $38^{\circ} 42.04^{\prime}$ & $002^{\circ} 32.43^{\prime}$ & 727 \\
\hline A22B_1019_SK181 & SK & EB & $38^{\circ} 43.05^{\prime}$ & $002^{\circ} 30.43^{\prime}$ & 147 \\
\hline A22B_1019_SK183 & SK & EB & $38^{\circ} 43.38^{\prime}$ & $002^{\circ} 28.28^{\prime}$ & 423 \\
\hline A22B_1019_SK184 & SK & $\mathrm{EB}$ & $38^{\circ} 43.95^{\prime}$ & $002^{\circ} 31.90^{\prime}$ & 316 \\
\hline A22B_1019_SK185 & SK & $\mathrm{EB}$ & $38^{\circ} 44.05^{\prime}$ & $002^{\circ} 31.17^{\prime}$ & 125 \\
\hline A22B_0820_SK44 & SK & EB & $38^{\circ} 45.76^{\prime}$ & $002^{\circ} 31.25^{\prime}$ & 326 \\
\hline A22B_0820_SK46 & SK & EB & $38^{\circ} 42.15^{\prime}$ & $002^{\circ} 26.74^{\prime}$ & 307 \\
\hline A22B_0820_SK47 & SK & EB & $38^{\circ} 41.24^{\prime}$ & $002^{\circ} 26.03^{\prime}$ & 308 \\
\hline A22B_0820_SK48 & SK & $\mathrm{EB}$ & $38^{\circ} 41.14^{\prime}$ & $002^{\circ} 25.98^{\prime}$ & 349 \\
\hline A22B_0820_BC49 & $\mathrm{BC}$ & EB & $38^{\circ} 40.91^{\prime}$ & $002^{\circ} 25.27^{\prime}$ & 285 \\
\hline A22B_1019_SK174 & SK & $\mathrm{CB}$ & $38^{\circ} 51.89^{\prime}$ & $002^{\circ} 19.68^{\prime}$ & 1060 \\
\hline A22B_1019_SK191 & SK & $\mathrm{CB}$ & $38^{\circ} 53.13^{\prime}$ & $002^{\circ} 22.51^{\prime}$ & 986 \\
\hline A22B_0820_SK02 & SK & $\mathrm{CB}$ & $38^{\circ} 05.48^{\prime}$ & $002^{\circ} 09.48^{\prime}$ & 946 \\
\hline A22B_0820_SK15 & SK & $\mathrm{CB}$ & $38^{\circ} 57.55^{\prime}$ & $002^{\circ} 05.48^{\prime}$ & 950 \\
\hline A22B_0820_SK37 & SK & $\mathrm{CB}$ & $38^{\circ} 52.80^{\prime}$ & $002^{\circ} 05.91^{\prime}$ & 852 \\
\hline A22B_0820_SK38 & SK & $\mathrm{CB}$ & $38^{\circ} 52.62^{\prime}$ & $002^{\circ} 08.09^{\prime}$ & 924 \\
\hline A22B_0820_SK39 & SK & $\mathrm{CB}$ & $38^{\circ} 50.90^{\prime}$ & $002^{\circ} 13.69^{\prime}$ & 1044 \\
\hline A22B_0718_SK002 & SK & $\mathrm{SO}$ & $38^{\circ} 57.84^{\prime}$ & $002^{\circ} 00.11^{\prime}$ & 286 \\
\hline A22B_0718_SK003 & SK & $\mathrm{SO}$ & $38^{\circ} 57.57^{\prime}$ & $001^{\circ} 58.45^{\prime}$ & 291 \\
\hline A22B_0718_SK004 & SK & $\mathrm{SO}$ & $38^{\circ} 59.35^{\prime}$ & $001^{\circ} 59.44^{\prime}$ & 627 \\
\hline A22B_0718_SK006 & SK & $\mathrm{SO}$ & $38^{\circ} 56.28^{\prime}$ & $001^{\circ} 57.99^{\prime}$ & 281 \\
\hline A22B_0718_SK007 & SK & $\mathrm{SO}$ & $38^{\circ} 55.78^{\prime}$ & $001^{\circ} 57.73^{\prime}$ & 265 \\
\hline A22B_0718_SK008 & SK & $\mathrm{SO}$ & $38^{\circ} 54.56^{\prime}$ & $001^{\circ} 57.19^{\prime}$ & 683 \\
\hline A22B_0718_SK009 & SK & $\mathrm{SO}$ & $38^{\circ} 54.31^{\prime}$ & $001^{\circ} 59.45^{\prime}$ & 661 \\
\hline A22B_0718_BC010 & $\mathrm{BC}$ & $\mathrm{SO}$ & $38^{\circ} 58.80^{\prime}$ & $001^{\circ} 59.06^{\prime}$ & 697 \\
\hline A22B_0718_SK013 & SK & $\mathrm{SO}$ & $38^{\circ} 59.36^{\prime}$ & $002^{\circ} 01.33^{\prime}$ & 1062 \\
\hline A22B_0718_SK015 & SK & $\mathrm{SO}$ & $38^{\circ} 57.43^{\prime}$ & $002^{\circ} 00.23^{\prime}$ & 282 \\
\hline A22B_0718_SK016 & SK & SO & $38^{\circ} 57.18^{\prime}$ & $002^{\circ} 00.28^{\prime}$ & 302 \\
\hline A22B_0718_SK017 & SK & $\mathrm{SO}$ & $38^{\circ} 56.52^{\prime}$ & $002^{\circ} 00.49^{\prime}$ & 510 \\
\hline A22B_1019_SK005 & SK & $\mathrm{SO}$ & $38^{\circ} 57.60^{\prime}$ & $001^{\circ} 59.40^{\prime}$ & 292 \\
\hline A22B_1019_SK006 & SK & $\mathrm{SO}$ & $38^{\circ} 57.15^{\prime}$ & $001^{\circ} 58.21^{\prime}$ & 298 \\
\hline A22B_1019_SK016 & SK & $\mathrm{SO}$ & $38^{\circ} 55.36^{\prime}$ & $001^{\circ} 57.38^{\prime}$ & 452 \\
\hline
\end{tabular}


Table A1. Cont.

\begin{tabular}{|c|c|c|c|c|c|}
\hline Code & Dredge & Area & Latitude (N) & Longitude (E) & Depth (m) \\
\hline A22B_1019_SK024 & SK & SO & $38^{\circ} 56.92^{\prime}$ & $001^{\circ} 59.68^{\prime}$ & 296 \\
\hline A22B_1019_SK026 & SK & SO & $38^{\circ} 56.18^{\prime}$ & $001^{\circ} 58.93^{\prime}$ & 446 \\
\hline A22B_0820_SK17 & SK & SO & $38^{\circ} 53.64^{\prime}$ & $001^{\circ} 56.18^{\prime}$ & 688 \\
\hline A22B_0718_SK012 & SK & PK & $38^{\circ} 59.86^{\prime}$ & $001^{\circ} 59.24^{\prime}$ & 793 \\
\hline A22B_1019_SK030 & SK & PK & $38^{\circ} 54.98^{\prime}$ & $002^{\circ} 01.06^{\prime}$ & 786 \\
\hline A22B_1019_SK031 & SK & PK & $38^{\circ} 54.99^{\prime}$ & $002^{\circ} 00.93^{\prime}$ & 780 \\
\hline A22B_1019_SK038 & SK & PK & $38^{\circ} 57.85^{\prime}$ & $001^{\circ} 56.58^{\prime}$ & 617 \\
\hline A22B_1019_SK039 & SK & PK & $38^{\circ} 58.14^{\prime}$ & $001^{\circ} 56.15^{\prime}$ & 633 \\
\hline A22B_1019_SK110 & SK & PK & $38^{\circ} 55.51^{\prime}$ & $001^{\circ} 55.33^{\prime}$ & 667 \\
\hline A22B_1019_SK117 & SK & PK & $38^{\circ} 57.33^{\prime}$ & $001^{\circ} 51.75^{\prime}$ & 587 \\
\hline A22B_1019_SK118 & SK & PK & $38^{\circ} 57.42^{\prime}$ & $001^{\circ} 52.11^{\prime}$ & 638 \\
\hline A22B_1019_BC119 & $\mathrm{BC}$ & PK & $38^{\circ} 59.80^{\prime}$ & $001^{\circ} 53.90^{\prime}$ & 607 \\
\hline A22B_1019_SK121 & SK & PK & $39^{\circ} 00.80^{\prime}$ & $001^{\circ} 56.11^{\prime}$ & 710 \\
\hline A22B_0820_SK05 & SK & PK & $39^{\circ} 05.44^{\prime}$ & $001^{\circ} 57.70^{\prime}$ & 723 \\
\hline A22B_0820_BC08 & $\mathrm{BC}$ & $\mathrm{PK}$ & $38^{\circ} 58.77^{\prime}$ & $001^{\circ} 56.97^{\prime}$ & 656 \\
\hline A22B_0820_BC10 & $\mathrm{BC}$ & PK & $38^{\circ} 59.20^{\prime}$ & $001^{\circ} 53.79^{\prime}$ & 597 \\
\hline A22B_0820_BC12 & $\mathrm{BC}$ & PK & $38^{\circ} 53.38^{\prime}$ & $001^{\circ} 59.53^{\prime}$ & 749 \\
\hline A22B_0820_SK16 & SK & PK & $38^{\circ} 56.34^{\prime}$ & $002^{\circ} 01.88^{\prime}$ & 778 \\
\hline A22B_1019_SK042 & SK & PK & $38^{\circ} 32.80^{\prime}$ & $001^{\circ} 48.44^{\prime}$ & 628 \\
\hline A22B_1019_SK043 & SK & PK & $38^{\circ} 32.96^{\prime}$ & $001^{\circ} 48.72^{\prime}$ & 633 \\
\hline A22B_1019_BC068 & $\mathrm{BC}$ & PK & $38^{\circ} 33.05^{\prime}$ & $001^{\circ} 48.92^{\prime}$ & 630 \\
\hline A22B_1019_SK069 & SK & PK & $38^{\circ} 33.19^{\prime}$ & $001^{\circ} 49.10^{\prime}$ & 630 \\
\hline A22B_1019_BC070 & $\mathrm{BC}$ & PK & $38^{\circ} 32.95^{\prime}$ & $001^{\circ} 49.05^{\prime}$ & 629 \\
\hline A22B_1019_BC076 & $\mathrm{BC}$ & PK & $38^{\circ} 35.74^{\prime}$ & $001^{\circ} 47.50^{\prime}$ & 564 \\
\hline A22B_1019_SK077 & SK & PK & $38^{\circ} 36.01^{\prime}$ & $001^{\circ} 47.82^{\prime}$ & 556 \\
\hline A22B_1019_BC078 & $\mathrm{BC}$ & PK & $38^{\circ} 35.68^{\prime}$ & $001^{\circ} 47.53^{\prime}$ & 560 \\
\hline A22B_0820_BC26 & $\mathrm{BC}$ & PK & $38^{\circ} 40.87^{\prime}$ & $001^{\circ} 41.01^{\prime}$ & 390 \\
\hline A22B_0820_SK30 & SK & PK & $38^{\circ} 38.47^{\prime}$ & $001^{\circ} 43.42^{\prime}$ & 429 \\
\hline A22B_0820_SK32 & SK & PK & $38^{\circ} 36.18^{\prime}$ & $001^{\circ} 53.16^{\prime}$ & 624 \\
\hline A22B_0718_BC076 & $\mathrm{BC}$ & PK & $38^{\circ} 45.58^{\prime}$ & $002^{\circ} 25.86^{\prime}$ & 726 \\
\hline A22B_0718_SK078 & SK & PK & $38^{\circ} 47.57^{\prime}$ & $002^{\circ} 27.27^{\prime}$ & 721 \\
\hline A22B_0718_BC079 & $\mathrm{BC}$ & PK & $38^{\circ} 50.07^{\prime}$ & $002^{\circ} 27.81^{\prime}$ & 770 \\
\hline A22B_1019_SK131 & SK & PK & $38^{\circ} 48.11^{\prime}$ & $002^{\circ} 26.09^{\prime}$ & 739 \\
\hline A22B_1019_SK139 & SK & PK & $38^{\circ} 48.97^{\prime}$ & $002^{\circ} 29.68^{\prime}$ & 735 \\
\hline A22B_1019_SK140 & SK & PK & $38^{\circ} 49.41^{\prime}$ & $002^{\circ} 28.52^{\prime}$ & 431 \\
\hline A22B_1019_SK164 & SK & PK & $38^{\circ} 49.52^{\prime}$ & $002^{\circ} 30.81^{\prime}$ & 759 \\
\hline A22B_1019_BC190 & $\mathrm{BC}$ & PK & $38^{\circ} 53.73^{\prime}$ & $002^{\circ} 29.43^{\prime}$ & 755 \\
\hline A22B_0820_SK45 & SK & PK & $38^{\circ} 45.77^{\prime}$ & $002^{\circ} 33.88^{\prime}$ & 761 \\
\hline A22B_0820_SK51 & SK & PK & $38^{\circ} 40.68^{\prime}$ & $002^{\circ} 25.95^{\prime}$ & 316 \\
\hline A22B_0820_SK52 & SK & PK & $38^{\circ} 38.56^{\prime}$ & $002^{\circ} 18.78^{\prime}$ & 1017 \\
\hline
\end{tabular}


Table A1. Cont.

\begin{tabular}{cccccc}
\hline Code & Dredge & Area & Latitude (N) & Longitude (E) & Depth (m) \\
\hline A22B_0820_SK53 & SK & PK & $38^{\circ} 38.65^{\prime}$ & $002^{\circ} 29.22^{\prime}$ & 1005 \\
\hline A22B_0820_BC54 & BC & PK & $38^{\circ} 39.37^{\prime}$ & $002^{\circ} 22.60^{\prime}$ & 905 \\
\hline A22B_0820_SK57 & SK & PK & $38^{\circ} 53.03^{\prime}$ & $002^{\circ} 27.82^{\prime}$ & 744 \\
\hline A22B_0820_SK58 & SK & PK & $38^{\circ} 49.90^{\prime}$ & $002^{\circ} 24.65^{\prime}$ & 798 \\
\hline A22B_0820_SK59 & SK & PK & $38^{\circ} 48.57^{\prime}$ & $002^{\circ} 21.21^{\prime}$ & 993 \\
\hline A22B_0820_SK60 & SK & PK & $38^{\circ} 47.45^{\prime}$ & $002^{\circ} 19.92^{\prime}$ & 985 \\
\hline A22B_0820_SK62 & SK & PK & $38^{\circ} 43.83^{\prime}$ & $002^{\circ} 20.19^{\prime}$ & 895 \\
\hline
\end{tabular}

\section{Appendix B}

Table A2. Characteristics of the sampling stations carried out with rock dredges in the Mallorca Channel seamounts Ses Olives (SO), Ausias March (AM), and Emile Baudot (EB) during the INTEMARES project. Bathymetric interval shows the initial and final depths of the haul.

\begin{tabular}{|c|c|c|c|c|c|c|c|}
\hline \multirow[b]{2}{*}{ Code } & \multirow[b]{2}{*}{ Area } & \multirow[b]{2}{*}{ Date } & \multicolumn{2}{|c|}{ Setting } & \multicolumn{2}{|c|}{ Hauling } & \multirow[b]{2}{*}{ Depth (m) } \\
\hline & & & Latitude (N) & Longitud (E) & Latitude (N) & Longitud (E) & \\
\hline A22B_0718_DR_014 & $\mathrm{SO}$ & 28 July 2018 & $38^{\circ} 58.97^{\prime}$ & $001^{\circ} 59.97^{\prime}$ & $38^{\circ} 58.74^{\prime}$ & $001^{\circ} 59.98^{\prime}$ & $479-278$ \\
\hline A22B_0718_DR_018 & SO & 28 July 2018 & $38^{\circ} 57.36^{\prime}$ & $002^{\circ} 01.09^{\prime}$ & $38^{\circ} 57.41^{\prime}$ & $002^{\circ} 00.83^{\prime}$ & $263-235$ \\
\hline A22B_0718_DR_019 & SO & 28 July 2018 & $38^{\circ} 57.01^{\prime}$ & $001^{\circ} 59.55^{\prime}$ & $38^{\circ} 57.13^{\prime}$ & $001^{\circ} 59.45^{\prime}$ & $278-285$ \\
\hline A22B_0718_DR_023 & $\mathrm{AM}$ & 30 July 2018 & $38^{\circ} 44.54^{\prime}$ & $001^{\circ} 46.66^{\prime}$ & $38^{\circ} 44.40^{\prime}$ & $001^{\circ} 46.85^{\prime}$ & $106-92$ \\
\hline A22B_0718_DR_024 & $\mathrm{AM}$ & 30 July 2018 & $38^{\circ} 43.98^{\prime}$ & $001^{\circ} 46.54^{\prime}$ & $38^{\circ} 43.99^{\prime}$ & $001^{\circ} 46.28^{\prime}$ & 90 \\
\hline A22B_0718_DR_052 & EB & 3 August 2018 & $38^{\circ} 44.23^{\prime}$ & $002^{\circ} 30.03^{\prime}$ & $38^{\circ} 44.21^{\prime}$ & $002^{\circ} 30.20^{\prime}$ & 109-107 \\
\hline A22B_0718_DR_058 & EB & 3 August 2018 & $38^{\circ} 43.93^{\prime}$ & $002^{\circ} 29.11^{\prime}$ & $38^{\circ} 44.00^{\prime}$ & $002^{\circ} 29.25^{\prime}$ & $131-126$ \\
\hline A22B_0718_DR_062 & EB & 4 August 2018 & $38^{\circ} 45.80^{\prime}$ & $002^{\circ} 34.33^{\prime}$ & $38^{\circ} 45.56^{\prime}$ & $002^{\circ} 34.37^{\prime}$ & $600-556$ \\
\hline A22B_0718_DR_067 & EB & 4 August 2018 & $38^{\circ} 41.54^{\prime}$ & $002^{\circ} 27.56^{\prime}$ & $38^{\circ} 41.66^{\prime}$ & $002^{\circ} 27.97^{\prime}$ & $144-151$ \\
\hline A22B_0718_DR_068 & EB & 4 August 2018 & $38^{\circ} 41.91^{\prime}$ & $002^{\circ} 28.76^{\prime}$ & $38^{\circ} 42.16^{\prime}$ & $002^{\circ} 28.59^{\prime}$ & $125-135$ \\
\hline A22B_0718_DR_086 & EB & 7 August 2018 & $38^{\circ} 40.65^{\prime}$ & $002^{\circ} 25.73^{\prime}$ & $38^{\circ} 40.65^{\prime}$ & $002^{\circ} 25.95^{\prime}$ & $337-309$ \\
\hline A22B_1019_DR_003 & $\mathrm{SO}$ & 11 October 2019 & $38^{\circ} 58.66^{\prime}$ & $001^{\circ} 59.29^{\prime}$ & $38^{\circ} 58.55^{\prime}$ & $001^{\circ} 59.23^{\prime}$ & $287-257$ \\
\hline A22B_1019_DR_008 & $\mathrm{SO}$ & 11 October 2019 & $38^{\circ} 57.65^{\prime}$ & $002^{\circ} 00.89^{\prime}$ & $38^{\circ} 57.70^{\prime}$ & $002^{\circ} 00.97^{\prime}$ & $253-227$ \\
\hline A22B_1019_DR_009 & SO & 11 October 2019 & $38^{\circ} 57.68^{\prime}$ & $002^{\circ} 00.99^{\prime}$ & $38^{\circ} 57.63^{\prime}$ & $002^{\circ} 00.92^{\prime}$ & $253-242$ \\
\hline A22B_1019_DR_014 & $\mathrm{SO}$ & 12 October 2019 & $38^{\circ} 55.61^{\prime}$ & $001^{\circ} 57.63^{\prime}$ & $38^{\circ} 55.69^{\prime}$ & $001^{\circ} 57.61^{\circ}$ & $266-250$ \\
\hline A22B_1019_DR_015 & SO & 12 October 2019 & $38^{\circ} 55.58^{\prime}$ & $001^{\circ} 57.65^{\prime}$ & $38^{\circ} 55.68^{\prime}$ & $001^{\circ} 57.59^{\prime}$ & $268-241$ \\
\hline A22B_1019_DR_114 & $\mathrm{SO}$ & 23 October 2019 & $38^{\circ} 56.99^{\prime}$ & $001^{\circ} 53.23^{\prime}$ & $38^{\circ} 56.93^{\prime}$ & $001^{\circ} 53.03^{\prime}$ & $428-385$ \\
\hline A22B_1019_DR_051 & $\mathrm{AM}$ & 15 October 2019 & $38^{\circ} 44.15^{\prime}$ & $001^{\circ} 49.14^{\prime}$ & $38^{\circ} 44.22^{\prime}$ & $001^{\circ} 49.19^{\prime}$ & 105 \\
\hline A22B_1019_DR_052 & $\mathrm{AM}$ & 15 October 2019 & $38^{\circ} 44.18^{\prime}$ & $001^{\circ} 47.64^{\prime}$ & $38^{\circ} 44.27^{\prime}$ & $001^{\circ} 47.70^{\prime}$ & $91-89$ \\
\hline A22B_1019_DR_053 & $\mathrm{AM}$ & 15 October 2019 & $38^{\circ} 45.05^{\prime}$ & $001^{\circ} 47.68^{\prime}$ & $38^{\circ} 44.95^{\prime}$ & $001^{\circ} 47.79^{\prime}$ & $107-96$ \\
\hline A22B_1019_DR_095 & $\mathrm{AM}$ & 19 October 2019 & $38^{\circ} 47.82^{\prime}$ & $001^{\circ} 52.56^{\prime}$ & $38^{\circ} 47.74^{\prime}$ & $001^{\circ} 52.38^{\prime}$ & $289-217$ \\
\hline A22B_1019_DR_097 & $\mathrm{AM}$ & 19 October 2019 & $38^{\circ} 48.28^{\prime}$ & $001^{\circ} 52.91^{\prime}$ & $38^{\circ} 48.35^{\prime}$ & $001^{\circ} 52.61^{\prime}$ & $458-352$ \\
\hline A22B_1019_DR_103 & $\mathrm{AM}$ & 21 October 2019 & $38^{\circ} 47.43^{\prime}$ & $001^{\circ} 47.17^{\prime}$ & $38^{\circ} 47.27^{\prime}$ & $001^{\circ} 47.22^{\prime}$ & $310-241$ \\
\hline A22B_1019_DR_128 & EB & 24 October 2019 & $38^{\circ} 49.32^{\prime}$ & $002^{\circ} 28.66^{\prime}$ & $38^{\circ} 49.45^{\prime}$ & $002^{\circ} 28.50^{\prime}$ & $607-446$ \\
\hline A22B_1019_DR_132 & EB & 25 October 2019 & $38^{\circ} 46.66^{\prime}$ & $002^{\circ} 27.99^{\prime}$ & $38^{\circ} 46.60^{\prime}$ & $002^{\circ} 28.07^{\prime}$ & $560-524$ \\
\hline A22B_1019_DR_137 & EB & 25 October 2019 & $38^{\circ} 44.85^{\prime}$ & $002^{\circ} 30.28^{\prime}$ & $38^{\circ} 44.83^{\prime}$ & $002^{\circ} 30.19^{\prime}$ & 124,114 \\
\hline A22B_1019_DR_144 & EB & 26 October 2019 & $38^{\circ} 42.78^{\prime}$ & $002^{\circ} 27.72^{\prime}$ & $38^{\circ} 42.65^{\prime}$ & $002^{\circ} 27.82^{\prime}$ & $321-286$ \\
\hline A22B_1019_DR_147 & EB & 26 October 2019 & $38^{\circ} 42.23^{\prime}$ & $002^{\circ} 28.91^{\prime}$ & $38^{\circ} 42.26^{\prime}$ & $002^{\circ} 29.03^{\prime}$ & $126-123$ \\
\hline
\end{tabular}


Table A2. Cont.

\begin{tabular}{|c|c|c|c|c|c|c|c|}
\hline \multirow[b]{2}{*}{ Code } & \multirow[b]{2}{*}{ Area } & \multirow[b]{2}{*}{ Date } & \multicolumn{2}{|c|}{ Setting } & \multicolumn{2}{|c|}{ Hauling } & \multirow[b]{2}{*}{ Depth (m) } \\
\hline & & & Latitude (N) & Longitud (E) & Latitude (N) & Longitud (E) & \\
\hline A22B_1019_DR_165 & EB & 28 October 2019 & $38^{\circ} 46.97^{\prime}$ & $002^{\circ} 31.10^{\prime}$ & $38^{\circ} 46.88^{\prime}$ & $002^{\circ} 31.13^{\prime}$ & $320-312$ \\
\hline A22B_1019_DR_176 & EB & 29 October 2019 & $38^{\circ} 45.28^{\prime}$ & $002^{\circ} 31.50^{\prime}$ & $38^{\circ} 45.23^{\prime}$ & $002^{\circ} 31.48^{\prime}$ & $144-141$ \\
\hline A22B_0720_DR_003 & $\mathrm{SO}$ & 21 July 2020 & $38^{\circ} 56.67^{\prime}$ & $001^{\circ} 59.94^{\prime}$ & $38^{\circ} 56.74^{\prime}$ & $001^{\circ} 59.77^{\prime}$ & $455-288$ \\
\hline A22B_0720_DR_004 & SO & 21 July 2020 & $38^{\circ} 56.39^{\prime}$ & $001^{\circ} 59.03^{\prime}$ & $38^{\circ} 56.30^{\prime}$ & $001^{\circ} 59.05^{\prime}$ & $440-350$ \\
\hline A22B_0720_DR_007 & SO & 21 July 2020 & $38^{\circ} 58.76^{\prime}$ & $001^{\circ} 59.01^{\prime}$ & $38^{\circ} 58.56$ & $001^{\circ} 59.14^{\prime}$ & $384-255$ \\
\hline A22B_0720_DR_008 & $\mathrm{SO}$ & 21 July 2020 & $38^{\circ} 58.165^{\prime}$ & $002^{\circ} 00.67^{\prime}$ & $38^{\circ} 58.20^{\prime}$ & $002^{\circ} 00.43^{\prime}$ & $355-295$ \\
\hline A22B_0720_DR_009 & SO & 21 July 2020 & $38^{\circ} 58.79^{\prime}$ & $002^{\circ} 00.85^{\prime}$ & $38^{\circ} 59.04^{\prime}$ & $002^{\circ} 00.50^{\prime}$ & $673-657$ \\
\hline A22B_0720_DR_012 & $\mathrm{SO}$ & 22 July 2020 & $38^{\circ} 55.91^{\prime}$ & $001^{\circ} 56.09^{\prime}$ & $38^{\circ} 55.87^{\prime}$ & $001^{\circ} 56.43^{\prime}$ & $664-609$ \\
\hline A22B_0720_DR_014 & SO & 22 July 2020 & $38^{\circ} 55.51^{\prime}$ & $001^{\circ} 58.13^{\prime}$ & $38^{\circ} 55.91^{\prime}$ & $001^{\circ} 57.88^{\prime}$ & $395-270$ \\
\hline A22B_0720_DR_015 & SO & 22 July 2020 & $38^{\circ} 56.38^{\prime}$ & $001^{\circ} 59.59^{\prime}$ & $38^{\circ} 56.60^{\prime}$ & $001^{\circ} 59.35^{\prime}$ & $428-287$ \\
\hline A22B_0720_DR_019 & $\mathrm{AM}$ & 23 July 2020 & $38^{\circ} 43.83^{\prime}$ & $001^{\circ} 45.57^{\prime}$ & $38^{\circ} 43.77^{\prime}$ & $001^{\circ} 45.72^{\prime}$ & $112-94$ \\
\hline A22B_0720_DR_020 & $\mathrm{AM}$ & 23 July 2020 & $38^{\circ} 42.87^{\prime}$ & $001^{\circ} 46.47^{\prime}$ & $38^{\circ} 43.19^{\prime}$ & $001^{\circ} 46.47^{\prime}$ & $137-104$ \\
\hline A22B_0720_DR_027 & $\mathrm{AM}$ & 24 July 2020 & $38^{\circ} 47.55^{\prime}$ & $001^{\circ} 52.83^{\prime}$ & $38^{\circ} 47.48^{\prime}$ & $001^{\circ} 52.53^{\prime}$ & $226-195$ \\
\hline A22B_0720_DR_028 & $\mathrm{AM}$ & 24 July 2020 & $38^{\circ} 45.95^{\prime}$ & $001^{\circ} 51.87^{\prime}$ & $38^{\circ} 46.06^{\prime}$ & $001^{\circ} 51.76^{\prime}$ & $142-133$ \\
\hline A22B_0720_DR_030 & $\mathrm{AM}$ & 24 July 2020 & $38^{\circ} 47.31^{\prime}$ & $001^{\circ} 47.01^{\prime}$ & $38^{\circ} 46.97^{\prime}$ & $001^{\circ} 47.13^{\prime}$ & $276-204$ \\
\hline A22B_0720_DR_034 & $\mathrm{AM}$ & 25 July 2020 & $38^{\circ} 46.03^{\prime}$ & $001^{\circ} 49.09^{\prime}$ & $38^{\circ} 45.92^{\prime}$ & $001^{\circ} 49.24^{\prime}$ & $121-105$ \\
\hline A22B_0720_DR_042 & EB & 26 July 2020 & $38^{\circ} 43.54^{\prime}$ & $002^{\circ} 29.28^{\prime}$ & $38^{\circ} 43.63^{\prime}$ & $002^{\circ} 29.10^{\prime}$ & 139 \\
\hline A22B_0720_DR_043 & EB & 26 July 2020 & $38^{\circ} 44.41^{\prime}$ & $002^{\circ} 30.66^{\prime}$ & $38^{\circ} 44.55^{\prime}$ & $002^{\circ} 30.56^{\prime}$ & 116 \\
\hline A22B_0720_DR_046 & EB & 26 July 2020 & $38^{\circ} 42.31^{\prime}$ & $002^{\circ} 30.75^{\prime}$ & $38^{\circ} 42.52^{\prime}$ & $002^{\circ} 30.71^{\prime}$ & $367-235$ \\
\hline A22B_0720_DR_047 & EB & 26 July 2020 & $38^{\circ} 43.84^{\prime}$ & $002^{\circ} 29.40^{\prime}$ & $38^{\circ} 43.94^{\prime}$ & $002^{\circ} 29.28^{\prime}$ & 127 \\
\hline A22B_0720_DR_053 & EB & 27 July 2020 & $38^{\circ} 44.01^{\prime}$ & $002^{\circ} 30.72^{\prime}$ & $38^{\circ} 44.14^{\prime}$ & $002^{\circ} 30.41^{\prime}$ & $107-102$ \\
\hline A22B_0720_DR_054 & EB & 27 July 2020 & $38^{\circ} 43.33^{\prime}$ & $002^{\circ} 30.90^{\prime}$ & $38^{\circ} 43.52^{\prime}$ & $002^{\circ} 30.73^{\prime}$ & $216-124$ \\
\hline A22B_0720_DR_057 & EB & 27 July 2020 & $38^{\circ} 41.72^{\prime}$ & $002^{\circ} 21.88^{\prime}$ & $38^{\circ} 41.56^{\prime}$ & $002^{\circ} 22.10^{\prime}$ & $665-488$ \\
\hline A22B_0720_DR_058 & EB & 27 July 2020 & $38^{\circ} 41.66^{\prime}$ & $002^{\circ} 29.36^{\prime}$ & $38^{\circ} 41.70^{\prime}$ & $002^{\circ} 29.27^{\prime}$ & $195-138$ \\
\hline A22B_0720_DR_059 & EB & 28 July 2020 & $38^{\circ} 42.62^{\prime}$ & $002^{\circ} 36.41^{\prime}$ & $38^{\circ} 42.85^{\prime}$ & $002^{\circ} 36.48^{\prime}$ & $620-550$ \\
\hline A22B_0720_DR_060 & EB & 28 July 2020 & $38^{\circ} 42.59^{\prime}$ & $002^{\circ} 36.63^{\prime}$ & $38^{\circ} 42.71^{\prime}$ & $002^{\circ} 36.29^{\prime}$ & $686-597$ \\
\hline A22B_0720_DR_061 & EB & 28 July 2020 & $38^{\circ} 40.70^{\prime}$ & $002^{\circ} 35.37^{\prime}$ & $38^{\circ} 40.94^{\prime}$ & $002^{\circ} 35.27^{\prime}$ & $1191-1066$ \\
\hline
\end{tabular}

\section{Appendix C}

Table A3. Table characteristics of the sampling stations carried out with beam trawl in the Mallorca Channel seamounts Ses Olives (SO), Ausias March (AM), and Emile Baudot (EB) during the INTEMARES project.

\begin{tabular}{|c|c|c|c|c|c|c|c|c|c|c|}
\hline \multirow[b]{2}{*}{ Code } & \multirow[b]{2}{*}{ Area } & \multirow[b]{2}{*}{ Date } & \multicolumn{3}{|c|}{ Setting } & \multicolumn{3}{|c|}{ Hauling } & \multicolumn{2}{|c|}{ Sampling } \\
\hline & & & Hour & $\begin{array}{l}\text { Latitude } \\
\text { (N) }\end{array}$ & $\begin{array}{l}\text { Longitud } \\
\text { (E) }\end{array}$ & Hour & $\begin{array}{l}\text { Latitude } \\
\text { (N) }\end{array}$ & $\begin{array}{l}\text { Longitud } \\
\text { (E) }\end{array}$ & $\begin{array}{c}\text { Surface } \\
\left(\mathrm{m}^{2}\right)\end{array}$ & $\begin{array}{c}\text { Depth } \\
\text { (m) }\end{array}$ \\
\hline A22B_1019_BT_002 & $\mathrm{SO}$ & 11 October 2019 & $7: 34$ & $38^{\circ} 57.85^{\prime}$ & $001^{\circ} 58.78^{\prime}$ & $7: 52$ & $38^{\circ} 57.49^{\prime}$ & $001^{\circ} 58.49^{\prime}$ & 654 & 295 \\
\hline A22B_1019_BT_004 & SO & 11 October 2019 & $9: 25$ & $38^{\circ} 57.71^{\prime}$ & $001^{\circ} 59.81^{\prime}$ & $9: 43$ & $38^{\circ} 57.55^{\prime}$ & $001^{\circ} 59.19^{\prime}$ & 619 & 293 \\
\hline A22B_1019_BT_007 & $\mathrm{SO}$ & 11 October 2019 & $11: 23$ & $38^{\circ} 57.33^{\prime}$ & $001^{\circ} 59.90^{\prime}$ & $11: 41$ & $38^{\circ} 57.65^{\prime}$ & $001^{\circ} 59.32^{\prime}$ & 520 & 291 \\
\hline A22B_1019_BT_010 & $\mathrm{SO}$ & 11 October 2019 & $14: 25$ & $38^{\circ} 56.79^{\prime}$ & $001^{\circ} 57.71^{\prime}$ & $14: 43$ & $38^{\circ} 56.67^{\prime}$ & $001^{\circ} 57.65^{\prime}$ & 477 & 288 \\
\hline A22B_1019_BT_012 & SO & 12 October 2019 & $6: 52$ & $38^{\circ} 56.36^{\prime}$ & $001^{\circ} 59.14^{\prime}$ & $7: 12$ & $38^{\circ} 55.67^{\prime}$ & $001^{\circ} 58.64^{\prime}$ & 613 & 453 \\
\hline A22B_1019_BT_013 & $\mathrm{SO}$ & 12 October 2019 & $7: 39$ & $38^{\circ} 55.50^{\prime}$ & $001^{\circ} 57.03^{\prime}$ & $8: 01$ & $38^{\circ} 54.98^{\prime}$ & $001^{\circ} 58.14^{\prime}$ & 758 & 504 \\
\hline A22B_1019_BT_027 & $\mathrm{SO}$ & 13 October 2019 & $6: 12$ & $38^{\circ} 56.85^{\prime}$ & $002^{\circ} 00.76^{\prime}$ & $6: 32$ & $38^{\circ} 56.48^{\prime}$ & $001^{\circ} 59.84^{\prime}$ & 480 & 491 \\
\hline A22B_1019_BT_028 & SO & 13 October 2019 & $7: 38$ & $38^{\circ} 56.75^{\prime}$ & $002^{\circ} 01.16^{\prime}$ & $7: 55$ & $38^{\circ} 57.29^{\prime}$ & $002^{\circ} 01.32$ & 487 & 449 \\
\hline A22B_1019_BT_029 & SO & 13 October 2019 & $8: 26$ & $38^{\circ} 56.44^{\prime}$ & $002^{\circ} 01.63^{\prime}$ & $8: 51$ & $38^{\circ} 55.59^{\prime}$ & $002^{\circ} 01.32^{\prime}$ & 272 & 764 \\
\hline
\end{tabular}


Table A3. Cont.

\begin{tabular}{|c|c|c|c|c|c|c|c|c|c|c|}
\hline \multirow[b]{2}{*}{ Code } & \multirow[b]{2}{*}{ Area } & \multirow[b]{2}{*}{ Date } & \multicolumn{3}{|c|}{ Setting } & \multicolumn{3}{|c|}{ Hauling } & \multicolumn{2}{|c|}{ Sampling } \\
\hline & & & Hour & $\begin{array}{l}\text { Latitude } \\
(\mathrm{N})\end{array}$ & $\begin{array}{l}\text { Longitud } \\
\text { (E) }\end{array}$ & Hour & $\begin{array}{l}\text { Latitude } \\
(\mathrm{N})\end{array}$ & $\begin{array}{l}\text { Longitud } \\
\text { (E) }\end{array}$ & $\begin{array}{c}\text { Surface } \\
\left(\mathrm{m}^{2}\right)\end{array}$ & $\begin{array}{c}\text { Depth } \\
\text { (m) }\end{array}$ \\
\hline A22B_1019_BT_036 & SO & 13 October 2019 & $15: 51$ & $38^{\circ} 57.19^{\prime}$ & $001^{\circ} 56.11^{\prime}$ & $16: 18$ & $38^{\circ} 57.99^{\prime}$ & $001^{\circ} 56.67^{\prime}$ & 590 & 619 \\
\hline A22B_1019_BT_049 & $\mathrm{AM}$ & 15 October 2019 & $7: 07$ & $38^{\circ} 43.33^{\prime}$ & $001^{\circ} 49.37^{\prime}$ & $7: 19$ & $38^{\circ} 43.80^{\prime}$ & $001^{\circ} 50.09^{\prime}$ & 697 & 124 \\
\hline A22B_1019_BT_050 & $\mathrm{AM}$ & 15 October 2019 & $7: 49$ & $38^{\circ} 43.42^{\prime}$ & $001^{\circ} 47.90^{\prime}$ & 8:00 & $38^{\circ} 43.58^{\prime}$ & $001^{\circ} 48.39^{\prime}$ & 524 & 102 \\
\hline A22B_1019_BT_055 & $\mathrm{AM}$ & 15 October 2019 & $10: 44$ & $38^{\circ} 45.44^{\prime}$ & $001^{\circ} 47.56^{\prime}$ & $10: 48$ & $38^{\circ} 45.56^{\prime}$ & $001^{\circ} 47.78^{\prime}$ & 425 & 114 \\
\hline A22B_1019_BT_058 & $\mathrm{AM}$ & 15 October 2019 & $12: 40$ & $38^{\circ} 46.54^{\prime}$ & $001^{\circ} 52.09^{\prime}$ & $12: 53$ & $38^{\circ} 47.10^{\prime}$ & $001^{\circ} 52.33^{\prime}$ & 642 & 139 \\
\hline A22B_1019_BT_065 & $\mathrm{AM}$ & 16 October 2019 & $6: 19$ & $38^{\circ} 35.57^{\prime}$ & $001^{\circ} 53.45^{\prime}$ & $6: 47$ & $38^{\circ} 36.83^{\prime}$ & $001^{\circ} 54.40^{\prime}$ & 1679 & 631 \\
\hline A22B_1019_BT_075 & $\mathrm{AM}$ & 17 October 2019 & 8:46 & $38^{\circ} 34.72^{\prime}$ & $001^{\circ} 45.22^{\prime}$ & 9:17 & $38^{\circ} 35.52^{\prime}$ & $001^{\circ} 46.80^{\prime}$ & 2057 & 551 \\
\hline A22B_1019_BT_079 & $\mathrm{AM}$ & 17 October 2019 & $13: 37$ & $38^{\circ} 39.07^{\prime}$ & $001^{\circ} 50.42^{\prime}$ & $14: 11$ & $38^{\circ} 40.02^{\prime}$ & $001^{\circ} 51.82^{\prime}$ & 1850 & 501 \\
\hline A22B_1019_BT_089 & $\mathrm{AM}$ & 18 October 2019 & $14: 10$ & $38^{\circ} 40.71^{\prime}$ & $001^{\circ} 41.94^{\prime}$ & $14: 44$ & $38^{\circ} 41.45^{\prime}$ & $001^{\circ} 43.28^{\prime}$ & 2040 & 410 \\
\hline A22B_1019_BT_093 & $\mathrm{AM}$ & 19 October 2019 & $6: 03$ & $38^{\circ} 48.40^{\prime}$ & $001^{\circ} 48.03^{\prime}$ & $6: 32$ & $38^{\circ} 48.89^{\prime}$ & $001^{\circ} 50.45^{\prime}$ & 1531 & 376 \\
\hline A22B_1019_BT_094 & $\mathrm{AM}$ & 19 October 2019 & $6: 54$ & $38^{\circ} 48.85^{\prime}$ & $001^{\circ} 51.06^{\prime}$ & $7: 21$ & $38^{\circ} 50.02^{\prime}$ & $001^{\circ} 51.21^{\prime}$ & 2123 & 409 \\
\hline A22B_1019_BT_099 & $\mathrm{AM}$ & 19 October 2019 & $12: 25$ & $38^{\circ} 46.20^{\prime}$ & $001^{\circ} 48.91^{\prime}$ & $12: 42$ & $38^{\circ} 46.50^{\prime}$ & $001^{\circ} 49.60^{\prime}$ & 1241 & 131 \\
\hline A22B_1019_BT_101 & $\mathrm{AM}$ & 21 October 2019 & $7: 34$ & $38^{\circ} 48.70^{\prime}$ & $001^{\circ} 42.88^{\prime}$ & $7: 58$ & $38^{\circ} 47.83^{\prime}$ & $001^{\circ} 42.40^{\prime}$ & 1056 & 320 \\
\hline A22B_1019_BT_104 & $\mathrm{AM}$ & 21 October 2019 & $11: 12$ & $38^{\circ} 45.62^{\prime}$ & $001^{\circ} 50.77^{\prime}$ & $11: 25$ & $38^{\circ} 46.09^{\prime}$ & $001^{\circ} 51.14^{\prime}$ & 524 & 116 \\
\hline A22B_1019_BT_109 & $\mathrm{SO}$ & 23 October 2019 & $6: 39$ & $38^{\circ} 53.67^{\prime}$ & $001^{\circ} 55.37^{\prime}$ & $7: 15$ & $38^{\circ} 55.12^{\prime}$ & $001^{\circ} 56.12^{\prime}$ & 2086 & 715 \\
\hline A22B_1019_BT_113 & SO & 23 October 2019 & $10: 25$ & $38^{\circ} 54.41^{\prime}$ & $001^{\circ} 56.72^{\prime}$ & $11: 05$ & $38^{\circ} 53.66^{\prime}$ & $001^{\circ} 58.61^{\prime}$ & 1991 & 697 \\
\hline A22B_1019_BT_122 & $\mathrm{SO}$ & 24 October 2019 & $7: 42$ & $39^{\circ} 00.54^{\prime}$ & $001^{\circ} 55.57^{\prime}$ & $8: 18$ & $38^{\circ} 59.61^{\prime}$ & $001^{\circ} 57.40^{\prime}$ & 2148 & 693 \\
\hline A22B_1019_BT_123 & $\mathrm{SO}$ & 24 October 2019 & $8: 54$ & $38^{\circ} 58.27^{\prime}$ & $001^{\circ} 55.85^{\prime}$ & 9:30 & $38^{\circ} 59.97^{\prime}$ & $001^{\circ} 56.56^{\prime}$ & 2222 & 675 \\
\hline A22B_1019_BT_124 & EB & 24 October 2019 & $13: 37$ & $38^{\circ} 45.11^{\prime}$ & $002^{\circ} 31.16^{\prime}$ & $13: 45$ & $38^{\circ} 45.35^{\prime}$ & $002^{\circ} 31.14^{\prime}$ & 387 & 146 \\
\hline A22B_1019_BT_125 & EB & 24 October 2019 & $14: 18$ & $38^{\circ} 45.61^{\prime}$ & $002^{\circ} 31.66^{\prime}$ & $14: 36$ & $38^{\circ} 46.06^{\prime}$ & $002^{\circ} 30.98^{\prime}$ & 630 & 314 \\
\hline A22B_1019_BT_135 & $\mathrm{EB}$ & 25 October 2019 & $14: 05$ & $38^{\circ} 44.91^{\prime}$ & $002^{\circ} 29.66^{\prime}$ & $14: 16$ & $38^{\circ} 44.53^{\prime}$ & $002^{\circ} 29.27^{\prime}$ & 815 & 153 \\
\hline A22B_1019_BT_136 & $\mathrm{EB}$ & 25 October 2019 & $14: 49$ & $38^{\circ} 42.85^{\prime}$ & $002^{\circ} 29.51^{\prime}$ & $15: 00$ & $38^{\circ} 43.23^{\prime}$ & $002^{\circ} 29.37^{\prime}$ & 689 & 143 \\
\hline A22B_1019_BT_143 & EB & 26 October 2019 & $10: 19$ & $38^{\circ} 47.46^{\prime}$ & $002^{\circ} 30.78^{\prime}$ & $10: 51$ & $38^{\circ} 47.82^{\prime}$ & $002^{\circ} 29.47^{\prime}$ & 1271 & 686 \\
\hline A22B_1019_BT_148 & $\mathrm{EB}$ & 26 October 2019 & $15: 10$ & $38^{\circ} 41.45^{\prime}$ & $002^{\circ} 28.18^{\prime}$ & $15: 20$ & $38^{\circ} 41.15^{\prime}$ & $002^{\circ} 28.03^{\prime}$ & 641 & 147 \\
\hline A22B_1019_BT_149 & EB & 26 October 2019 & $15: 49$ & $38^{\circ} 40.76^{\prime}$ & $002^{\circ} 27.48^{\prime}$ & $16: 08$ & $38^{\circ} 40.96^{\prime}$ & $002^{\circ} 26.83^{\prime}$ & 614 & 277 \\
\hline A22B_1019_BT_156 & EB & 27 October 2019 & $11: 23$ & $38^{\circ} 48.48^{\prime}$ & $002^{\circ} 25.14^{\prime}$ & $12: 03$ & $38^{\circ} 49.89^{\prime}$ & $002^{\circ} 25.70^{\prime}$ & 1360 & 759 \\
\hline A22B_1019_BT_157 & $\mathrm{EB}$ & 27 October 2019 & $14: 00$ & $38^{\circ} 41.41^{\prime}$ & $002^{\circ} 26.95^{\prime}$ & $14: 20$ & $38^{\circ} 42.20^{\prime}$ & $002^{\circ} 27.09^{\prime}$ & 1135 & 288 \\
\hline A22B_1019_BT_158 & EB & 27 October 2019 & $14: 57$ & $38^{\circ} 42.97^{\prime}$ & $002^{\circ} 29.65^{\prime}$ & 15:07 & $38^{\circ} 42.94^{\prime}$ & $002^{\circ} 29.11^{\prime}$ & 524 & 143 \\
\hline A22B_1019_BT_166 & EB & 28 October 2019 & $14: 47$ & $38^{\circ} 44.48^{\prime}$ & $002^{\circ} 28.48^{\prime}$ & $15: 08$ & $38^{\circ} 43.74^{\prime}$ & $002^{\circ} 28.03^{\prime}$ & 1295 & 433 \\
\hline A22B_1019_BT_167 & EB & 28 October 2019 & $15: 44$ & $38^{\circ} 42.54^{\prime}$ & $002^{\circ} 29.77^{\prime}$ & $15: 55$ & $38^{\circ} 42.22^{\prime}$ & $002^{\circ} 29.50^{\prime}$ & 655 & 151 \\
\hline A22B_1019_BT_175 & EB & 29 October 2019 & $11: 47$ & $38^{\circ} 46.07^{\prime}$ & $002^{\circ} 30.15^{\prime}$ & 12:08 & $38^{\circ} 46.53^{\prime}$ & $002^{\circ} 31.10^{\prime}$ & 1182 & 412 \\
\hline A22B_1019_BT_177 & EB & 29 October 2019 & $14: 22$ & $38^{\circ} 44.23^{\prime}$ & $002^{\circ} 28.89^{\prime}$ & $14: 34$ & $38^{\circ} 43.79^{\prime}$ & $002^{\circ} 28.90^{\prime}$ & 644 & 156 \\
\hline A22B_1019_BT_178 & EB & 29 October 2019 & 15:09 & $38^{\circ} 43.21^{\prime}$ & $002^{\circ} 27.37^{\prime}$ & $15: 35$ & $38^{\circ} 43.32^{\prime}$ & $002^{\circ} 26.27^{\prime}$ & 1262 & 555 \\
\hline A22B_1019_BT_188 & EB & 30 October 2019 & $13: 18$ & $38^{\circ} 49.11^{\prime}$ & $002^{\circ} 28.94^{\prime}$ & 13:44 & $38^{\circ} 50.01^{\prime}$ & $002^{\circ} 30.21^{\prime}$ & 2497 & 753 \\
\hline A22B_0718_BT_001 & SO & 27 July 2018 & $6: 40$ & $38^{\circ} 56.80^{\prime}$ & $001^{\circ} 58.54^{\prime}$ & $7: 03$ & $38^{\circ} 57.38^{\prime}$ & $001^{\circ} 59.39^{\prime}$ & 849 & 290 \\
\hline A22B_0718_BT_005 & $\mathrm{SO}$ & 27 July 2018 & $13: 58$ & $38^{\circ} 58.62^{\prime}$ & $001^{\circ} 59.88^{\prime}$ & $14: 18$ & $38^{\circ} 58.12^{\prime}$ & $001^{\circ} 59.24^{\prime}$ & 760 & 259 \\
\hline A22B_0718_BT_020 & $\mathrm{SO}$ & 28 July 2018 & $16: 52$ & $38^{\circ} 56.10^{\prime}$ & $001^{\circ} 58.52^{\prime}$ & $17: 11$ & $38^{\circ} 56.10^{\prime}$ & $001^{\circ} 57.73^{\prime}$ & 691 & 275 \\
\hline A22B_0718_BT_021 & $\mathrm{SO}$ & 28 July 2018 & $18: 48$ & $38^{\circ} 56.59^{\prime}$ & $001^{\circ} 57.03^{\prime}$ & 19:08 & $38^{\circ} 57.26^{\prime}$ & $001^{\circ} 57.31^{\prime}$ & 603 & 489 \\
\hline A22B_0718_BT_022 & $\mathrm{AM}$ & 30 July 2018 & $10: 03$ & $38^{\circ} 44.57^{\prime}$ & $001^{\circ} 46.25^{\prime}$ & $10: 12$ & $38^{\circ} 44.42^{\prime}$ & $001^{\circ} 45.89^{\prime}$ & 692 & 105 \\
\hline A22B_0718_BT_030 & $\mathrm{AM}$ & 30 July 2018 & $14: 12$ & $38^{\circ} 45.47^{\prime}$ & $001^{\circ} 45.58^{\prime}$ & $14: 26$ & $38^{\circ} 45.84^{\prime}$ & $001^{\circ} 46.01^{\prime}$ & 621 & 242 \\
\hline A22B_0718_BT_032 & $\mathrm{AM}$ & 30 July 2018 & $13: 32$ & $38^{\circ} 46.70^{\prime}$ & $001^{\circ} 44.90^{\prime}$ & $13: 49$ & $38^{\circ} 47.09^{\prime}$ & $001^{\circ} 45.45^{\prime}$ & 684 & 319 \\
\hline A22B_0718_BT_037 & $\mathrm{AM}$ & 31 July 2018 & 8:05 & $38^{\circ} 45.85^{\prime}$ & $001^{\circ} 47.26^{\prime}$ & $8: 15$ & $38^{\circ} 45.96^{\prime}$ & $001^{\circ} 47.58^{\prime}$ & 694 & 124 \\
\hline A22B_0718_BT_044 & $\mathrm{AM}$ & 31 July 2018 & $11: 02$ & $38^{\circ} 44.46^{\prime}$ & $001^{\circ} 50.85^{\prime}$ & $11: 13$ & $38^{\circ} 44.85^{\prime}$ & $001^{\circ} 50.95^{\prime}$ & 728 & 122 \\
\hline A22B_0718_BT_050 & $\mathrm{AM}$ & 31 July 2018 & $14: 22$ & $38^{\circ} 42.27^{\prime}$ & $001^{\circ} 52.18^{\prime}$ & $14: 45$ & $38^{\circ} 42.95^{\prime}$ & $001^{\circ} 52.57^{\prime}$ & 729 & 445 \\
\hline A22B_0718_BT_051 & EB & 3 August 2018 & $10: 30$ & $38^{\circ} 44.84^{\prime}$ & $002^{\circ} 30.52^{\prime}$ & $10: 41$ & $38^{\circ} 44.98^{\prime}$ & $002^{\circ} 30.91^{\prime}$ & 713 & 127 \\
\hline A22B_0718_BT_060 & $\mathrm{EB}$ & 3 August 2018 & $17: 18$ & $38^{\circ} 43.38^{\prime}$ & $002^{\circ} 29.64^{\prime}$ & $17: 29$ & $38^{\circ} 43.09^{\prime}$ & $002^{\circ} 29.34^{\prime}$ & 637 & 137 \\
\hline A22B_0718_BT_063 & EB & 4 August 2018 & $10: 54$ & $38^{\circ} 45.96^{\prime}$ & $002^{\circ} 34.56^{\prime}$ & $11: 25$ & $38^{\circ} 46.50^{\prime}$ & $002^{\circ} 35.72^{\prime}$ & 729 & 759 \\
\hline A22B_0718_BT_066 & EB & 4 August 2018 & 14:06 & $38^{\circ} 41.42^{\prime}$ & $002^{\circ} 28.44^{\prime}$ & $14: 19$ & $38^{\circ} 41.12^{\prime}$ & $002^{\circ} 28.03^{\prime}$ & 618 & 146 \\
\hline A22B_0718_BT_069 & $\mathrm{EB}$ & 4 August 2018 & $16: 00$ & $38^{\circ} 41.98^{\prime}$ & $002^{\circ} 28.21^{\prime}$ & $16: 12$ & $38^{\circ} 41.73^{\prime}$ & $002^{\circ} 27.86^{\prime}$ & 755 & 146 \\
\hline A22B_0718_BT_077 & EB & 6 August 2018 & $9: 24$ & $38^{\circ} 46.24^{\prime}$ & $002^{\circ} 26.01^{\prime}$ & $9: 50$ & $38^{\circ} 46.95^{\prime}$ & $002^{\circ} 26.65^{\prime}$ & 740 & 704 \\
\hline
\end{tabular}


Table A3. Cont.

\begin{tabular}{|c|c|c|c|c|c|c|c|c|c|c|}
\hline \multirow[b]{2}{*}{ Code } & \multirow[b]{2}{*}{ Area } & \multirow[b]{2}{*}{ Date } & \multicolumn{3}{|c|}{ Setting } & \multicolumn{3}{|c|}{ Hauling } & \multicolumn{2}{|c|}{ Sampling } \\
\hline & & & Hour & $\begin{array}{l}\text { Latitude } \\
\text { (N) }\end{array}$ & $\begin{array}{l}\text { Longitud } \\
\text { (E) }\end{array}$ & Hour & $\begin{array}{l}\text { Latitude } \\
\text { (N) }\end{array}$ & $\begin{array}{l}\text { Longitud } \\
\text { (E) }\end{array}$ & $\begin{array}{l}\text { Surface } \\
\left(\mathrm{m}^{2}\right)\end{array}$ & $\begin{array}{c}\text { Depth } \\
\text { (m) }\end{array}$ \\
\hline A22B_0718_BT_085 & EB & 7 August 2018 & $8: 12$ & $38^{\circ} 41.92^{\prime}$ & $002^{\circ} 26.71^{\prime}$ & $8: 31$ & $38^{\circ} 41.29^{\prime}$ & $002^{\circ} 26.62^{\prime}$ & 624 & 299 \\
\hline A22B_0718_BT_088 & EB & 7 August 2018 & 11:00 & $38^{\circ} 45.48^{\prime}$ & $002^{\circ} 27.75^{\prime}$ & $11: 23$ & $38^{\circ} 44.74^{\prime}$ & $002^{\circ} 27.44^{\prime}$ & 698 & 574 \\
\hline A22B_0720_BT_001 & SO & 21 July 2020 & $6: 12$ & $38^{\circ} 57.67^{\prime}$ & $002^{\circ} 00.64^{\prime}$ & $6: 33$ & $38^{\circ} 58.25^{\prime}$ & $002^{\circ} 00.00^{\prime}$ & 1443 & 281 \\
\hline A22B_0720_BT_002 & $\mathrm{SO}$ & 21 July 2020 & 7:09 & $38^{\circ} 57.29^{\prime}$ & $002^{\circ} 00.40^{\prime}$ & $7: 31$ & $38^{\circ} 56.96^{\prime}$ & $001^{\circ} 59.60^{\prime}$ & 1229 & 298 \\
\hline A22B_0720_BT_005 & $\mathrm{SO}$ & 21 July 2020 & $11: 31$ & $38^{\circ} 56.57^{\prime}$ & $001^{\circ} 57.25^{\prime}$ & $11: 56$ & $38^{\circ} 55.90^{\prime}$ & $001^{\circ} 56.60^{\prime}$ & 1172 & 405 \\
\hline A22B_0720_BT_006 & SO & 21 July 2020 & $12: 39$ & $38^{\circ} 57.46^{\prime}$ & $001^{\circ} 57.06^{\prime}$ & $13: 16$ & $38^{\circ} 58.28^{\prime}$ & $001^{\circ} 58.16^{\prime}$ & 1901 & 556 \\
\hline A22B_0720_BT_010 & $\mathrm{SO}$ & 22 July 2020 & $6: 06$ & $38^{\circ} 54.47^{\prime}$ & $001^{\circ} 56.28^{\prime}$ & $6: 45$ & $38^{\circ} 55.45^{\prime}$ & $001^{\circ} 56.80^{\prime}$ & 1900 & 697 \\
\hline A22B_0720_BT_011 & $\mathrm{SO}$ & 22 July 2020 & $7: 49$ & $38^{\circ} 55.64^{\prime}$ & $001^{\circ} 55.99^{\prime}$ & $8: 26$ & $38^{\circ} 54.37^{\prime}$ & $001^{\circ} 55.46^{\prime}$ & 1848 & 715 \\
\hline A22B_0720_BT_013 & $\mathrm{SO}$ & 22 July 2020 & $11: 27$ & $38^{\circ} 56.48^{\prime}$ & $001^{\circ} 56.00^{\prime}$ & 12:01 & $38^{\circ} 57.71^{\prime}$ & $001^{\circ} 56.30^{\prime}$ & 1768 & 607 \\
\hline A22B_0720_BT_016 & $\mathrm{AM}$ & 23 July 2020 & $7: 00$ & $38^{\circ} 43.40^{\prime}$ & $001^{\circ} 47.04^{\prime}$ & $7: 14$ & $38^{\circ} 43.25^{\prime}$ & $001^{\circ} 46.64^{\prime}$ & 949 & 99 \\
\hline A22B_0720_BT_017 & $\mathrm{AM}$ & 23 July 2020 & $7: 52$ & $38^{\circ} 45.39^{\prime}$ & $001^{\circ} 47.08^{\prime}$ & $8: 11$ & $38^{\circ} 45.08^{\prime}$ & $001^{\circ} 46.60^{\prime}$ & 1067 & 112 \\
\hline A22B_0720_BT_018 & $\mathrm{AM}$ & 23 July 2020 & $8: 41$ & $38^{\circ} 45.05^{\prime}$ & $001^{\circ} 46.55^{\prime}$ & $8: 57$ & $38^{\circ} 45.27^{\prime}$ & $001^{\circ} 46.90^{\prime}$ & 165 & 113 \\
\hline A22B_0720_BT_021 & $\mathrm{AM}$ & 23 July 2020 & $14: 17$ & $38^{\circ} 44.92^{\prime}$ & $001^{\circ} 50.16^{\prime}$ & $14: 34$ & $38^{\circ} 45.32^{\prime}$ & $001^{\circ} 50.49^{\prime}$ & 477 & 105 \\
\hline A22B_0720_BT_026 & $\mathrm{AM}$ & 24 July 2020 & $9: 11$ & $38^{\circ} 47.16^{\prime}$ & $001^{\circ} 50.76^{\prime}$ & $9: 27$ & $38^{\circ} 47.10^{\prime}$ & $001^{\circ} 51.44^{\prime}$ & 281 & 127 \\
\hline A22B_0720_BT_029 & $\mathrm{AM}$ & 24 July 2020 & $12: 43$ & $38^{\circ} 46.24^{\prime}$ & $001^{\circ} 47.57^{\prime}$ & 13:07 & $38^{\circ} 46.03^{\prime}$ & $001^{\circ} 46.52^{\prime}$ & 1068 & 195 \\
\hline A22B_0720_BT_031 & $\mathrm{AM}$ & 24 July 2020 & $14: 26$ & $38^{\circ} 48.05^{\prime}$ & $001^{\circ} 48.19^{\prime}$ & $15: 24$ & $38^{\circ} 47.72^{\prime}$ & $001^{\circ} 47.08^{\prime}$ & 1138 & 348 \\
\hline A22B_0720_BT_033 & $\mathrm{AM}$ & 25 July 2020 & $6: 57$ & $38^{\circ} 46.73^{\prime}$ & $001^{\circ} 47.67^{\prime}$ & $7: 19$ & $38^{\circ} 47.37^{\prime}$ & $001^{\circ} 48.27^{\prime}$ & 1173 & 225 \\
\hline A22B_0720_BT_035 & $\mathrm{AM}$ & 25 July 2020 & $8: 52$ & $38^{\circ} 44.42^{\prime}$ & $001^{\circ} 43.79^{\prime}$ & $9: 23$ & $38^{\circ} 43.80^{\prime}$ & $001^{\circ} 42.75^{\prime}$ & 849 & 352 \\
\hline A22B_0720_BT_037 & $\mathrm{AM}$ & 25 July 2020 & $11: 15$ & $38^{\circ} 42.86^{\prime}$ & $001^{\circ} 51.53^{\prime}$ & $11: 49$ & $38^{\circ} 42.05^{\prime}$ & $001^{\circ} 50.73^{\prime}$ & 1200 & 363 \\
\hline A22B_0720_BT_038 & EB & 26 July 2020 & $6: 09$ & $38^{\circ} 43.72^{\prime}$ & $002^{\circ} 27.69^{\prime}$ & $6: 38$ & $38^{\circ} 42.52^{\prime}$ & $002^{\circ} 27.67^{\prime}$ & 846 & 511 \\
\hline A22B_0720_BT_039 & $\mathrm{EB}$ & 26 July 2020 & $7: 49$ & $38^{\circ} 44.84^{\prime}$ & $002^{\circ} 28.28^{\prime}$ & $8: 13$ & $38^{\circ} 44.21^{\prime}$ & $002^{\circ} 27.84^{\prime}$ & 936 & 483 \\
\hline A22B_0720_BT_044 & $\mathrm{EB}$ & 26 July 2020 & $11: 57$ & $38^{\circ} 39.11^{\prime}$ & $002^{\circ} 29.45^{\prime}$ & $12: 34$ & $38^{\circ} 38.97^{\prime}$ & $002^{\circ} 27.70^{\prime}$ & 1142 & 680 \\
\hline A22B_0720_BT_045 & EB & 26 July 2020 & $13: 40$ & $38^{\circ} 42.52^{\prime}$ & $002^{\circ} 29.74^{\prime}$ & 14:01 & $38^{\circ} 42.27^{\prime}$ & $002^{\circ} 29.40^{\prime}$ & 178 & 150 \\
\hline A22B_0720_BT_052 & $\mathrm{EB}$ & 27 July 2020 & $8: 30$ & $38^{\circ} 45.54^{\prime}$ & $002^{\circ} 31.59^{\prime}$ & $8: 53$ & $38^{\circ} 45.95^{\prime}$ & $002^{\circ} 30.62^{\prime}$ & 1267 & 297 \\
\hline A22B_0720_BT_055 & EB & 27 July 2020 & 11:42 & $38^{\circ} 39.98^{\prime}$ & $002^{\circ} 28.99^{\prime}$ & 12:08 & $38^{\circ} 40.24^{\prime}$ & $002^{\circ} 27.81^{\prime}$ & 673 & 473 \\
\hline A22B_0720_BT_062 & EB & 28 July 2020 & $12: 20$ & $38^{\circ} 43.25^{\prime}$ & $002^{\circ} 27.82^{\prime}$ & $12: 47$ & $38^{\circ} 44.00^{\prime}$ & $002^{\circ} 27.68^{\prime}$ & 894 & 508 \\
\hline
\end{tabular}

\section{Appendix D}

Table A4. Characteristics of the sampling stations carried out with the experimental bottom trawl GOC-73 in the fishing grounds adjacent to the Mallorca Channel seamounts Ausias March (AM) and Emile Baudot (EB) during the INTEMARES project.

\begin{tabular}{|c|c|c|c|c|c|c|c|c|c|c|}
\hline \multirow[b]{2}{*}{ Code } & \multirow[b]{2}{*}{ Area } & \multirow[b]{2}{*}{ Date } & \multicolumn{3}{|c|}{ Setting } & \multicolumn{3}{|c|}{ Hauling } & \multicolumn{2}{|c|}{ Sampling } \\
\hline & & & Hour & $\begin{array}{l}\text { Latitude } \\
\text { (N) }\end{array}$ & $\begin{array}{l}\text { Longitude } \\
\text { (E) }\end{array}$ & Hour & $\begin{array}{l}\text { Latitude } \\
\text { (N) }\end{array}$ & $\begin{array}{l}\text { Longitude } \\
\text { (E) }\end{array}$ & $\begin{array}{c}\text { Surface } \\
\left(\mathrm{km}^{2}\right)\end{array}$ & $\begin{array}{c}\text { Depth } \\
\text { (m) }\end{array}$ \\
\hline A22B_1019_GOC_040 & $\mathrm{AM}$ & 14 October 2019 & $6: 46$ & $38^{\circ} 36.89^{\prime}$ & $001^{\circ} 55.19^{\prime}$ & $8: 30$ & $38^{\circ} 33.31^{\prime}$ & $001^{\circ} 50.91^{\prime}$ & 0.103084 & 631 \\
\hline A22B_1019_GOC_044 & $\mathrm{AM}$ & 14 October 2019 & $11: 40$ & $38^{\circ} 30.34^{\prime}$ & $001^{\circ} 45.14^{\prime}$ & $13: 25$ & $38^{\circ} 33.05^{\prime}$ & $001^{\circ} 51.71^{\prime}$ & 0.102621 & 663 \\
\hline A22B_1019_GOC_066 & $\mathrm{AM}$ & 16 October 2019 & $7: 36$ & $38^{\circ} 40.94^{\prime}$ & $001^{\circ} 56.27^{\prime}$ & 9:10 & $38^{\circ} 36.23^{\prime}$ & $001^{\circ} 53.57^{\prime}$ & 0.106566 & 619 \\
\hline A22B_1019_GOC_154 & EB & 27 October 2019 & 9:10 & $38^{\circ} 52.46^{\prime}$ & $002^{\circ} 27.08^{\prime}$ & $10: 30$ & $38^{\circ} 51.79^{\prime}$ & $002^{\circ} 26.11^{\prime}$ & 0.071558 & 760 \\
\hline A22B_1019_GOC_155 & EB & 27 October 2019 & $6: 47$ & $38^{\circ} 51.92^{\prime}$ & $002^{\circ} 33.42^{\prime}$ & $8: 10$ & $38^{\circ} 48.95^{\prime}$ & $002^{\circ} 25.94^{\prime}$ & 0.071789 & 755 \\
\hline A22B_1019_GOC_173 & EB & 29 October 2019 & $6: 53$ & $38^{\circ} 47.34^{\prime}$ & $002^{\circ} 13.04^{\prime}$ & $8: 40$ & $38^{\circ} 51.19^{\prime}$ & $002^{\circ} 16.90^{\prime}$ & 0.093264 & 1028 \\
\hline A22B_1019_GOC_186 & EB & 30 October 2019 & $9: 20$ & $38^{\circ} 53.16^{\prime}$ & $002^{\circ} 34.81^{\prime}$ & $11: 00$ & $38^{\circ} 49.24^{\prime}$ & $002^{\circ} 30.41^{\prime}$ & 0.103130 & 759 \\
\hline MEDITS_0620_GOC_108 & EB & 24 June 2020 & $5: 53$ & $38^{\circ} 52.52^{\prime}$ & $002^{\circ} 27.06^{\prime}$ & $7: 11$ & $38^{\circ} 48.31^{\prime}$ & $002^{\circ} 25.72^{\prime}$ & 0.075247 & 746 \\
\hline MEDITS_0620_GOC_109 & $\mathrm{EB}$ & 24 June 2020 & $7: 54$ & $38^{\circ} 47.45^{\prime}$ & $002^{\circ} 24.32^{\prime}$ & $9: 16$ & $38^{\circ} 51.73^{\prime}$ & $002^{\circ} 26.08^{\prime}$ & 0.073746 & 754 \\
\hline MEDITS_0620_GOC_110 & EB & 24 June 2020 & $10: 52$ & $38^{\circ} 46.89^{\prime}$ & $002^{\circ} 26.75^{\prime}$ & $12: 14$ & $38^{\circ} 49.73^{\prime}$ & $002^{\circ} 31.30^{\prime}$ & 0.079473 & 732 \\
\hline MEDITS_0621_GOC_235 & EB & 23 June 2021 & $5: 56$ & $38^{\circ} 53.15^{\prime}$ & $002^{\circ} 34.78^{\prime}$ & $7: 19$ & $38^{\circ} 49.64^{\prime}$ & $002^{\circ} 30.99^{\prime}$ & 0.088226 & 757 \\
\hline MEDITS_0621_GOC_236 & EB & 23 June 2021 & $8: 08$ & $38^{\circ} 52.58^{\prime}$ & $002^{\circ} 30.34^{\prime}$ & 9:30 & $38^{\circ} 48.92^{\prime}$ & $002^{\circ} 26.92^{\prime}$ & 0.088505 & 747 \\
\hline
\end{tabular}


Table A4. Cont.

\begin{tabular}{|c|c|c|c|c|c|c|c|c|c|c|}
\hline \multirow[b]{2}{*}{ Code } & \multirow[b]{2}{*}{ Area } & \multirow[b]{2}{*}{ Date } & \multicolumn{3}{|c|}{ Setting } & \multicolumn{3}{|c|}{ Hauling } & \multicolumn{2}{|c|}{ Sampling } \\
\hline & & & Hour & $\begin{array}{l}\text { Latitude } \\
\text { (N) }\end{array}$ & $\begin{array}{l}\text { Longitud } \\
\text { (E) }\end{array}$ & Hour & $\begin{array}{l}\text { Latitude } \\
\text { (N) }\end{array}$ & $\begin{array}{l}\text { Longitud } \\
\text { (E) }\end{array}$ & $\begin{array}{c}\text { Surface } \\
\left(\mathrm{m}^{2}\right)\end{array}$ & $\begin{array}{c}\text { Depth } \\
\text { (m) }\end{array}$ \\
\hline MEDITS_0821_GOC_003 & $\mathrm{AM}$ & 18 August 2021 & $11: 25$ & $38^{\circ} 34.27^{\prime}$ & $001^{\circ} 39.32^{\prime}$ & $12: 48$ & $38^{\circ} 34.47^{\prime}$ & $001^{\circ} 44.80^{\prime}$ & 0.095555 & 542 \\
\hline MEDITS_0821_GOC_004 & $\mathrm{AM}$ & 18 August 2021 & $13: 44$ & $38^{\circ} 31.08^{\prime}$ & $001^{\circ} 43.56^{\prime}$ & $15: 03$ & $38^{\circ} 32.72^{\prime}$ & $001^{\circ} 48.91^{\prime}$ & 0.950162 & 627 \\
\hline MEDITS_0821_GOC_009 & $\mathrm{AM}$ & 19 August 2021 & 13:01 & $38^{\circ} 56.65^{\prime}$ & $001^{\circ} 49.37^{\prime}$ & $14: 30$ & $38^{\circ} 53.04^{\prime}$ & $001^{\circ} 53.47^{\prime}$ & 0.113673 & 459 \\
\hline MEDITS_0821_GOC_032 & $\mathrm{AM}$ & 25 August 2021 & $5: 59$ & $38^{\circ} 39.40^{\prime}$ & $001^{\circ} 55.89^{\prime}$ & $7: 19$ & $38^{\circ} 43.95^{\prime}$ & $001^{\circ} 56.83^{\prime}$ & 0.087158 & 615 \\
\hline MEDITS_0821_GOC_033 & $\mathrm{AM}$ & 25 August 2021 & 8:05 & $38^{\circ} 45.83^{\prime}$ & $001^{\circ} 53.62^{\prime}$ & $9: 26$ & $38^{\circ} 41.67^{\prime}$ & $001^{\circ} 52.06^{\prime}$ & 0.100025 & 460 \\
\hline MEDITS_0821_GOC_034 & $\mathrm{AM}$ & 25 August 2022 & $10: 59$ & $38^{\circ} 39.17^{\prime}$ & $001^{\circ} 40.08^{\prime}$ & $12: 10$ & $38^{\circ} 42.67^{\prime}$ & $001^{\circ} 42.62^{\prime}$ & 0.088374 & 393 \\
\hline MEDITS_0821_GOC_035 & $\mathrm{AM}$ & 25 August 2021 & $12: 55$ & $38^{\circ} 45.88^{\prime}$ & $001^{\circ} 46.13^{\prime}$ & $13: 45$ & $38^{\circ} 46.91^{\prime}$ & $001^{\circ} 49.38^{\prime}$ & 0.053231 & 237 \\
\hline
\end{tabular}

\section{Appendix E}

Table A5. Characteristics of the sampling stations carried out with the TASIFE photogrammetric sledge (ROTV) in the Mallorca Channel seamounts Ses Olives (SO), Ausias March (AM), and Emile Baudot (EB) during the INTEMARES project.

\begin{tabular}{|c|c|c|c|c|c|c|c|c|c|c|c|}
\hline \multirow[b]{2}{*}{ Code } & \multirow[b]{2}{*}{ Area } & \multirow[b]{2}{*}{ Date } & \multirow[b]{2}{*}{ Hour } & \multicolumn{3}{|c|}{ Initial } & \multicolumn{4}{|c|}{ Final } & \multirow[b]{2}{*}{$\begin{array}{l}\text { Sampling } \\
\text { Area }\left(\mathrm{m}^{2}\right)\end{array}$} \\
\hline & & & & $\begin{array}{c}\text { Latitude } \\
\text { (N) }\end{array}$ & $\begin{array}{l}\text { Longitude } \\
\text { (E) }\end{array}$ & $\begin{array}{l}\text { Depth } \\
\text { (m) }\end{array}$ & Hour & $\begin{array}{l}\text { Latitude } \\
\text { (N) }\end{array}$ & $\begin{array}{l}\text { Longitude } \\
\text { (E) }\end{array}$ & $\begin{array}{l}\text { Depth } \\
\text { (m) }\end{array}$ & \\
\hline TR017 & $\mathrm{SO}$ & 12 October 2019 & $11: 21$ & $38^{\circ} 57.994^{\prime}$ & $01^{\circ} 58.627^{\prime}$ & 283 & $11: 36$ & $38^{\circ} 57.936^{\prime}$ & $01^{\circ} 58.622^{\prime}$ & 288 & 534.00 \\
\hline TR018 & SO & 12 October 2019 & $11: 51$ & $38^{\circ} 57.788^{\prime}$ & $01^{\circ} 59.094^{\prime}$ & 288 & 12:08 & $38^{\circ} 57.726^{\prime}$ & $01^{\circ} 59.238^{\prime}$ & 287 & 602.16 \\
\hline TR019 & SO & 12 October 2019 & $12: 27$ & $38^{\circ} 57.587^{\prime}$ & $01^{\circ} 59.551^{\prime}$ & 287 & $12: 42$ & $38^{\circ} 57.514^{\prime}$ & $01^{\circ} 59.720^{\prime}$ & 286 & 540.34 \\
\hline TR020 & $\mathrm{SO}$ & 12 October 2019 & 13:25 & $38^{\circ} 58.410^{\prime}$ & $02^{\circ} 00.127^{\prime}$ & 280 & 13:45 & $38^{\circ} 58.298^{\prime}$ & $02^{\circ} 00.308^{\prime}$ & 302 & 711.18 \\
\hline TR021 & SO & 12 October 2019 & $14: 18$ & $38^{\circ} 57.399^{\prime}$ & $02^{\circ} 00.888^{\prime}$ & 230 & 14:40 & $38^{\circ} 57.303^{\prime}$ & $02^{\circ} 01.091^{\prime}$ & 326 & 799.34 \\
\hline TR022 & $\mathrm{SO}$ & 12 October 2019 & $15: 17$ & $38^{\circ} 56.960^{\prime}$ & $01^{\circ} 59.600^{\prime}$ & 284 & $15: 37$ & $38^{\circ} 56.862^{\prime}$ & $01^{\circ} 59.802^{\prime}$ & 292 & 687.32 \\
\hline TR032 & SO & 13 October 2019 & 12:07 & $38^{\circ} 58.668^{\prime}$ & $01^{\circ} 58.213^{\prime}$ & 587 & $12: 12$ & $38^{\circ} 58.715^{\prime}$ & $01^{\circ} 58.160^{\prime}$ & 612 & 360.52 \\
\hline TR033 & so & 13 October 2019 & 12:50 & $38^{\circ} 58.600^{\prime}$ & $01^{\circ} 58.240^{\prime}$ & 579 & $12: 58$ & $38^{\circ} 58.678^{\prime}$ & $01^{\circ} 58.205^{\prime}$ & 693 & 326.72 \\
\hline TR034 & SO & 13 October 2019 & 13:31 & $38^{\circ} 58.632^{\prime}$ & $01^{\circ} 58.243^{\prime}$ & 580 & 13:36 & $38^{\circ} 58.660^{\prime}$ & $01^{\circ} 58.205^{\prime}$ & 599 & 187.81 \\
\hline TR035 & $\mathrm{SO}$ & 13 October 2019 & $14: 13$ & $38^{\circ} 58.617^{\prime}$ & $01^{\circ} 58.233^{\prime}$ & 583 & 14:24 & $38^{\circ} 58.662^{\prime}$ & $01^{\circ} 58.170^{\prime}$ & 621 & 335.32 \\
\hline TR045 & AM & 14 October 2019 & $14: 57$ & $38^{\circ} 32.801^{\prime}$ & $01^{\circ} 48.446^{\prime}$ & 624 & 15:12 & $38^{\circ} 32.875^{\prime}$ & $01^{\circ} 48.568^{\prime}$ & 624 & 544.34 \\
\hline TR046 & $\mathrm{AM}$ & 14 October 2019 & 15:35 & $38^{\circ} 33.073^{\prime}$ & $01^{\circ} 48.918^{\prime}$ & 579 & 15:50 & $38^{\circ} 33.140^{\prime}$ & $01^{\circ} 49.035^{\prime}$ & 622 & 545.80 \\
\hline TR047 & $\mathrm{AM}$ & 14 October 2019 & 16:09 & $38^{\circ} 33.277^{\prime}$ & $01^{\circ} 49.333^{\prime}$ & 619 & $16: 24$ & $38^{\circ} 33.354^{\prime}$ & $01^{\circ} 49.468^{\prime}$ & 617 & 609.81 \\
\hline TR059 & $\mathrm{AM}$ & 15 October 2019 & 14:03 & $38^{\circ} 44.644^{\prime}$ & $01^{\circ} 48.533^{\prime}$ & 94 & 14:18 & $38^{\circ} 44.695^{\prime}$ & $01^{\circ} 48.388^{\prime}$ & 92. & 629.58 \\
\hline TR060 & $\mathrm{AM}$ & 15 October 2019 & $14: 48$ & $38^{\circ} 44.846^{\prime}$ & $01^{\circ} 47.938^{\prime}$ & 90 & 15:03 & $38^{\circ} 44.898^{\prime}$ & $01^{\circ} 47.791^{\prime}$ & 94 & 638.56 \\
\hline TR061 & $\mathrm{AM}$ & 15 October 2019 & $15: 21$ & $38^{\circ} 45.040^{\prime}$ & $01^{\circ} 47.380^{\prime}$ & 106 & 15:36 & $38^{\circ} 45.092^{\prime}$ & $01^{\circ} 47.231^{\prime}$ & 107 & 728.32 \\
\hline TR062 & $\mathrm{AM}$ & 15 October 2019 & 16:07 & $38^{\circ} 47.397^{\prime}$ & $01^{\circ} 44.038^{\prime}$ & 88 & $16: 22$ & $38^{\circ} 44.099^{\prime}$ & $01^{\circ} 47.248^{\prime}$ & 87 & 593.34 \\
\hline TR063 & $\mathrm{AM}$ & 15 October 2019 & $16: 40$ & $38^{\circ} 44.265^{\prime}$ & $01^{\circ} 46.819^{\prime}$ & 90 & $16: 55$ & $38^{\circ} 44.322^{\prime}$ & $01^{\circ} 46.675^{\prime}$ & 90 & 634.50 \\
\hline TR064 & $\mathrm{AM}$ & 15 October 2019 & $17: 14$ & $38^{\circ} 44.486^{\prime}$ & $01^{\circ} 46.263^{\prime}$ & 110 & $17: 29$ & $38^{\circ} 44.544^{\prime}$ & $01^{\circ} 46.121^{\prime}$ & 111 & 623.60 \\
\hline TR071 & $\mathrm{AM}$ & 16 October 2019 & $16: 41$ & $38^{\circ} 30.436^{\prime}$ & $01^{\circ} 42.765^{\prime}$ & 669 & 17:01 & $38^{\circ} 30.340^{\prime}$ & $01^{\circ} 42.666^{\prime}$ & 699 & 355.56 \\
\hline TR072 & $\mathrm{AM}$ & 16 October 2019 & 17:03 & $38^{\circ} 30.328^{\prime}$ & $01^{\circ} 42.655^{\prime}$ & 699 & $17: 23$ & $38^{\circ} 30.195^{\prime}$ & $01^{\circ} 42.537^{\prime}$ & 716 & 678.44 \\
\hline TR073 & $\mathrm{AM}$ & 16 October 2019 & $17: 24$ & $38^{\circ} 30.188^{\prime}$ & $01^{\circ} 42.532^{\prime}$ & 717 & $17: 34$ & $38^{\circ} 30.121^{\prime}$ & $01^{\circ} 42.471^{\prime}$ & 727 & 342.86 \\
\hline TR080 & $\mathrm{AM}$ & 17 October 2019 & $15: 21$ & $38^{\circ} 42.782^{\prime}$ & $01^{\circ} 47.863^{\prime}$ & 151 & $15: 41$ & $38^{\circ} 42.619^{\prime}$ & $01^{\circ} 47.867^{\prime}$ & 225 & 633.50 \\
\hline TR081 & $\mathrm{AM}$ & 17 October 2019 & $15: 43$ & $38^{\circ} 42.607^{\prime}$ & $01^{\circ} 47.867^{\prime}$ & 229 & 16:03 & $38^{\circ} 42.441^{\prime}$ & $01^{\circ} 47.872^{\prime}$ & 265 & 638.76 \\
\hline TR082 & $\mathrm{AM}$ & 17 October 2019 & 16:05 & $38^{\circ} 42.435^{\prime}$ & $01^{\circ} 47.872^{\prime}$ & 269 & $16: 25$ & $38^{\circ} 42.259^{\prime}$ & $01^{\circ} 47.876^{\prime}$ & 293 & 638.72 \\
\hline TR086 & $\mathrm{AM}$ & 18 October 2019 & 9:04 & $38^{\circ} 43.671^{\prime}$ & $01^{\circ} 45.650^{\prime}$ & 95 & $9: 24$ & $38^{\circ} 43.676^{\prime}$ & $01^{\circ} 45.436^{\prime}$ & 657 & 656.98 \\
\hline TR087 & $\mathrm{AM}$ & 18 October 2019 & $9: 26$ & $38^{\circ} 43.676^{\prime}$ & $01^{\circ} 45.429^{\prime}$ & 159 & $9: 46$ & $38^{\circ} 43.681^{\prime}$ & $01^{\circ} 45.200^{\prime}$ & 657 & 657.48 \\
\hline TR090 & $\mathrm{AM}$ & 18 October 2019 & $15: 40$ & $38^{\circ} 42.058^{\prime}$ & $01^{\circ} 45.867^{\prime}$ & 346 & 15:55 & $38^{\circ} 42.095^{\prime}$ & $01^{\circ} 45.716^{\prime}$ & 500 & 499.58 \\
\hline TR091 & $\mathrm{AM}$ & 18 October 2019 & $16: 19$ & $38^{\circ} 42.293^{\prime}$ & $01^{\circ} 45.146^{\prime}$ & 367 & $16: 34$ & $38^{\circ} 42.248^{\prime}$ & $01^{\circ} 45.146^{\prime}$ & 482 & 481.60 \\
\hline TR096 & $\mathrm{AM}$ & 19 October 2019 & $9: 23$ & $38^{\circ} 48.338^{\prime}$ & $01^{\circ} 52.670^{\prime}$ & 339 & $9: 43$ & $38^{\circ} 48.285^{\prime}$ & $01^{\circ} 52.880^{\prime}$ & 691 & 691.42 \\
\hline TR098 & $\mathrm{AM}$ & 19 October 2019 & $11: 27$ & $38^{\circ} 47.691^{\prime}$ & $01^{\circ} 52.250^{\prime}$ & 198 & $11: 47$ & $38^{\circ} 47.777^{\prime}$ & $01^{\circ} 52.443^{\prime}$ & 668 & 667.84 \\
\hline
\end{tabular}


Table A5. Cont.

\begin{tabular}{|c|c|c|c|c|c|c|c|c|c|c|c|}
\hline \multirow[b]{2}{*}{ Code } & \multirow[b]{2}{*}{ Area } & \multirow[b]{2}{*}{ Date } & \multicolumn{4}{|c|}{ Initial } & \multicolumn{4}{|c|}{ Final } & \multirow[b]{2}{*}{$\begin{array}{l}\text { Sampling } \\
\text { Area }\left(\mathrm{m}^{2}\right)\end{array}$} \\
\hline & & & Hour & $\begin{array}{l}\text { Latitude } \\
\text { (N) }\end{array}$ & $\begin{array}{l}\text { Longitude } \\
\text { (E) }\end{array}$ & $\begin{array}{l}\text { Depth } \\
\text { (m) }\end{array}$ & Hour & $\begin{array}{l}\text { Latitude } \\
\text { (N) }\end{array}$ & $\begin{array}{l}\text { Longitude } \\
\text { (E) }\end{array}$ & $\begin{array}{l}\text { Depth } \\
\text { (m) }\end{array}$ & \\
\hline TR107 & $\mathrm{AM}$ & 21 October 2019 & $13: 58$ & $38^{\circ} 47.246^{\prime}$ & $01^{\circ} 47.193^{\prime}$ & 234 & $14: 18$ & $38^{\circ} 47.403^{\prime}$ & $01^{\circ} 47.147^{\prime}$ & 303 & 671.60 \\
\hline TR111 & $\mathrm{SO}$ & 23 October 2019 & $8: 59$ & $38^{\circ} 54.672^{\prime}$ & $01^{\circ} 56.847^{\prime}$ & 664 & $9: 19$ & $38^{\circ} 54.562^{\prime}$ & $01^{\circ} 56.722^{\prime}$ & 665 & 1113.30 \\
\hline TR112 & $\mathrm{SO}$ & 23 October 2019 & 9:47 & $38^{\circ} 54.206^{\prime}$ & $01^{\circ} 56.389^{\prime}$ & 681 & $9: 52$ & $38^{\circ} 54.244^{\prime}$ & $01^{\circ} 56.375^{\prime}$ & 680 & 271.34 \\
\hline TR115 & $\mathrm{SO}$ & 23 October 2019 & $14: 16$ & $38^{\circ} 56.829^{\prime}$ & $01^{\circ} 53.156^{\prime}$ & 394 & $14: 36$ & $38^{\circ} 56.827^{\prime}$ & $01^{\circ} 52.944^{\prime}$ & 484 & 889.36 \\
\hline TR116 & $\mathrm{SO}$ & 23 October 2019 & $14: 38$ & $38^{\circ} 56.827^{\prime}$ & $01^{\circ} 52.922^{\prime}$ & 492 & $14: 58$ & $38^{\circ} 56.829^{\prime}$ & $01^{\circ} 52.714^{\prime}$ & 576 & 946.00 \\
\hline TR126 & $\mathrm{EB}$ & 24 October 2019 & $15: 34$ & $38^{\circ} 49.437^{\prime}$ & $02^{\circ} 28.508^{\prime}$ & 426 & $15: 54$ & $38^{\circ} 56.827^{\prime}$ & $01^{\circ} 52.944^{\prime}$ & 580 & 880.22 \\
\hline TR127 & EB & 24 October 2019 & $15: 55$ & $38^{\circ} 49.352^{\prime}$ & $02^{\circ} 28.323^{\prime}$ & 593 & $16: 15$ & $38^{\circ} 49.269^{\prime}$ & $02^{\circ} 28.175^{\prime}$ & 713 & 943.64 \\
\hline TR133 & $\mathrm{EB}$ & 25 October 2019 & $12: 59$ & $38^{\circ} 43.847^{\prime}$ & $02^{\circ} 29.414^{\prime}$ & 128 & $13: 19$ & $38^{\circ} 43.970^{\prime}$ & $02^{\circ} 29.267^{\prime}$ & 125 & 731.20 \\
\hline TR134 & $\mathrm{EB}$ & 25 October 2019 & $13: 22$ & $38^{\circ} 43.256^{\prime}$ & $02^{\circ} 29.094^{\prime}$ & 125 & $13: 42$ & $38^{\circ} 44.095^{\prime}$ & $02^{\circ} 29.094^{\prime}$ & 134 & 724.98 \\
\hline TR145 & EB & 26 October 2019 & $13: 38$ & $38^{\circ} 42.146^{\prime}$ & $02^{\circ} 29.219^{\prime}$ & 131 & $13: 53$ & $38^{\circ} 42.208^{\prime}$ & $02^{\circ} 29.082^{\prime}$ & 123 & 525.56 \\
\hline TR146 & $\mathrm{EB}$ & 26 October 2019 & $14: 02$ & $38^{\circ} 42.245^{\prime}$ & $02^{\circ} 29.000^{\prime}$ & 123 & $14: 17$ & $38^{\circ} 42.307^{\prime}$ & $02^{\circ} 28.862^{\prime}$ & 130 & 516.90 \\
\hline TR159 & EB & 27 October 2019 & $15: 52$ & $38^{\circ} 43.770^{\prime}$ & $02^{\circ} 29.525^{\prime}$ & 126 & $16: 12$ & $38^{\circ} 43.762^{\prime}$ & $02^{\circ} 29.313^{\prime}$ & 128 & 661.86 \\
\hline TR160 & EB & 27 October 2019 & $16: 20$ & $38^{\circ} 43.758^{\prime}$ & $02^{\circ} 29.227^{\prime}$ & 128 & $16: 40$ & $38^{\circ} 43.751^{\prime}$ & $02^{\circ} 29.017^{\prime}$ & 148 & 656.76 \\
\hline TR168 & $\mathrm{EB}$ & 28 October 2019 & $16: 28$ & $38^{\circ} 42.043^{\prime}$ & $02^{\circ} 29.260^{\prime}$ & 138 & $16: 48$ & $38^{\circ} 42.037^{\prime}$ & $02^{\circ} 29.048^{\prime}$ & 131 & 656.56 \\
\hline TR169 & $\mathrm{EB}$ & 28 October 2019 & $16: 58$ & $38^{\circ} 42.034^{\prime}$ & $02^{\circ} 28.945^{\prime}$ & 123 & $17: 18$ & $38^{\circ} 42.027^{\prime}$ & $02^{\circ} 28.738^{\prime}$ & 128 & 631.40 \\
\hline TR179 & EB & 29 October 2019 & $16: 32$ & $38^{\circ} 43.368^{\prime}$ & $02^{\circ} 29.966^{\prime}$ & 131 & $16: 52$ & $38^{\circ} 43.375^{\prime}$ & $02^{\circ} 30.170^{\prime}$ & 124 & 644.68 \\
\hline TR180 & EB & 29 October 2019 & $17: 04$ & $38^{\circ} 43.378^{\prime}$ & $02^{\circ} 30.293^{\prime}$ & 126 & $17: 24$ & $38^{\circ} 43.383^{\prime}$ & $02^{\circ} 30.506^{\prime}$ & 126 & 660.68 \\
\hline
\end{tabular}

\section{Appendix F}

Table A6. Characteristics of the sampling stations carried out with the ROV Liropus 2000 in the Mallorca Channel seamounts Ses Olives (SO), Ausias March (AM), and Emile Baudot (EB) during the INTEMARES project.

\begin{tabular}{|c|c|c|c|c|c|c|c|c|c|c|c|}
\hline \multirow[b]{2}{*}{ Code } & \multirow[b]{2}{*}{ Area } & \multirow[b]{2}{*}{ Date } & \multirow[b]{2}{*}{ Hour } & \multicolumn{2}{|c|}{ Initial } & \multirow[b]{2}{*}{$\begin{array}{l}\text { Depth } \\
\text { (m) }\end{array}$} & \multirow[b]{2}{*}{ Hour } & \multicolumn{2}{|c|}{ Final } & \multirow[b]{2}{*}{$\begin{array}{c}\text { Depth } \\
\text { (m) }\end{array}$} & \multirow[b]{2}{*}{$\begin{array}{l}\text { Sampling } \\
\text { Area }\left(\mathrm{m}^{2}\right)\end{array}$} \\
\hline & & & & $\begin{array}{l}\text { Latitude } \\
\text { (N) }\end{array}$ & $\begin{array}{l}\text { Longitude } \\
\text { (E) }\end{array}$ & & & $\begin{array}{l}\text { Latitude } \\
\text { (N) }\end{array}$ & $\begin{array}{l}\text { Longitude } \\
\text { (E) }\end{array}$ & & \\
\hline R1_1 & $\mathrm{SO}$ & 21 August 2020 & $12: 38: 25$ & $38^{\circ} 58.98^{\prime}$ & $001^{\circ} 58.78^{\prime}$ & 608 & $14: 47: 27$ & $38^{\circ} 58.72^{\prime}$ & $001^{\circ} 58.18^{\prime}$ & 637 & 784,624 \\
\hline R1_2 & $\mathrm{SO}$ & 21 August 2020 & $15: 33: 42$ & $38^{\circ} 58.73^{\prime}$ & $001^{\circ} 58.18^{\prime}$ & 642 & $16: 21: 43$ & $38^{\circ} 58.99^{\prime}$ & $001^{\circ} 58.78^{\prime}$ & 611 & $1,086,012$ \\
\hline R1_3 & $\mathrm{SO}$ & 21 August 2020 & 16:31:04 & $38^{\circ} 58.96^{\prime}$ & $001^{\circ} 58.78^{\prime}$ & 800 & 16:57:00 & $38^{\circ} 58.92^{\prime}$ & $001^{\circ} 58.67^{\prime}$ & 601 & 188,041 \\
\hline R2_1 & $\mathrm{SO}$ & 22 August 2020 & $8: 40: 40$ & $38^{\circ} 58.95^{\prime}$ & $001^{\circ} 58.81^{\prime}$ & 580 & 9:48:47 & $38^{\circ} 58.69^{\prime}$ & $001^{\circ} 58.20^{\prime}$ & 611 & $1,559,742$ \\
\hline R2_2 & $\mathrm{SO}$ & 22 August 2020 & 10:28:07 & $38^{\circ} 58.76^{\prime}$ & $001^{\circ} 58.08^{\prime}$ & 672 & 11:34:43 & $38^{\circ} 58.65^{\prime}$ & $001^{\circ} 58.20^{\prime}$ & 604 & 229,906 \\
\hline R3 & $\mathrm{SO}$ & 23 August 2020 & $7: 50: 31$ & $38^{\circ} 58.65^{\prime}$ & $001^{\circ} 58.20^{\prime}$ & 605 & 11:42:20 & $38^{\circ} 58.67^{\prime}$ & $001^{\circ} 58.13^{\prime}$ & 640 & 241,508 \\
\hline R4_1 & $\mathrm{SO}$ & 23 August 2020 & 13:58:13 & $38^{\circ} 56.38^{\prime}$ & $001^{\circ} 59.58^{\prime}$ & 423 & 15:40:40 & $38^{\circ} 56.47^{\prime}$ & $001^{\circ} 59.48^{\prime}$ & 280 & 154,396 \\
\hline R4_2 & $\mathrm{SO}$ & 23 August 2020 & 16:14:04 & $38^{\circ} 56.59^{\prime}$ & $001^{\circ} 59.86^{\prime}$ & 454 & 17:10:32 & $38^{\circ} 56.73^{\prime}$ & $001^{\circ} 59.75^{\prime}$ & 289 & 299,956 \\
\hline R5_1 & $\mathrm{SO}$ & 24 August 2020 & 8:09:24 & $38^{\circ} 56.82^{\prime}$ & $002^{\circ} 00.35^{\prime}$ & 443 & 9:24:59 & $38^{\circ} 57.00^{\prime}$ & $002^{\circ} 00.24^{\prime}$ & 298 & 323,297 \\
\hline R5_2 & $\mathrm{SO}$ & 24 August 2020 & 10:07:51 & $38^{\circ} 56.96^{\prime}$ & $002^{\circ} 00.81^{\prime}$ & 374 & $11: 28: 24$ & $38^{\circ} 57.21^{\prime}$ & $002^{\circ} 00.74^{\prime}$ & 254 & 385,623 \\
\hline R6_1 & $\mathrm{SO}$ & 24 August 2020 & 13:38:50 & $38^{\circ} 57.07^{\prime}$ & $001^{\circ} 56.14^{\prime}$ & 606 & 14:45:44 & $38^{\circ} 57.47^{\prime}$ & $001^{\circ} 56.24^{\prime}$ & 605 & 912,376 \\
\hline R6_2 & $\mathrm{SO}$ & 24 August 2020 & 15:39:11 & $38^{\circ} 57.53^{\prime}$ & $001^{\circ} 55.93^{\prime}$ & 645 & 16:53:33 & $38^{\circ} 57.57^{\prime}$ & $001^{\circ} 55.87^{\prime}$ & 624 & 101,768 \\
\hline R7 & $\mathrm{AM}$ & 25 August 2020 & $7: 42: 33$ & $38^{\circ} 45.74^{\prime}$ & $001^{\circ} 46.01^{\prime}$ & 242 & 9:48:00 & $38^{\circ} 45.37^{\prime}$ & $001^{\circ} 46.36^{\prime}$ & 120 & 799,572 \\
\hline R8 & $\mathrm{AM}$ & 25 August 2020 & 10:46:55 & $38^{\circ} 44.44^{\prime}$ & $001^{\circ} 46.34^{\prime}$ & 107 & 12:53:06 & $38^{\circ} 44.13^{\prime}$ & $001^{\circ} 46.73^{\prime}$ & 86 & 719,893 \\
\hline R9 & $\mathrm{AM}$ & 25 August 2020 & 13:40:29 & $38^{\circ} 43.92^{\prime}$ & $001^{\circ} 46.74^{\prime}$ & 85 & 15:10:00 & $38^{\circ} 44.18^{\prime}$ & $001^{\circ} 47.24^{\prime}$ & 85 & 925,759 \\
\hline R10 & $\mathrm{AM}$ & 25 August 2020 & 16:05:07 & $38^{\circ} 45.38^{\prime}$ & $001^{\circ} 45.41^{\prime}$ & 251 & 17:17:51 & $38^{\circ} 45.10^{\prime}$ & $001^{\circ} 45.84^{\prime}$ & 128 & 687,313 \\
\hline R11 & $\mathrm{AM}$ & 26 August 2020 & 7:08:53 & $38^{\circ} 46.96^{\prime}$ & $001^{\circ} 46.68^{\prime}$ & 299 & 8:51:42 & $38^{\circ} 46.85^{\prime}$ & $001^{\circ} 47.00^{\prime}$ & 197 & 528,920 \\
\hline R12 & $\mathrm{AM}$ & 26 August 2020 & 10:06:05 & $38^{\circ} 47.30^{\prime}$ & $001^{\circ} 53.08^{\prime}$ & 445 & 11:39:18 & $38^{\circ} 47.19^{\prime}$ & $001^{\circ} 52.68^{\prime}$ & 215 & 504,425 \\
\hline $\mathrm{R} 13$ & $\mathrm{AM}$ & 26 August 2020 & 12:39:20 & $38^{\circ} 48.37^{\prime}$ & $001^{\circ} 52.95^{\prime}$ & 456 & 14:11:54 & $38^{\circ} 48.43^{\prime}$ & $001^{\circ} 52.65^{\prime}$ & 344 & 435,245 \\
\hline R14 & $\mathrm{AM}$ & 26 August 2020 & 15:44:22 & $38^{\circ} 49.99^{\prime}$ & $001^{\circ} 58.75^{\prime}$ & 647 & 16:39:05 & $38^{\circ} 50.00^{\prime}$ & $001^{\circ} 58.67^{\prime}$ & 630 & 113,915 \\
\hline R15 & EB & 27 August 2020 & 6:48:54 & $38^{\circ} 42.29^{\prime}$ & $002^{\circ} 31.12^{\prime}$ & 546 & $8: 17: 14$ & $38^{\circ} 42.52^{\prime}$ & $002^{\circ} 30.71^{\prime}$ & 233 & 708,701 \\
\hline
\end{tabular}


Table A6. Cont.

\begin{tabular}{|c|c|c|c|c|c|c|c|c|c|c|c|}
\hline \multirow[b]{2}{*}{ Code } & \multirow[b]{2}{*}{ Area } & \multirow[b]{2}{*}{ Date } & \multirow[b]{2}{*}{ Hour } & \multicolumn{2}{|c|}{ Initial } & \multicolumn{6}{|c|}{ Final } \\
\hline & & & & $\begin{array}{l}\text { Latitude } \\
\text { (N) }\end{array}$ & $\begin{array}{l}\text { Longitude } \\
\text { (E) }\end{array}$ & $\begin{array}{c}\text { Depth } \\
\text { (m) }\end{array}$ & Hour & $\begin{array}{l}\text { Latitude } \\
\text { (N) }\end{array}$ & $\begin{array}{l}\text { Longitude } \\
\text { (E) }\end{array}$ & $\begin{array}{l}\text { Depth } \\
\text { (m) }\end{array}$ & $\begin{array}{l}\text { Sampling } \\
\text { Area }\left(\mathrm{m}^{2}\right)\end{array}$ \\
\hline R16 & EB & 27 August 2020 & 9:11:44 & $38^{\circ} 43.10^{\prime}$ & $002^{\circ} 31.25^{\prime}$ & 401 & $12: 01: 00$ & $38^{\circ} 43.15^{\prime}$ & $002^{\circ} 30.46^{\prime}$ & 143 & $1,243,278$ \\
\hline R17 & EB & 27 August 2020 & 13:04:58 & $38^{\circ} 44.03^{\prime}$ & $002^{\circ} 33.01^{\prime}$ & 593 & $14: 58: 32$ & $38^{\circ} 43.89^{\prime}$ & $002^{\circ} 32.67^{\prime}$ & 363 & 475,220 \\
\hline R18 & EB & 27 August 2020 & 16:03:34 & $38^{\circ} 44.75^{\prime}$ & $002^{\circ} 31.87^{\prime}$ & 500 & $17: 05: 37$ & $38^{\circ} 44.76^{\prime}$ & $002^{\circ} 31.85^{\prime}$ & 341 & 557,222 \\
\hline R19 & EB & 28 August 2020 & $7: 01: 25$ & $38^{\circ} 40.64^{\prime}$ & $002^{\circ} 34.84^{\prime}$ & 1140 & $8: 45: 34$ & $38^{\circ} 40.97^{\prime}$ & $002^{\circ} 34.86^{\prime}$ & 1015 & 524,461 \\
\hline R20 & EB & 28 August 2020 & $10: 38: 16$ & $38^{\circ} 42.74^{\prime}$ & $002^{\circ} 37.14^{\prime}$ & 895 & $13: 20: 57$ & $38^{\circ} 42.67^{\prime}$ & $002^{\circ} 36.51^{\prime}$ & 523 & 765,042 \\
\hline R21 & EB & 28 August 2020 & 15:02:34 & $38^{\circ} 47.61^{\prime}$ & $002^{\circ} 32.83^{\prime}$ & 719 & $16: 57: 40$ & $38^{\circ} 47.26^{\prime}$ & $002^{\circ} 32.94^{\prime}$ & 417 & 661,131 \\
\hline $\mathrm{R} 22$ & $\mathrm{~EB}$ & 29 August 2020 & $8: 23: 53$ & $38^{\circ} 43.90^{\prime}$ & $002^{\circ} 27.63^{\prime}$ & 537 & $8: 22: 57$ & $38^{\circ} 43.95^{\prime}$ & $002^{\circ} 28.46^{\prime}$ & 287 & 996,950 \\
\hline R23 & EB & 29 August 2020 & $9: 21: 25$ & $38^{\circ} 44.45^{\prime}$ & $002^{\circ} 29.24^{\prime}$ & 165 & $11: 27: 16$ & $38^{\circ} 44.66^{\prime}$ & $002^{\circ} 29.72^{\prime}$ & 129 & 738,266 \\
\hline R24 & EB & 29 August 2020 & 12:40:32 & $38^{\circ} 44.76^{\prime}$ & $002^{\circ} 29.46^{\prime}$ & 151 & $14: 25: 19$ & $38^{\circ} 44.95^{\prime}$ & $002^{\circ} 29.90^{\prime}$ & 130 & 682,976 \\
\hline R25 & $\mathrm{EB}$ & 29 August 2020 & $15: 31: 19$ & $38^{\circ} 43.91^{\prime}$ & $002^{\circ} 30.16^{\prime}$ & 114 & $17: 06: 42$ & $38^{\circ} 44.14^{\prime}$ & $002^{\circ} 30.60^{\prime}$ & 96 & 652,233 \\
\hline R26_1 & EB & 30 August 2020 & $8: 19: 50$ & $38^{\circ} 52.35^{\prime}$ & $002^{\circ} 30.43^{\prime}$ & 740 & $9: 32: 20$ & $38^{\circ} 52.89^{\prime}$ & $002^{\circ} 30.56^{\prime}$ & 738 & 950,914 \\
\hline $\mathrm{R} 26 \_2$ & EB & 30 August 2020 & 10:24:19 & $38^{\circ} 53.08^{\prime}$ & $002^{\circ} 30.95^{\prime}$ & 732 & $11: 50: 26$ & $38^{\circ} 53.25^{\prime}$ & $002^{\circ} 30.68^{\prime}$ & 515 & 374,714 \\
\hline $\mathrm{R} 27$ & $\mathrm{~EB}$ & 30 August 2020 & $13: 13: 58$ & $38^{\circ} 53.73^{\prime}$ & $002^{\circ} 29.43^{\prime}$ & 753 & $14: 42: 44$ & $38^{\circ} 53.67^{\prime}$ & $002^{\circ} 29.56^{\prime}$ & 700 & 150,203 \\
\hline R28 & $\mathrm{SO}$ & 31 August 2020 & $7: 10: 43$ & $38^{\circ} 55.84^{\prime}$ & $001^{\circ} 53.59^{\prime}$ & 610 & $8: 35: 27$ & $38^{\circ} 55.90^{\prime}$ & $001^{\circ} 53.43^{\prime}$ & 587 & 176,282 \\
\hline R29 & $\mathrm{SO}$ & 31 August 2020 & 9:49:08 & $85^{\circ} 6.974^{\prime}$ & $001^{\circ} 53.57^{\prime}$ & 422 & $11: 41: 24$ & $38^{\circ} 57.02^{\prime}$ & $001^{\circ} 53.20^{\prime}$ & 387 & 424,614 \\
\hline
\end{tabular}




\section{Appendix G}

Table A7. Inventory of species or taxa identified so far from the sampling developed in the Ses Olives, Ausias March, and Emile Baudot seamounts and adjacent bottoms of the Mallorca Channel (Balearic Islands, western Mediterranean) during the INTEMARES project, with beam trawl (BT), the GOC-73 experimental bottom trawl (GOC), rock dredge (RD), and remote operated vehicle (ROV). The area and depth in which the species or taxa have been found as well as their frequency of occurrence are also shown. $\left(^{*}\right)$ Not been taken into account for biodiversity estimations, since they may be species or taxa repetitions.

\begin{tabular}{|c|c|c|c|c|c|c|c|c|}
\hline & \multicolumn{3}{|c|}{ Area } & \multirow[b]{2}{*}{ Depth (m) } & \multicolumn{4}{|c|}{ Sampling method } \\
\hline & SO & AM & EB & & BT & GOC & RD & ROV \\
\hline \multicolumn{9}{|l|}{ CHLOROPHYTA } \\
\hline $\begin{array}{c}\text { Palmophyllum crassum (Naccari) } \\
\text { Rabenhorst, } 1868\end{array}$ & & $X$ & $x$ & 90-128 & 3 & & 15 & $x$ \\
\hline Chlorophyceae & & $x$ & $x$ & $87-146$ & & & & $x$ \\
\hline \multicolumn{9}{|l|}{ OCHROPHYTA } \\
\hline $\begin{array}{c}\text { Halopteris filicina (Grateloup) } \\
\text { Kützing, } 1843\end{array}$ & & $x$ & $x$ & 89-105 & & & 5 & $x$ \\
\hline $\begin{array}{c}\text { Zanardinia typus (Nardo) } \\
\text { P.C.Silva, } 2000\end{array}$ & & $x$ & & 85-106 & & & & $x$ \\
\hline $\begin{array}{c}\text { Zonaria tournefortii (J.V.Lamouroux) } \\
\text { Montagne, } 1846\end{array}$ & & $x$ & & 85-106 & & & & $x$ \\
\hline \multicolumn{9}{|l|}{ RHODOPHYTA } \\
\hline $\begin{array}{c}\text { Aeodes marginata (Roussel) } \\
\text { F.Schmitz, } 1894\end{array}$ & & $x$ & & 90 & & & 7 & \\
\hline $\begin{array}{c}\text { Cryptonemia tuniformis (Bertoloni) } \\
\text { Zanardini, } 1868\end{array}$ & & $x$ & $x$ & 90-124 & 7 & & 6 & \\
\hline Corallinaceae & & $x$ & $x$ & 98-152 & 37 & & 59 & \\
\hline $\begin{array}{l}\text { cf. Lithophyllum stictiforme (J.E. } \\
\text { Areschoug) Hauck, } 1877\end{array}$ & & $x$ & $x$ & 85-106 & & & & $x$ \\
\hline Lithophyllum spp. & & $x$ & & 85-100 & & & 7 & $x$ \\
\hline Lithothamnion spp. & & & & 85-135 & 37 & & & $x$ \\
\hline cf. Lithothamnion valens Foslie, 1909 & & $x$ & & $85-100$ & & & & $x$ \\
\hline Phymatolithon spp. & & $x$ & $x$ & $85-135$ & 37 & & & $x$ \\
\hline $\begin{array}{l}\text { cf. Mesophyllum alternans (Foslie) } \\
\text { Cabioch \& M.L. Mendoza, } 1998\end{array}$ & & $x$ & & $85-86$ & & & & $x$ \\
\hline $\begin{array}{c}\text { cf. Mesophyllum lichenoides (J.Ellis) } \\
\text { Me.Lemoine, } 1928\end{array}$ & & $x$ & $x$ & 85-135 & & & & $x$ \\
\hline Spongites fruticulosus Kützing, 1841 & & $x$ & & $85-91$ & & & 7 & $x$ \\
\hline Spongites spp. & & $x$ & $x$ & 85-135 & 41 & & & $x$ \\
\hline $\begin{array}{l}\text { cf. Peyssonnelia rosa-marina } \\
\text { Boudouresque \& Denizot, } 1973\end{array}$ & & $x$ & $x$ & 85-135 & & & & $x$ \\
\hline Peyssonnelia spp. Decaisne, 1841 & & $x$ & $x$ & $85-135$ & 7 & & & $x$ \\
\hline $\begin{array}{c}\text { Phyllophora crispa (Hudson) P.S. } \\
\text { Dixon, } 1964\end{array}$ & & $x$ & $x$ & 90-124 & & & 6 & $x$ \\
\hline
\end{tabular}


Table A7. Cont.

\begin{tabular}{|c|c|c|c|c|c|c|c|c|}
\hline & \multicolumn{3}{|c|}{ Area } & \multicolumn{5}{|c|}{ Sampling method } \\
\hline & SO & AM & EB & Depth (m) & BT & GOC & RD & ROV \\
\hline \multicolumn{9}{|l|}{ PORIFERA } \\
\hline Aaptos aaptos (Schmidt, 1864) & & $X$ & $X$ & $108-117$ & 3 & & 6 & $X$ \\
\hline Ancorinidae sp. 1 & $x$ & $x$ & $x$ & $100-511$ & 26 & & 20 & $x$ \\
\hline Ancorinidae sp. 2 & & $x$ & $x$ & $105-150$ & 10 & & & \\
\hline Ancorinidae sp. 3 & & $x$ & $x$ & $105-150$ & 3 & & & \\
\hline Ancorinidae sp. 4 & & & $X$ & $125-125$ & & & 3 & \\
\hline Ancorinidae spp. * & $x$ & $x$ & $x$ & $85-576$ & & & & $x$ \\
\hline Astrophorina sp. 1 & & & $x$ & $117-117$ & & & 5 & \\
\hline Astrophorina sp. 2 & & $X$ & $X$ & $113-150$ & 5 & & & \\
\hline Astrophorina sp. 3 & $x$ & & & 305-305 & & & 8 & \\
\hline Axinella polypoides Schmidt, 1862 & & $x$ & $x$ & 98-99 & 7 & & & $x$ \\
\hline $\begin{array}{l}\text { Axinella spatula Sitjà \& } \\
\text { Maldonado, } 2014\end{array}$ & & $x$ & & $152-152$ & 3 & & & \\
\hline Axinella verrucosa (Esper, 1794) & & $x$ & & $98-127$ & 3 & & 3 & \\
\hline Axinella sp. 1 & & $x$ & $x$ & $153-328$ & 3 & 7 & & \\
\hline Axinella sp. 2 & & $X$ & $X$ & 113-395 & 10 & & & \\
\hline Axinella sp. 3 & & & $x$ & $150-150$ & 3 & & & \\
\hline Axinella sp. 4 & & $x$ & & $99-99$ & 3 & & & \\
\hline Axinella sp. 5 & & $x$ & $x$ & $113-150$ & 3 & & & \\
\hline Axinella sp. 6 & & $x$ & & 99-112 & 7 & & & \\
\hline Axinella spp. * & & $x$ & $x$ & $85-362$ & & & & $x$ \\
\hline Biemna sp. & & $x$ & & $113-113$ & 3 & & & \\
\hline Bubaris sp. 1 & $x$ & $x$ & $x$ & $143-523$ & 22 & & 12 & \\
\hline Bubaris sp. 2 & & $x$ & & $98-98$ & 3 & & & \\
\hline Calcarea sp. 1 & $X$ & $\mathrm{X}$ & $X$ & $105-297$ & 6 & & & \\
\hline Calcarea sp. 2 & & $x$ & $x$ & $105-150$ & 3 & & & \\
\hline Calcarea sp. 3 & & $X$ & & $99-99$ & 3 & & & \\
\hline Calyx cf. tufa (Ridley \& Dendy, 1886) & & $x$ & & $112-113$ & 7 & & & $x$ \\
\hline Cladocroce sp. & & & $x$ & $277-412$ & 10 & & & $x$ \\
\hline Cladorhiza abyssicola Sars, 1872 & $x$ & $x$ & $x$ & $377-715$ & 13 & & & \\
\hline Clathrina sp. & & $x$ & & $121-121$ & & & 7 & \\
\hline Craniella sp. & & & $x$ & $117-117$ & & & 5 & \\
\hline Crella (Crella) sp. & & $x$ & & $105-105$ & 3 & & & \\
\hline Crella (Yvesia) sp. & & $x$ & & $112-112$ & 3 & & & \\
\hline Darwinellidae sp. & & $x$ & $x$ & 99-277 & 23 & & 14 & \\
\hline Desmacella annexa Schmidt, 1870 & $x$ & $x$ & $x$ & $112-756$ & 25 & 17 & & \\
\hline Desmacella inornata (Bowerbank, 1866) & $x$ & $x$ & $x$ & $116-757$ & 40 & 7 & 8 & \\
\hline Desmacella sp. & $x$ & & & $607-607$ & 4 & & & \\
\hline Dictyonella sp. & & $x$ & & $105-105$ & 3 & & & \\
\hline Dictyonella spp. & & $x$ & $x$ & $98-143$ & 5 & & 9 & \\
\hline
\end{tabular}


Table A7. Cont.

\begin{tabular}{|c|c|c|c|c|c|c|c|c|}
\hline & \multicolumn{3}{|c|}{ Area } & \multicolumn{5}{|c|}{ Sampling method } \\
\hline & SO & AM & EB & Depth (m) & BT & GOC & RD & ROV \\
\hline Diplastrella bistellata (Schmidt, 1862) & & $x$ & & $105-105$ & 3 & & & $x$ \\
\hline Dragmatella aberrans (Topsent, 1890) & $x$ & $x$ & $x$ & $127-412$ & 22 & & 14 & \\
\hline Dysidea sp. & & & $\mathrm{X}$ & $117-117$ & & & 5 & \\
\hline Eurypon sp. & & $x$ & & 99 & 3 & & & \\
\hline $\begin{array}{c}\text { Foraminospongia balearica Díaz, } \\
\text { Ramírez-Amaro \& Ordines, } 2021\end{array}$ & & $x$ & $x$ & $87-170$ & 40 & & 25 & $x$ \\
\hline $\begin{array}{c}\text { Foraminospongia minuta Díaz, } \\
\text { Ramírez-Amaro \& Ordines, } 2021\end{array}$ & $X$ & & & $288-318$ & & & 8 & \\
\hline Geodiidae sp. 1 & & $x$ & $x$ & 98-150 & 7 & & 5 & $x$ \\
\hline Geodiidae sp. 2 & & $x$ & $x$ & 99-127 & 14 & & 5 & $x$ \\
\hline Geodiidae sp. 3 & & & $x$ & $150-150$ & 3 & & & \\
\hline Geodiidae sp. 4 & & $X$ & $\mathrm{X}$ & $105-105$ & 3 & & & \\
\hline Geodiidae sp. 5 & & $x$ & & $105-105$ & 3 & & & \\
\hline Geodiidae sp. 6 & & $x$ & $x$ & $105-150$ & 3 & & & \\
\hline Geodiidae sp. 7 & & & $x$ & $141-166$ & & & 10 & \\
\hline Geodiidae sp. 8 & & $x$ & $x$ & 98-147 & 8 & & 14 & \\
\hline Geodiidae sp. 9 & & & $x$ & $146-146$ & 3 & & & \\
\hline Spongosorites spp. * & & $x$ & $x$ & $100-286$ & & & & $x$ \\
\hline Halichondriidae sp. 1 & & & $X$ & 105-105 & & & 5 & \\
\hline Halichondriidae sp. 2 & & & $x$ & $511-511$ & 3 & & & \\
\hline $\begin{array}{l}\text { Haliclona (Soestella) fimbriata Bertolino } \\
\text { \& Pansini, } 2015\end{array}$ & $x$ & & & $143-133$ & & & & $x$ \\
\hline $\begin{array}{l}\text { Haliclona poecillastroides } \\
\text { (Vacelet, 1969) }\end{array}$ & $X$ & $x$ & $X$ & $98-402$ & 20 & & 20 & $x$ \\
\hline $\begin{array}{c}\text { Haliclona (Rhizoniera) rhizophora } \\
\text { (Vacelet, 1969) }\end{array}$ & $x$ & $x$ & $x$ & $225-405$ & 5 & & & \\
\hline Haliclona sp. 1 & & $x$ & & 99-99 & 3 & & & \\
\hline Haliclona sp. 2 & & $x$ & & $127-127$ & 3 & & & \\
\hline Haliclona sp. 3 & & $x$ & & $99-99$ & 3 & & & \\
\hline Haliclona sp. 4 & & & $X$ & $150-150$ & 3 & & & \\
\hline Haliclona sp. 5 & & & $x$ & $150-150$ & 3 & & & \\
\hline Haliclona sp. 6 & & $x$ & $x$ & $105-150$ & 3 & & & \\
\hline Haliclona sp. 7 & & $x$ & & $105-105$ & 3 & & & \\
\hline Haliclona sp. 8 & & $X$ & & $105-105$ & 3 & & & \\
\hline Haliclona (Flagellia) sp. & & & $x$ & $143-146$ & 6 & & & \\
\hline Haliclona (Halichoclona) sp. & & $x$ & $x$ & $116-402$ & 10 & & & \\
\hline Hamacantha spp. * & $X$ & $x$ & $x$ & $248-676$ & & & & $X$ \\
\hline Hamacantha (Hamacantha) sp. & & $X$ & $X$ & $143-412$ & 16 & & 7 & \\
\hline $\begin{array}{l}\text { Hamacantha (Vomerula) falcula } \\
\text { (Bowerbank, 1874) }\end{array}$ & & $x$ & & $98-402$ & 14 & & & \\
\hline Hamacantha (Vomerula) sp. 1 & & $X$ & & $267-267$ & & & 7 & \\
\hline Hamacantha (Vomerula) sp. 2 & $x$ & $x$ & $x$ & $150-508$ & 13 & & & \\
\hline
\end{tabular}


Table A7. Cont.

\begin{tabular}{|c|c|c|c|c|c|c|c|c|}
\hline & \multicolumn{3}{|c|}{ Area } & \multicolumn{5}{|c|}{ Sampling method } \\
\hline & SO & AM & EB & Depth (m) & BT & GOC & RD & ROV \\
\hline Hamacantha (Vomerula) sp. 3 & & & $x$ & $674-674$ & 3 & & & \\
\hline Hemiasterella elongata Topsent, 1928 & & $x$ & $\mathrm{X}$ & $113-473$ & 7 & & 7 & \\
\hline Hexadella sp. & & $x$ & $x$ & 98-277 & 25 & & 12 & \\
\hline Hymedesmia (Hymedesmia) sp. 1 & & $x$ & & $99-113$ & 7 & & & \\
\hline Hymedesmia (Hymedesmia) sp. 2 & & $x$ & & $105-105$ & 3 & & & \\
\hline Hymedesmia (Hymedesmia) sp. 3 & & & $x$ & $473-473$ & 3 & & & \\
\hline Keratosa spp. ${ }^{*}$ & & & $x$ & 106 & & & & $x$ \\
\hline Keratosa sp. 1 & & & $x$ & $143-150$ & 10 & & & \\
\hline Keratosa sp. 2 & & & $x$ & $105-150$ & 19 & & 10 & \\
\hline Latrunculia sp. & & $x$ & $\mathrm{X}$ & $121-141$ & & & 6 & \\
\hline $\begin{array}{l}\text { Melonanchora emphysema } \\
\text { (Schmidt, 1875) }\end{array}$ & & $x$ & & $121-121$ & & & 7 & \\
\hline Pachastrella sp. * & & $x$ & & 106 & & & & $x$ \\
\hline Pachastrellidae sp. 1 & & $x$ & $x$ & $104-113$ & 3 & & 3 & \\
\hline Pachastrellidae sp. 2 & $x$ & & & $274-274$ & & & 8 & \\
\hline Pachastrellidae sp. 3 & & $X$ & $x$ & $105-235$ & & & 12 & \\
\hline Pachastrellidae sp. 4 & & & $x$ & $538-538$ & & & 5 & $x$ \\
\hline $\begin{array}{l}\text { Paratimea massutii Díaz, } \\
\text { Ramírez-Amaro \& Ordines, } 2021\end{array}$ & & & $x$ & $155-167$ & 3 & & & \\
\hline Penares sp. * & & $x$ & $x$ & $85-87$ & & & & $x$ \\
\hline Penares helleri (Schmidt, 1864) & & $x$ & $x$ & $100-460$ & 23 & 7 & 6 & $x$ \\
\hline $\begin{array}{c}\text { Petrosia (Petrosia) raphida } \\
\text { Boury-Esnault, Pansini \& Uriz, } 1994\end{array}$ & & $x$ & $x$ & 98-395 & 18 & & & \\
\hline $\begin{array}{l}\text { Petrosia (Strongylophora) vansoesti } \\
\text { Boury-Esnault, Pansini \& Uriz, } 1994\end{array}$ & & $x$ & $x$ & 98-297 & 13 & & 10 & \\
\hline Petrosia ficiformis (Poiret, 1789) & & $X$ & $x$ & $98-150$ & 10 & & 5 & $x$ \\
\hline Phakellia hirondellei Topsent, 1890 & & $X$ & $x$ & $135-147$ & 3 & & 3 & \\
\hline Phakellia robusta Bowerbank, 1866 & $x$ & $x$ & $X$ & 150-297 & 5 & & 12 & $x$ \\
\hline Phakellia ventilabrum (Linnaeus, 1767) & & & $x$ & 140 & & & 1 & $x$ \\
\hline Phakellia sp. & $X$ & & $x$ & $128-242$ & & & 9 & \\
\hline Poecillastra sp. * & & $x$ & $X$ & $150-370$ & & & & $x$ \\
\hline $\begin{array}{l}\text { Poecillastra compressa } \\
\text { (Bowerbank, 1866) }\end{array}$ & $x$ & $x$ & $x$ & $98-511$ & 40 & & 25 & $x$ \\
\hline Polymastia spp. * & & $x$ & $x$ & $237-573$ & & & & $x$ \\
\hline Polymastia sp. 1 & & & $x$ & $473-473$ & 3 & & & \\
\hline Polymastia sp. 2 & & $x$ & & 99-99 & 3 & & & \\
\hline Polymastia sp. 3 & $X$ & & $x$ & $288-674$ & 11 & & & \\
\hline Porifera * & $x$ & $X$ & $x$ & $85-116$ & & & & $x$ \\
\hline Prosuberites sp. 1 & & $X$ & & 99-99 & 3 & & & \\
\hline Pseudotrachya hystrix (Topsent, 1890) & & $x$ & & $138-209$ & & & 14 & \\
\hline
\end{tabular}


Table A7. Cont.

\begin{tabular}{|c|c|c|c|c|c|c|c|c|}
\hline & \multicolumn{3}{|c|}{ Area } & \multicolumn{5}{|c|}{ Sampling method } \\
\hline & SO & $\mathbf{A M}$ & EB & Depth (m) & BT & GOC & RD & ROV \\
\hline $\begin{array}{l}\text { Rhabdobaris implicata } \\
\text { Pulitzer-Finali, } 1983\end{array}$ & & & $x$ & $117-117$ & & & 5 & \\
\hline $\begin{array}{c}\text { Rhizaxinella pyrifera (Delle } \\
\text { Chiaje, 1828) }\end{array}$ & & $X$ & & $225-402$ & 10 & 7 & & \\
\hline Rhizaxinella sp. 1 & & $X$ & $x$ & $150-348$ & 3 & & & \\
\hline Rhizaxinella sp. 2 & $x$ & & & $281-715$ & 8 & & & \\
\hline Scopalinidae & & $X$ & & $99-112$ & 7 & & & \\
\hline Spinularia sp. & $x$ & $x$ & $x$ & $195-688$ & 5 & & & \\
\hline Spongosorites sp. 1 & & $X$ & & $99-99$ & 3 & & & $x$ \\
\hline Spongosorites sp. 2 & & $x$ & & $127-127$ & 3 & & & $x$ \\
\hline Spongosorites sp. 3 & & $x$ & & $127-127$ & 3 & & & \\
\hline Stylocordyla pellita (Topsent, 1904) & & $x$ & $x$ & $297-538$ & 3 & & 6 & $x$ \\
\hline Stylocordyla spp. * & $x$ & $x$ & $\mathrm{X}$ & $286-687$ & & & & $x$ \\
\hline Suberites domuncula (Olivi, 1792) & & $x$ & & $328-328$ & & 7 & & \\
\hline Sympagella sp. 1 & & $X$ & & $352-352$ & 3 & & & \\
\hline Tethya sp. & & $x$ & & $105-134$ & 3 & & & $x$ \\
\hline Tetractinellida * & & & $X$ & $133-169$ & & & & $x$ \\
\hline Thenea muricata (Bowerbank, 1858) & $x$ & $x$ & $x$ & $122-740$ & 48 & 20 & 7 & $x$ \\
\hline Timea sp. & & $x$ & & 98-127 & 10 & & & \\
\hline Topsentia sp. 1 & & $x$ & & 105-105 & 3 & & & \\
\hline Topsentia sp. 2 & & $x$ & & $112-112$ & 3 & & & \\
\hline $\begin{array}{l}\text { Tretodictyum reiswigi Boury-Esnault, } \\
\text { Vacelet \& Chevaldonné, } 2017\end{array}$ & $x$ & & $x$ & $143-511$ & 23 & & & $x$ \\
\hline Tretodictyum spp. * & $x$ & $X$ & $X$ & $236-534$ & & & & $X$ \\
\hline Vulcanellidae sp. & $x$ & $x$ & $X$ & $127-303$ & 3 & & 9 & $x$ \\
\hline \multicolumn{9}{|l|}{ CNIDARIA } \\
\hline Acanthogorgia sp. * & & $X$ & $x$ & $133-337$ & & & & $X$ \\
\hline Actiniaria * & & & $x$ & 546 & & & & $x$ \\
\hline Actiniidae * & & $x$ & $X$ & $590-818$ & & & & $x$ \\
\hline Adamsia carcinopados (Müller, 1776) & & $x$ & $x$ & 98-277 & 30 & & 5 & \\
\hline Adamsia palliata (Fabricius, 1779) & & $x$ & & 98-127 & 10 & & & \\
\hline Alcyonium acaule Marion, 1878 & & $x$ & & 105 & 3 & & & \\
\hline Alcyonium coralloides (Pallas, 1766) & & & $X$ & $105-128$ & & & 15 & \\
\hline Alcyonium palmatum Pallas, 1766 & & $x$ & $x$ & 160 & & & 5 & $x$ \\
\hline Alcyonium sp. * & & & $\mathrm{X}$ & $100-144$ & & & & $X$ \\
\hline Anthozoa * & $x$ & $x$ & $X$ & $146-854$ & & & & $x$ \\
\hline Amphianthus dornii (Koch, 1878) & $x$ & & & 678 & 4 & & & \\
\hline Bathypathes sp. & & & $x$ & $858-875$ & & & & $x$ \\
\hline Bebryce mollis Philippi, 1842 & & $x$ & $x$ & $100-412$ & 12 & & 18 & $x$ \\
\hline Calliactis parasitica (Couch, 1842) & $x$ & $x$ & $x$ & $98-328$ & 23 & 12 & 5 & \\
\hline
\end{tabular}


Table A7. Cont.

\begin{tabular}{|c|c|c|c|c|c|c|c|c|}
\hline & \multicolumn{3}{|c|}{ Area } & \multicolumn{5}{|c|}{ Sampling method } \\
\hline & SO & $\mathbf{A M}$ & EB & Depth (m) & BT & GOC & RD & ROV \\
\hline Callogorgia verticillata (Pallas, 1766) & & & $\mathrm{X}$ & $117-887$ & & & 10 & $x$ \\
\hline Callogorgia sp. * & & & $\mathrm{X}$ & $143-134$ & & & & $x$ \\
\hline $\begin{array}{c}\text { Caryophyllia smithii Stokes \& } \\
\text { Broderip, } 1828\end{array}$ & $X$ & & & 290 & 4 & & & \\
\hline $\begin{array}{c}\text { Caryophyllia(Caryophyllia) calveri } \\
\text { Duncan, } 1873\end{array}$ & & & $\mathrm{X}$ & $531-684$ & & & & $x$ \\
\hline Caryophyllia sp. * & $x$ & & $X$ & $542-874$ & & & & $x$ \\
\hline $\begin{array}{l}\text { Cerianthus membranaceus } \\
\text { (Gmelin, 1791) }\end{array}$ & & $x$ & & 159-299 & & & & $x$ \\
\hline Ceriantharia & $x$ & $x$ & $\mathrm{X}$ & $258-753$ & & & & $x$ \\
\hline $\begin{array}{l}\text { Chironephthya mediterranea } \\
\text { López-González, Grinyó \& Gili, } 2014\end{array}$ & & $x$ & & $226-258$ & & & & $x$ \\
\hline Dendrophyllia sp. & $x$ & & & 642 & & & & $x$ \\
\hline $\begin{array}{l}\text { Dendrophyllia cornigera } \\
\quad \text { (Lamarck, 1816) }\end{array}$ & & $x$ & $\mathrm{X}$ & $297-372$ & & & & $x$ \\
\hline Ellisella flagellum (Johnson, 1863) & & & $X$ & $128-293$ & & & 15 & $x$ \\
\hline Eunicella singularis cf. (Esper, 1791) & & $x$ & $x$ & $96-112$ & & & & $X$ \\
\hline $\begin{array}{l}\text { Funiculina quadrangularis } \\
\text { (Pallas, 1766) }\end{array}$ & & $x$ & $\mathrm{X}$ & $137-146$ & 6 & 7 & & $x$ \\
\hline Hydrozoa * & & $x$ & $x$ & $88-106$ & & & & $x$ \\
\hline Isidella elongata (Esper, 1788) & $x$ & & $\mathrm{X}$ & $146-715$ & 12 & & 8 & $x$ \\
\hline Lafoea dumosa (Fleming, 1820) & $x$ & & $X$ & $312-757$ & 4 & & 5 & \\
\hline Leiopathes glaberrima (Esper, 1792) & & & $\mathrm{X}$ & 500 & & & & $X$ \\
\hline Madrepora oculata Linnaeus, 1758 & & $x$ & & $338-372$ & & & & $x$ \\
\hline $\begin{array}{l}\text { cf. Muriceides lepida Carpine \& } \\
\text { Grasshoff, } 1975\end{array}$ & & $x$ & & $173-255$ & & & & $x$ \\
\hline cf. Nicella granifera (Kölliker, 1865) & $x$ & $x$ & $\mathrm{x}$ & $145-887$ & & & & $x$ \\
\hline $\begin{array}{l}\text { Paralcyonium spinulosum (Delle } \\
\text { Chiaje, 1822) }\end{array}$ & & $x$ & $\mathrm{X}$ & $88-144$ & & & & $x$ \\
\hline Paramuricea hirsuta (Gray, 1857) & & $x$ & & $344-380$ & & & & $X$ \\
\hline $\begin{array}{c}\text { Parazoanthus sp. Haddon \& } \\
\text { Shackleton, } 1891\end{array}$ & $x$ & & $\mathrm{X}$ & $603-644$ & & & & $x$ \\
\hline Pelagia noctiluca (Forsskål, 1775) & $x$ & $x$ & $x$ & $153-1028$ & 18 & 87 & & \\
\hline Savalia savaglia (Bertoloni, 1819) & & & $\mathrm{X}$ & $625-843$ & & & & $X$ \\
\hline Swiftia pallida cf.Madsen, 1970 & & $x$ & $\mathrm{X}$ & $272-716$ & & & & $x$ \\
\hline Villogorgia bebrycoides (Koch, 1887) & & & $X$ & $128-141$ & & & 10 & \\
\hline Virgularia mirabilis (Müller, 1776) & & & $x$ & 129 & & & 5 & \\
\hline \multicolumn{9}{|l|}{ ANNELIDA } \\
\hline Bonellia viridis Rolando, 1822 & $x$ & $x$ & $X$ & $88-561$ & & & & $x$ \\
\hline Euarche tubifex Ehlers, 1887 & $x$ & $x$ & $\mathrm{X}$ & $105-551$ & 23 & & 6 & \\
\hline Hyalinoecia tubicola (O.F. Müller, 1776) & $x$ & $x$ & $\mathrm{X}$ & $98-405$ & 28 & & 20 & $x$ \\
\hline
\end{tabular}


Table A7. Cont.

\begin{tabular}{|c|c|c|c|c|c|c|c|c|}
\hline & \multicolumn{3}{|c|}{ Area } & \multicolumn{5}{|c|}{ Sampling method } \\
\hline & SO & AM & EB & Depth (m) & BT & GOC & RD & ROV \\
\hline $\begin{array}{c}\text { Laetmonice hystrix (Savigny in } \\
\text { Lamarck, 1818) }\end{array}$ & $X$ & $X$ & $X$ & $105-290$ & 11 & & & \\
\hline Lanice conchilega (Pallas, 1766) & $x$ & $x$ & $x$ & $103-624$ & 15 & & 12 & $x$ \\
\hline Pomatoceros triqueter (Linnaeus, 1758) & $x$ & $x$ & $x$ & $105-445$ & 25 & & & \\
\hline Sabella pavonina Savigny, 1822 & & $X$ & & 88 & & & & $X$ \\
\hline Serpula vermicularis Linnaeus, 1767 & & & $x$ & 146 & 3 & & & \\
\hline Serpulidae * & & $x$ & $x$ & $93-530$ & & & & $x$ \\
\hline $\begin{array}{l}\text { Vermiliopsis infundibulum } \\
\text { (Philippi, 1844) }\end{array}$ & & $x$ & & 90 & & & 7 & \\
\hline \multicolumn{9}{|l|}{ CRUSTACEA } \\
\hline Acanthephyra eximia Smith, 1884 & & & $X$ & 759 & & 7 & & \\
\hline Acanthephyra pelagica (Risso, 1816) & & & $X$ & $732-1028$ & 3 & 40 & & \\
\hline $\begin{array}{l}\text { Achaeus cranchii Leach, } 1817 \text { [in Leach, } \\
\text { 1815-1875] }\end{array}$ & $X$ & $x$ & & $113-242$ & 3 & & 8 & \\
\hline Aegaeon lacazei (Gourret, 1887) & $X$ & $x$ & $X$ & $124-688$ & 21 & 13 & & \\
\hline Alpheus cf. dentipes Guérin, 1832 & $x$ & & & 305 & & 7 & & \\
\hline Alpheus glaber (Olivi, 1792) & $X$ & $\mathrm{X}$ & $X$ & $112-474$ & 23 & & 7 & \\
\hline Alpheus macrocheles (Hailstone, 1835) & & & $x$ & 160 & & & 5 & \\
\hline Alpheus platydactylus Coutière, 1897 & $x$ & $x$ & $x$ & $105-609$ & 9 & 1 & 14 & \\
\hline $\begin{array}{l}\text { Anamathia rissoana (P. Roux, } 1828 \text { [in P. } \\
\text { Roux, 1828-1830]) }\end{array}$ & $\mathrm{X}$ & & & $607-680$ & 12 & & & \\
\hline $\begin{array}{l}\text { Anapagurus laevis (Bell, } 1845 \text { [in Bell, } \\
\text { 1844-1853]) }\end{array}$ & $X$ & $X$ & $X$ & $105-556$ & 49 & & 7 & \\
\hline $\begin{array}{l}\text { Aristaeomorpha foliacea (Risso, } 1827 \text { in } \\
\text { [Risso, 1826-1827]) }\end{array}$ & & & $X$ & 756 & & 7 & & \\
\hline Aristeus antennatus (Risso, 1816) & & $x$ & $x$ & $542-1089$ & 3 & 63 & & $x$ \\
\hline Atelecyclus rotundatus (Olivi, 1792) & & & $X$ & 146 & 3 & & & \\
\hline $\begin{array}{l}\text { Bathynectes maravigna } \\
\text { (Prestandrea, 1839) }\end{array}$ & & & $\mathrm{X}$ & $543-750$ & & & & $x$ \\
\hline Calappa granulata (Linnaeus, 1758) & $x$ & $x$ & $x$ & $105-365$ & 25 & 7 & 9 & $x$ \\
\hline $\begin{array}{l}\text { Calocaris macandreae Bell, } 1846 \text { [in Bell, } \\
\text { 1844-1853] }\end{array}$ & $X$ & $x$ & $X$ & $288-770$ & 31 & 13 & & \\
\hline $\begin{array}{l}\text { Chlorotocus crassicornis (A. } \\
\text { Costa, 1871) }\end{array}$ & $X$ & $x$ & $\mathrm{X}$ & $275-510$ & 20 & 33 & & \\
\hline Crustacea * & & & $x$ & $1068-1086$ & & & & $x$ \\
\hline $\begin{array}{c}\text { Cymonomus granulatus (Norman in C. } \\
\text { W. Thomson, 1873) }\end{array}$ & $\mathrm{X}$ & $X$ & $x$ & $259-483$ & 20 & & & \\
\hline Dardanus arrosor (Herbst, 1796) & $x$ & $x$ & $x$ & $98-328$ & 23 & 13 & 5 & $x$ \\
\hline Dardanus sp. * & & $x$ & & 215 & & & & $x$ \\
\hline $\begin{array}{l}\text { Derilambrus angulifrons } \\
\quad \text { (Latreille, 1825) }\end{array}$ & & $x$ & $X$ & $122-150$ & 7 & & & \\
\hline Distolambrus maltzami (Miers, 1881) & & $x$ & $x$ & $98-412$ & 43 & & & \\
\hline
\end{tabular}


Table A7. Cont.

\begin{tabular}{|c|c|c|c|c|c|c|c|c|}
\hline & \multicolumn{3}{|c|}{ Area } & \multicolumn{5}{|c|}{ Sampling method } \\
\hline & SO & $\mathbf{A M}$ & EB & Depth (m) & BT & GOC & RD & ROV \\
\hline $\begin{array}{l}\text { Dorhynchus thomsoni C. W. } \\
\text { Thomson, } 1873\end{array}$ & $x$ & $x$ & $x$ & $112-688$ & 8 & & & \\
\hline $\begin{array}{l}\text { Ebalia cranchii Leach, } 1817 \text { [in Leach, } \\
\text { 1815-1875] }\end{array}$ & $x$ & & & 290-303 & 4 & & 8 & \\
\hline Ebalia deshayesi H. Lucas, 1846 & $x$ & $x$ & $x$ & $105-548$ & 23 & & & \\
\hline $\begin{array}{l}\text { Ebalia edwardsii O.G. Costa, } 1838 \text { [in } \\
\text { O.G. Costa \& A. Costa, 1838-1871] }\end{array}$ & & $x$ & & 98 & 3 & & & \\
\hline Ebalia nux A. Milne-Edwards, 1883 & $x$ & $x$ & $x$ & $124-680$ & 60 & & 9 & \\
\hline Ebalia tuberosa (Pennant, 1777) & $x$ & $x$ & $x$ & $100-674$ & 26 & & 7 & \\
\hline $\begin{array}{c}\text { Ergasticus clouei A. } \\
\text { Milne-Edwards, } 1882\end{array}$ & $x$ & $x$ & $x$ & $105-757$ & 65 & & 5 & \\
\hline Ethusa mascarone (Herbst, 1785) & & & $x$ & 314 & 3 & & & \\
\hline Eurynome aspera (Pennant, 1777) & & $x$ & $x$ & $98-548$ & 37 & & & \\
\hline Eusergestes arcticus (Krøyer, 1855) & $x$ & $X$ & $x$ & $444-770$ & 14 & 47 & & $X$ \\
\hline Galathea nexa Embleton, 1836 & & $X$ & & $100-631$ & 3 & & 7 & \\
\hline Galathea sp. * & & & $x$ & 636 & & & & $x$ \\
\hline Gennadas elegans (Smith, 1882) & $x$ & $x$ & $x$ & $147-1028$ & 11 & 40 & & \\
\hline $\begin{array}{c}\text { Geryon longipes A. Milne-Edwards, } \\
1882\end{array}$ & $x$ & $x$ & $x$ & $460-770$ & 19 & 77 & 8 & $x$ \\
\hline Goneplax rhomboides (Linnaeus, 1758) & $x$ & $x$ & $x$ & $290-510$ & 8 & 20 & & \\
\hline Homola barbata (Fabricius, 1793) & & & $x$ & 511 & 3 & & & \\
\hline Idotea metallica Bosc, 1802 & & $X$ & & 122 & 3 & & & \\
\hline Inachus dorsettensis (Pennant, 1777) & $x$ & $x$ & $x$ & $98-729$ & 42 & 7 & 7 & \\
\hline $\begin{array}{l}\text { Inachus leptochirus Leach, } 1817 \text { [in } \\
\text { Leach, 1815-1875] }\end{array}$ & $x$ & $x$ & $x$ & $99-328$ & 15 & 7 & & \\
\hline Inachus sp. * & & $x$ & & 85 & & & & $x$ \\
\hline $\begin{array}{l}\text { Latreillia elegans P. Roux, } 1830 \text { [in P. } \\
\text { Roux, 1828-1830] }\end{array}$ & $x$ & $x$ & $x$ & $124-680$ & 3 & & & \\
\hline Ligur ensiferus (Risso, 1816) & & $x$ & & $459-510$ & & 20 & & \\
\hline Liocarcinus depurator (Linnaeus, 1758) & $x$ & $x$ & $x$ & $105-365$ & 11 & & & \\
\hline Liocarcinus zariquieyi (Gordon, 1968) & & $x$ & & $105-135$ & 14 & & & \\
\hline Lophogaster typicus M. Sars, 1857 & $x$ & $x$ & $x$ & $105-757$ & 66 & 20 & 8 & \\
\hline $\begin{array}{l}\text { Macropipus tuberculatus (P. Roux, } 1830 \\
\text { [in P. Roux, 1828-1830]) }\end{array}$ & $x$ & $x$ & $x$ & $105-548$ & 20 & 7 & & $x$ \\
\hline $\begin{array}{l}\text { Macropodia linaresi Forest \& Zariquiey } \\
\text { Álvarez, } 1964\end{array}$ & & $x$ & & 127 & 3 & & & \\
\hline $\begin{array}{c}\text { Macropodia longipes (A. } \\
\text { Milne-Edwards \& Bouvier, 1899) }\end{array}$ & & $x$ & & 135 & 3 & & & \\
\hline $\begin{array}{c}\text { Meganyctiphanes norvegica (M. } \\
\text { Sars, 1857) }\end{array}$ & $X$ & & & $275-290$ & 8 & & & \\
\hline Monodaeus couchii (RQ Couch, 1851) & $x$ & $x$ & $x$ & $98-760$ & 53 & 17 & 15 & \\
\hline
\end{tabular}


Table A7. Cont.

\begin{tabular}{|c|c|c|c|c|c|c|c|c|}
\hline & \multicolumn{3}{|c|}{ Area } & \multirow[b]{2}{*}{ Depth (m) } & \multicolumn{4}{|c|}{ Sampling method } \\
\hline & SO & AM & EB & & BT & GOC & RD & ROV \\
\hline $\begin{array}{l}\text { Munida intermedia A. Milne-Edwards } \\
\text { \& Bouvier, } 1899\end{array}$ & & $x$ & $x$ & $348-574$ & 7 & 27 & & $x$ \\
\hline $\begin{array}{c}\text { Munida perarmata A. Milne Edwards } \\
\text { \& Bouvier, } 1894\end{array}$ & $x$ & $x$ & $x$ & $277-768$ & 14 & 53 & & \\
\hline Munida speciosa von Martens, 1878 & $x$ & $x$ & $x$ & $99-697$ & 27 & & & \\
\hline Munida spp. * & $X$ & $X$ & $X$ & $107-1068$ & & & & $x$ \\
\hline Natantia * & $x$ & & $x$ & $298-843$ & & & & $\mathrm{x}$ \\
\hline Natatolana borealis (Lilljeborg, 1851) & & $x$ & $x$ & $116-412$ & 13 & & & \\
\hline Nephrops norvegicus (Linnaeus, 1758) & $x$ & $x$ & $x$ & $328-627$ & 7 & 60 & & $x$ \\
\hline Paguroidea * & $x$ & $x$ & $X$ & $140-283$ & & & & $x$ \\
\hline Paguristes eremita (Linnaeus, 1767) & & & $x$ & 127 & 3 & & & \\
\hline Pagurus alatus J.C. Fabricius, 1775 & $x$ & $x$ & $x$ & $352-680$ & 16 & 7 & & $x$ \\
\hline $\begin{array}{c}\text { Pagurus anachoretus Risso, } 1827 \text { in } \\
\text { [Risso, 1826-1827] }\end{array}$ & $x$ & $X$ & $X$ & $116-275$ & BT & 6 & & \\
\hline $\begin{array}{l}\text { Pagurus prideaux } \text { Leach, } 1815 \text { [in } \\
\text { Leach, 1815-1875] }\end{array}$ & & $x$ & $x$ & 98-277 & 30 & & 5 & \\
\hline $\begin{array}{l}\text { Palicus caronii (P. Roux, } 1830 \text { [in P. } \\
\text { Roux, 1828-1830]) }\end{array}$ & & $X$ & $X$ & $122-147$ & 3 & & & \\
\hline Palinurus elephas (JC. Fabricius, 1787) & & & $X$ & 107 & & & & $x$ \\
\hline Palinurus mauritanicus Gruvel, 1911 & $X$ & $x$ & & $285-386$ & & & & $x$ \\
\hline $\begin{array}{c}\text { Parapenaeus longirostris }(\mathrm{H} . \\
\text { Lucas, } 1846)\end{array}$ & $x$ & $x$ & $x$ & $267-542$ & 18 & 47 & 7 & $x$ \\
\hline Paromola cuvieri (Risso, 1816) & $x$ & $X$ & $x$ & $444-759$ & & 37 & & $x$ \\
\hline $\begin{array}{l}\text { Parthenopoides massena (P. Roux, } 1830 \\
\text { [in P. Roux, 1828-1830]) }\end{array}$ & & $X$ & $X$ & $105-153$ & 28 & & & \\
\hline Pasiphaea multidentata Esmark, 1866 & $x$ & $x$ & $X$ & $147-768$ & 7 & 70 & & \\
\hline Pasiphaea sivado (Risso, 1816) & & $X$ & $X$ & $444-732$ & 3 & 13 & & \\
\hline $\begin{array}{l}\text { Philocheras bispinosus } \\
\text { (Hailstone, 1835) }\end{array}$ & $X$ & & & 680 & 4 & & & \\
\hline Philocheras echinulatus (M. Sars, 1862) & $X$ & $X$ & $X$ & $290-688$ & 16 & 7 & & \\
\hline Phronima sedentaria (Forskål, 1775) & $X$ & $X$ & $x$ & $135-1028$ & 13 & 50 & & \\
\hline Phrosina semilunata Risso, 1822 & & & $X$ & $768-1028$ & & 13 & & \\
\hline Plesionika acanthonotus (Smith, 1882) & $X$ & $x$ & $x$ & $150-768$ & 19 & 67 & & $x$ \\
\hline $\begin{array}{c}\text { Plesionika antigai Zariquiey } \\
\text { Álvarez, } 1955\end{array}$ & $X$ & $X$ & $X$ & $147-511$ & 34 & 13 & 9 & $X$ \\
\hline $\begin{array}{c}\text { Plesionika edwardsii (J.F. Brandt in von } \\
\text { Middendorf, 1851) }\end{array}$ & $x$ & $x$ & $x$ & $249-510$ & 4 & 13 & 8 & $x$ \\
\hline Plesionika gigliolii (Senna, 1902) & $X$ & $X$ & $X$ & $148-631$ & 15 & 53 & 22 & $x$ \\
\hline Plesionika heterocarpus (A. Costa, 1871) & $X$ & $X$ & $X$ & $237-619$ & 14 & 47 & & \\
\hline $\begin{array}{l}\text { Plesionika martia (A. } \\
\text { Milne-Edwards, 1883) }\end{array}$ & $X$ & $X$ & $X$ & $393-768$ & 20 & 87 & & $X$ \\
\hline Plesionika narval (J.C. Fabricius, 1787) & $X$ & $x$ & $x$ & $241-459$ & 9 & 7 & 25 & \\
\hline
\end{tabular}


Table A7. Cont.

\begin{tabular}{|c|c|c|c|c|c|c|c|c|}
\hline & \multicolumn{3}{|c|}{ Area } & \multicolumn{5}{|c|}{ Sampling method } \\
\hline & SO & AM & EB & Depth (m) & BT & GOC & RD & ROV \\
\hline Plesionika spp. * & $X$ & $X$ & $x$ & 200-1072 & & & & $X$ \\
\hline Polycheles typhlops Heller, 1862 & $X$ & $X$ & $X$ & $459-768$ & 21 & 73 & & \\
\hline Pontophilus norvegicus (M. Sars, 1861) & & & $x$ & $729-768$ & & 27 & & \\
\hline Pontophilus spinosus (Leach, 1816) & & $x$ & & 445 & 3 & & & \\
\hline $\begin{array}{l}\text { Processa canaliculata Leach, } 1815 \text { [in } \\
\text { Leach, 1815-1875] }\end{array}$ & $x$ & $x$ & $x$ & $114-548$ & 25 & 27 & & \\
\hline $\begin{array}{c}\text { Processa macrophthalma Nouvel \& } \\
\text { Holthuis, } 1957\end{array}$ & & & $x$ & 146 & 6 & & & \\
\hline $\begin{array}{c}\text { Processa nouveli Al-Adhub \& } \\
\text { Williamson, } 1975\end{array}$ & $x$ & $x$ & $\mathrm{X}$ & $127-510$ & 15 & 13 & & \\
\hline Reptantia * & & & $x$ & 340 & & & & $x$ \\
\hline Rissoides desmaresti (Risso, 1816) & & $x$ & & $444-510$ & 3 & 13 & & \\
\hline Robustosergia robusta (Smith, 1882) & $x$ & $x$ & $x$ & $542-1028$ & 11 & 70 & & \\
\hline Rocinella dumerilii (Lucas, 1849) & & $x$ & $x$ & $147-674$ & 8 & & & \\
\hline Scalpellum (Linnaeus, 1767) & & $x$ & & 99 & 3 & & & \\
\hline $\begin{array}{c}\text { Scyllarus pygmaeus (Spence Bate, } \\
\text { 1888) }\end{array}$ & & $x$ & & 90 & & & 7 & \\
\hline Solenocera membranacea (Risso, 1816) & $x$ & $x$ & $x$ & $122-511$ & 20 & 257 & & \\
\hline $\begin{array}{l}\text { Spinolambrus macrochelos (Herbst, } \\
1790 \text { [in Herbst, 1782-1790]) }\end{array}$ & & $x$ & $x$ & $127-137$ & 5 & & & \\
\hline Thia scutellata (Fabricius, 1793) & & $x$ & & 122 & 3 & & & \\
\hline \multicolumn{9}{|l|}{ MOLLUSCA } \\
\hline Abra longicallus (Scacchi, 1835) & $x$ & $X$ & $x$ & $195-740$ & 23 & & & \\
\hline Abralia veranyi (Rüppell, 1844) & & $x$ & & $393-460$ & & 27 & & \\
\hline Addisonia excentrica (Tiberi, 1855) & & $x$ & & 116 & 3 & & & \\
\hline $\begin{array}{l}\text { Aequipecten commutatus } \\
\text { (Monterosato, 1875) }\end{array}$ & & & $x$ & 412 & 3 & & & \\
\hline Alloteuthis media (Linnaeus, 1758) & & $x$ & & 619 & & 7 & & \\
\hline $\begin{array}{l}\text { Anadara carbuloides } \\
\text { (Monterosato, 1881) }\end{array}$ & & $x$ & & $112-113$ & 7 & & & \\
\hline $\begin{array}{l}\text { Ancistrocheirus lesueurii (d'Orbigny } \\
\text { [in Férussac \& d'Orbigny], 1842) }\end{array}$ & & $x$ & & 600 & & 7 & & \\
\hline $\begin{array}{l}\text { Ancistroteuthis lischtensteinii (Férussac } \\
\text { [in Férussac \& d'Orbigny], 1835) }\end{array}$ & & $X$ & $X$ & $627-747$ & & 10 & & \\
\hline Anomia ephippium Linnaeus, 1758 & & & $x$ & 274 & & & 5 & \\
\hline Anomiidae & & $x$ & & $105-122$ & 11 & & & \\
\hline Aporrhais serresiana (Michaud, 1828) & $X$ & $x$ & $x$ & $319-640$ & 12 & 7 & & \\
\hline Aptyxis syracusana (Linnaeus, 1758) & & $X$ & & 116 & 3 & & & \\
\hline Arcopella balaustina (Linnaeus, 1758) & & $x$ & & 195 & 3 & & & \\
\hline Arcidae & $x$ & $X$ & $X$ & $100-577$ & 7 & & 33 & \\
\hline Atrina pectinata (Linnaeus, 1767) & & $x$ & & 107 & & & & $X$ \\
\hline Baptodoris cinnabarina Bergh, 1884 & $X$ & $x$ & $x$ & $122-688$ & 12 & & & \\
\hline
\end{tabular}


Table A7. Cont.

\begin{tabular}{|c|c|c|c|c|c|c|c|c|}
\hline & \multicolumn{3}{|c|}{ Area } & & \multicolumn{4}{|c|}{ Sampling method } \\
\hline & SO & AM & EB & Depth (m) & BT & GOC & RD & ROV \\
\hline $\begin{array}{c}\text { Bathypolypus sponsalis (P. Fischer \& H. } \\
\text { Fischer, 1892) }\end{array}$ & & $x$ & $x$ & $444-770$ & 3 & 20 & & \\
\hline Bivalvia * & & & $x$ & 802 & & & & $x$ \\
\hline Calliostoma conulum (Linnaeus, 1758) & & & $x$ & 288 & 3 & & & \\
\hline Calliostoma granulatum (Born, 1778) & $x$ & $x$ & $x$ & $105-412$ & 28 & & 8 & \\
\hline Calliostoma gubbioli Nofroni, 1984 & $x$ & $x$ & & $275-397$ & 4 & & 7 & \\
\hline $\begin{array}{l}\text { Calliostoma zizyphinum } \\
\text { (Linnaeus, 1758) }\end{array}$ & & $x$ & $x$ & $225-483$ & 7 & & & \\
\hline Callumbonela suturale (Philippi, 1836) & & $x$ & $x$ & $153-365$ & 5 & & & \\
\hline Capulus ungaricus (Linnaeus, 1758) & & $x$ & $X$ & $127-147$ & 3 & & & \\
\hline Cardiomya costellata (Deshayes, 1835) & $x$ & $x$ & & $113-607$ & 13 & & & \\
\hline Cephalopoda * & & $x$ & $x$ & $380-402$ & & & & $x$ \\
\hline Cetomya neaeroides (Seguenza, 1877) & $x$ & & & $298-449$ & 1 & & 1 & \\
\hline Clavatulidae & & $x$ & & $116-365$ & 10 & & & \\
\hline Clelandella miliaris (Brocchi, 1814) & $x$ & $x$ & & $135-474$ & 4 & & & \\
\hline Colidae & & & $x$ & 574 & 1 & & & \\
\hline Comarmondia gracilis (Montagu, 1803) & & & $X$ & 127 & 3 & & & \\
\hline Cuspidaria cuspidata (Olivi, 1792) & $x$ & $X$ & $x$ & $127-474$ & 12 & & & \\
\hline Cuspidaria rostrata (Spengler, 1793) & $x$ & $x$ & $x$ & $114-759$ & 40 & & & \\
\hline Cymbulia peronii Blainville, 1818 & $X$ & $x$ & $x$ & $113-768$ & 11 & 23 & & \\
\hline Danilia tinei (Calcara, 1839) & & $x$ & & 127 & 3 & & & \\
\hline Delectopecten vitreus (Gmelin, 1791) & $\mathrm{X}$ & & $x$ & $640-674$ & 4 & & & \\
\hline Eledone cirrhosa (Lamarck, 1798) & & $x$ & & $122-446$ & 7 & 7 & & $x$ \\
\hline Eledone sp. * & & $X$ & & $260-342$ & & & & $x$ \\
\hline Emarginula adriatica O.G. Costa, 1830 & & & $X$ & $128-141$ & & & 10 & \\
\hline Epitonium celesti (Aradas, 1854) & & & $x$ & $150-412$ & 6 & & & \\
\hline Euspira fusca (Blainville, 1825) & $x$ & $x$ & $x$ & $242-474$ & 12 & & 8 & \\
\hline Fusinus pulchellus (Philippi, 1840) & & $X$ & $X$ & 105-395 & 12 & & & \\
\hline $\begin{array}{l}\text { Gastropteron rubrum } \\
\text { (Rafinesque, 1814) }\end{array}$ & & $x$ & & $105-242$ & 7 & & & \\
\hline Gracilipurpura rostrata (Olivi, 1792) & & $x$ & $x$ & $127-483$ & 10 & & & \\
\hline Heteroteuthis dispar (Rüppell, 1844) & & & $X$ & 732 & & 7 & & \\
\hline Histioteuthis bonnellii (Férussac, 1834) & & $X$ & & $444-663$ & & 47 & & \\
\hline Histioteuthis reversa (Verrill, 1880) & & $X$ & $x$ & $600-757$ & & 33 & & \\
\hline Illex coindetii (Vérany, 1839) & & $x$ & & $237-542$ & & 33 & & \\
\hline Japonactaeon pusillus (Forbes, 1844) & $x$ & & & 556 & 4 & & & \\
\hline $\begin{array}{l}\text { Kaloplocamus ramosus } \\
\text { (Cantraine, 1835) }\end{array}$ & & & $x$ & 141 & & & 5 & \\
\hline Karnekampia sulcata (O.F. Müller, 1776) & & $X$ & $X$ & $127-348$ & 5 & & & \\
\hline Lima (Linnaeus, 1758) & & $x$ & & 105 & 3 & & & \\
\hline
\end{tabular}


Table A7. Cont.

\begin{tabular}{|c|c|c|c|c|c|c|c|c|}
\hline & \multicolumn{3}{|c|}{ Area } & \multicolumn{5}{|c|}{ Sampling method } \\
\hline & SO & AM & EB & Depth (m) & BT & GOC & RD & ROV \\
\hline Lima sp. * & & & $x$ & 1068 & & & & $x$ \\
\hline Limaria tuberculata (Olivi, 1792) & & $x$ & & 267 & & & 7 & \\
\hline Loligo forbesii Steenstrup, 1856 & & $x$ & & $328-460$ & & 20 & & \\
\hline Lyonsiidae & $x$ & & & $609-697$ & 8 & & & \\
\hline Manupecten pesfelis (Linnaeus, 1758) & & $x$ & $x$ & $122-127$ & 3 & & & \\
\hline Mimachlamys varia (Linnaeus, 1758 ) & $X$ & & & 290 & & & 8 & \\
\hline Mitrella gervillii (Payraudeau, 1826) & & & $x$ & 577 & & & 5 & \\
\hline Neorossia caroli (Joubin, 1902) & & $x$ & & $444-459$ & & 13 & & \\
\hline Neopycnodonte sp. Stenzel, 1971 & $X$ & $x$ & $x$ & $299-412$ & & & & $X$ \\
\hline Nucula nitidiosa Winckworth, 1930 & & $x$ & & $320-365$ & 7 & & & \\
\hline Ocenebra erinaceus (Linnaeus, 1758) & & $x$ & & 225 & 3 & & & \\
\hline Octopus salutii Vérany, 1839 & & $x$ & & $328-601$ & & 20 & & \\
\hline Octopus vulgaris Cuvier, 1797 & & & $x$ & 169 & & & & $x$ \\
\hline Octopodoidea * & & & $x$ & 324 & & & & $x$ \\
\hline $\begin{array}{l}\text { Onchidella celtica (Audouin \& } \\
\text { Milne-Edwards, 1832) }\end{array}$ & $x$ & & & 242 & & & 8 & \\
\hline Orania fusulus (Brocchi, 1814) & & & $x$ & 129 & & & 5 & \\
\hline Pagodula echinata (Kiener, 1839) & $x$ & $x$ & $x$ & $267-680$ & 11 & & 7 & \\
\hline Palliolum incomparabile (Risso, 1826) & & $x$ & $x$ & $127-508$ & 3 & & & \\
\hline Palliolum tigerinum (O.F. Müller, 1776) & & $x$ & & 116 & 3 & & & \\
\hline $\begin{array}{l}\text { Parvamussium fenestratum } \\
\text { (Forbes, 1844) }\end{array}$ & & $x$ & $x$ & $127-511$ & 8 & & & \\
\hline Peltodoris sp. & & & $X$ & 133 & & & & $X$ \\
\hline Philine monterosati Monterosato, 1874 & $x$ & $x$ & $x$ & $98-740$ & 21 & & & \\
\hline $\begin{array}{l}\text { Pleurobranchaea meckeli } \\
\text { (Blainville, 1825) }\end{array}$ & & $x$ & & 114 & 3 & & & \\
\hline Policordia gemma (A. E. Verrill, 1880) & & & $X$ & 577 & & & 5 & \\
\hline $\begin{array}{c}\text { Poromya granulata (Nyst \& } \\
\text { Westendorp, 1839) }\end{array}$ & & $X$ & & $122-352$ & 21 & & & \\
\hline Pseudamussium clavatum (Poli, 1795) & & $x$ & $x$ & $105-352$ & 27 & & & \\
\hline Ranella olearium (Linnaeus, 1758) & & & $x$ & $137-412$ & 35 & & & \\
\hline Raphitomidae & $x$ & $x$ & $x$ & $225-574$ & 7 & & & \\
\hline Rhinoclama nitens (Locard, 1898) & $x$ & & & $482-523$ & 8 & & & \\
\hline Rondeletiola minor (Naef, 1912) & & $x$ & & 320 & 3 & & & \\
\hline Rossia macrosoma (Delle Chiaje, 1830) & & $x$ & $x$ & $328-548$ & 3 & 12 & & \\
\hline $\begin{array}{l}\text { Scaeurgus unicirrhus (Delle Chiaje [in } \\
\text { Férussac \& d'Orbigny], 1841) }\end{array}$ & & $x$ & $x$ & $105-143$ & 3 & & & \\
\hline Scaphander lignarius (Linnaeus, 1758) & $x$ & $x$ & $X$ & $122-445$ & 7 & & & \\
\hline Sepia elegans Blainville, 1827 & & $x$ & $x$ & $105-299$ & 15 & & & $x$ \\
\hline $\begin{array}{c}\text { Sepia orbignyana Férussac [in } \\
\text { d'Orbigny], } 1826 \\
\end{array}$ & & $x$ & $x$ & $146-237$ & 3 & 7 & & \\
\hline Sepietta oweniana (d'Orbigny, 1841) & $x$ & $x$ & $x$ & $112-542$ & 29 & 47 & & \\
\hline
\end{tabular}


Table A7. Cont.

\begin{tabular}{|c|c|c|c|c|c|c|c|c|}
\hline & \multicolumn{3}{|c|}{ Area } & \multicolumn{5}{|c|}{ Sampling method } \\
\hline & SO & AM & EB & Depth (m) & BT & GOC & RD & ROV \\
\hline Sepiolidae * & $x$ & & $x$ & $340-620$ & & & & $x$ \\
\hline Similipecten similis (Laskey, 1811) & $x$ & $x$ & & $105-298$ & 11 & & & \\
\hline Spisula subtruncata (da Costa, 1778) & $x$ & & & 259 & 4 & & & \\
\hline Spondylidae & & & $x$ & 137 & & & 5 & \\
\hline Stoloteuthis leucoptera (Verrill, 1878) & & $X$ & & 459 & & 7 & & \\
\hline Taonius pavo (Lesueur, 1821) & & & $x$ & 1028 & & 7 & & \\
\hline Tectonatica rizzae (Philippi, 1844) & $x$ & $x$ & & $105-445$ & 7 & & & \\
\hline Todarodes sagittatus (Lamarck, 1798) & & $x$ & $x$ & $328-770$ & & 47 & & \\
\hline Todaropsis eblanae (Ball, 1841) & & $x$ & & 460 & & 7 & & \\
\hline $\begin{array}{c}\text { Trophonopsis barvicensis (G. } \\
\text { Johnston, 1825) }\end{array}$ & $x$ & & & 259 & 4 & & & \\
\hline Trophonopsis muricata (Montagu, 1803) & & $x$ & & 319 & 3 & & & \\
\hline Tropidomya abbreviata (Forbes, 1843) & & $x$ & $x$ & $122-402$ & 13 & & & \\
\hline Turbinidae & & & $x$ & 508 & 3 & & & \\
\hline Xenophora crispa (König, 1825) & & $x$ & $X$ & $122-297$ & 5 & & & \\
\hline \multicolumn{9}{|l|}{ ECHINODERMATA } \\
\hline $\begin{array}{c}\text { Amphipholis squamata (Delle } \\
\text { Chiaje, 1828) }\end{array}$ & $x$ & & & 680 & 4 & & & \\
\hline Amphiura chiajei Forbes, 1843 & $X$ & $X$ & $\mathrm{X}$ & $114-445$ & 11 & & 7 & \\
\hline Amphiura filiformis (O.F. Müller, 1776) & $x$ & $x$ & $x$ & $146-508$ & 25 & & 6 & \\
\hline Anseropoda placenta (Pennant, 1777) & & $x$ & $x$ & 98-195 & 32 & & 7 & \\
\hline Antedon mediterranea (Lamarck, 1816) & & $x$ & $x$ & $127-153$ & 7 & & & \\
\hline Asteroidea sp. 1 & & $x$ & $x$ & $105-153$ & 15 & & & \\
\hline Asteroidea sp. 2 & & & $x$ & $412-770$ & 13 & 7 & & \\
\hline Asteroidea sp. 3 & & $x$ & $x$ & $114-147$ & 7 & & & \\
\hline Asteroidea * & & & $x$ & 150 & & & & $x$ \\
\hline Astropecten irregularis (Pennant, 1777) & & $x$ & $x$ & $113-445$ & 17 & 13 & & \\
\hline Astropecten sp. * & & $x$ & & $242-342$ & & & & $x$ \\
\hline $\begin{array}{c}\text { Brissopsis atlantica mediterranea } \\
\text { Mortensen, } 1913\end{array}$ & $x$ & $x$ & & $500-609$ & 4 & & & \\
\hline Ceramaster grenadensis (Perrier, 1881) & & & $x$ & 760 & & 7 & & \\
\hline Chaetaster longipes (Bruzelius, 1805) & & $x$ & $x$ & $91-548$ & 27 & & 9 & $x$ \\
\hline Cidaris cidaris (Linnaeus, 1758) & $x$ & $x$ & $x$ & $105-574$ & 35 & 7 & 5 & $x$ \\
\hline Crinoidea * & $x$ & & $x$ & $380-500$ & & & & $x$ \\
\hline Echinaster sepositus (Retzius, 1783) & & $x$ & & $85-105$ & & & & $x$ \\
\hline $\begin{array}{l}\text { Echinocyamus pusillus (O.F. } \\
\text { Müller, 1776) }\end{array}$ & $x$ & $x$ & $x$ & $127-275$ & 7 & & & \\
\hline Echinodea * & $x$ & $x$ & $x$ & $188-610$ & & & & $x$ \\
\hline Echinus melo Lamarck, 1816 & $x$ & & $x$ & $147-278$ & 4 & & & $x$ \\
\hline Gracilechinus acutus (Lamarck, 1816) & $x$ & $x$ & $x$ & $112-680$ & 22 & 20 & & $x$ \\
\hline Hacelia attenuata Gray, 1840 & & $x$ & & $90-121$ & 17 & & 21 & $x$ \\
\hline
\end{tabular}


Table A7. Cont.

\begin{tabular}{|c|c|c|c|c|c|c|c|c|}
\hline & \multicolumn{3}{|c|}{ Area } & \multicolumn{5}{|c|}{ Sampling method } \\
\hline & SO & AM & EB & Depth (m) & BT & GOC & RD & ROV \\
\hline Holothuria forskali Delle Chiaje, 1824 & & $x$ & & 99 & 3 & & & $x$ \\
\hline Holothuria tubulosa Gmelin, 1791 & & $x$ & $x$ & $105-127$ & 3 & & 5 & $x$ \\
\hline Holothuria sp. ${ }^{*}$ & & $x$ & & 85 & & & & $x$ \\
\hline Holothuroidea * & & & $x$ & $169-724$ & & & & $x$ \\
\hline $\begin{array}{c}\text { Leptometra celtica (M'Andrew \& } \\
\text { Barrett, 1857) }\end{array}$ & $x$ & $x$ & $x$ & $114-680$ & 12 & & & $x$ \\
\hline Luidia ciliaris (Philippi, 1837) & & $x$ & $x$ & $105-242$ & 10 & & 5 & \\
\hline $\begin{array}{c}\text { Luidia sarsii Düben \& Koren in } \\
\text { Düben, } 1844\end{array}$ & $x$ & $x$ & $X$ & $98-548$ & 39 & & & \\
\hline Marthasterias glacialis (Linnaeus, 1758) & $x$ & $x$ & $x$ & 98-395 & 25 & & 8 & \\
\hline $\begin{array}{c}\text { Mesothuria intestinalis } \\
\text { (Ascanius, 1805) }\end{array}$ & & $x$ & $x$ & $225-759$ & 8 & 7 & & $x$ \\
\hline Oestergrenia digitata (Montagu, 1815) & $x$ & $x$ & & $242-472$ & 9 & & & \\
\hline Ophiacantha setosa (Bruzelius, 1805) & & & $x$ & 141 & & & 5 & \\
\hline Ophiactis balli (W. Thompson, 1840) & $X$ & & $x$ & $160-298$ & & & 6 & \\
\hline Ophiocten abyssicolum (Forbes, 1843) & $x$ & $x$ & $x$ & $98-548$ & 26 & & & \\
\hline Ophiomyces grandis Lyman, 1879 & $x$ & $x$ & $x$ & $122-548$ & 36 & & 7 & \\
\hline Ophiopsila annulosa (M. Sars, 1859) & & $X$ & $x$ & $116-153$ & 13 & & & \\
\hline Ophiopsila aranea Forbes, 1843 & & $X$ & $X$ & $105-319$ & 20 & & & \\
\hline $\begin{array}{l}\text { Ophiothrix fragilis (Abildgaard in O.F. } \\
\text { Müller, 1789) }\end{array}$ & $X$ & $X$ & & $114-259$ & 7 & & & \\
\hline $\begin{array}{l}\text { Ophiothrix quinquemaculata (Delle } \\
\text { Chiaje, 1828) }\end{array}$ & $x$ & & & 278 & 4 & & & \\
\hline $\begin{array}{c}\text { Ophiura (Dictenophiura) carnea } \\
\text { Lütken, } 1858\end{array}$ & $x$ & $x$ & $x$ & $105-511$ & 43 & & 15 & \\
\hline Ophiura albida Forbes, 1839 & $x$ & & & 298 & 4 & & & \\
\hline Ophiura grubei Heller, 1863 & & $x$ & $x$ & $105-288$ & 13 & & & \\
\hline Ophiuroieda sp. 1 & $x$ & $x$ & & $410-556$ & 6 & & & \\
\hline Ophiuroieda sp. 2 & & & $X$ & 141 & & & 5 & \\
\hline Ophiuroieda sp. 3 & & & $x$ & 150 & 3 & & & \\
\hline Ophiuroieda sp. 4 & $x$ & & & 303-305 & & & 17 & \\
\hline Parastichopus regalis (Cuvier, 1817) & & $x$ & $x$ & $114-288$ & 18 & 13 & & $x$ \\
\hline $\begin{array}{c}\text { Peltaster placenta (Müller \& } \\
\text { Troschel, 1842) }\end{array}$ & $x$ & $x$ & $x$ & $105-412$ & 37 & & 11 & $x$ \\
\hline $\begin{array}{c}\text { Psammechinus microtuberculatus } \\
\text { (Blainville, 1825) }\end{array}$ & $x$ & & $x$ & $146-290$ & 7 & & & \\
\hline $\begin{array}{c}\text { Pseudostichopus occultatus Marenzeller } \\
\text { von, } 1893\end{array}$ & $x$ & $x$ & $x$ & $124-511$ & 20 & & 7 & \\
\hline $\begin{array}{l}\text { Sclerasterias richardi (Perrier in } \\
\text { Milne-Edwards, 1882) }\end{array}$ & $x$ & $x$ & $x$ & $105-548$ & 38 & & 10 & $x$ \\
\hline Spatangus purpureus O.F. Müller, 1776 & $x$ & $X$ & $x$ & $137-412$ & 15 & 7 & & $X$ \\
\hline Stichopodidae & $x$ & & & $278-697$ & 8 & & & $x$ \\
\hline Tethyaster subinermis (Philippi, 1837) & & $x$ & & $195-328$ & 3 & 7 & & \\
\hline
\end{tabular}


Table A7. Cont.

\begin{tabular}{|c|c|c|c|c|c|c|c|c|}
\hline & \multicolumn{3}{|c|}{ Area } & \multicolumn{5}{|c|}{ Sampling method } \\
\hline & SO & AM & EB & Depth (m) & BT & GOC & RD & ROV \\
\hline \multicolumn{9}{|l|}{ BRACHIOPODA } \\
\hline Argyrotheca chordata (Risso, 1826) & & $x$ & $x$ & $90-473$ & 28 & & 56 & \\
\hline Brachiopoda * & $x$ & $x$ & $x$ & 99-432 & & & & $x$ \\
\hline Gryphus vitreus (Born, 1778) & $X$ & $x$ & $x$ & $116-764$ & 59 & 20 & & $x$ \\
\hline Joania cordata (Risso, 1826) & $x$ & $x$ & $x$ & $127-290$ & 5 & & & \\
\hline Mergelia truncata (Linnaeus, 1767) & $x$ & $x$ & $x$ & $90-511$ & 22 & & 50 & \\
\hline \multicolumn{9}{|l|}{ BRYOZOA } \\
\hline $\begin{array}{l}\text { Amphiblestrum lirulatum } \\
\text { (Calvet, 1907) }\end{array}$ & & $x$ & & 402 & 3 & & & \\
\hline Bryozoa * & & & $x$ & $260-295$ & & & & $x$ \\
\hline Hornera sp. & & & $x$ & 133 & & & & $x$ \\
\hline Kinetoskias sp. & $x$ & & & $591-622$ & & & & $x$ \\
\hline Smittina cervicornis (Pallas, 1766) & & $x$ & & 105 & & & 5 & $x$ \\
\hline \multicolumn{9}{|l|}{ THALIACEA } \\
\hline Pyrosoma atlanticum Péron, 1804 & $x$ & $X$ & $X$ & $137-1028$ & 4 & 30 & & \\
\hline Salpa spp. & & $x$ & $x$ & $393-757$ & & 57 & & \\
\hline Salpa maxima Forskål, 1775 & & $x$ & $x$ & $105-1028$ & 10 & 13 & & $x$ \\
\hline Thaliacea * & $x$ & & $x$ & $131-599$ & & & & $x$ \\
\hline \multicolumn{9}{|l|}{ ASCIDIACEA } \\
\hline Ascidia involuta Heller, 1875 & & $x$ & & 108 & & & 7 & \\
\hline Ascidia mentula Müller, 1776 & & & $x$ & 117 & & & 5 & $x$ \\
\hline Ascidiacea sp. 1 * & $x$ & $x$ & $x$ & $100-633$ & & & & $x$ \\
\hline Ascidiacea sp. $2 *$ & & & $X$ & $143-150$ & & & & $X$ \\
\hline Ascidiacea sp. $3 *$ & & $x$ & $x$ & 107-139 & & & & $x$ \\
\hline Ascidiacea sp. $4^{*}$ & & $x$ & & 104 & & & & $x$ \\
\hline Ascidiacea sp. $5^{*}$ & & $x$ & & $88-89$ & & & & $x$ \\
\hline Ascidiacea sp. $6 *$ & & $x$ & & 86 & & & & $X$ \\
\hline Ascidiacea sp. 7 * & $x$ & & & $301-304$ & & & & $x$ \\
\hline Ascidiacea sp. $8^{*}$ & $X$ & & & 314 & & & & $x$ \\
\hline Ascidiacea sp. $9 *$ & & $x$ & $x$ & $134-144$ & & & & $x$ \\
\hline Clavelina dellavallei & $x$ & $x$ & $x$ & $88-349$ & & & & $x$ \\
\hline Diazona violacea Savigny, 1816 & & $x$ & & 90 & & & 7 & $x$ \\
\hline Halocynthia papillosa & & $x$ & & $87-104$ & & & & $x$ \\
\hline \multicolumn{9}{|l|}{ ELASMOBRANCHII } \\
\hline Centrophorus uyato (Rafinesque, 1810) & & & $x$ & $738-760$ & & 27 & & \\
\hline Dalatias licha (Bonnaterre, 1788) & & $x$ & & 542 & & 7 & & \\
\hline Dipturus oxyrinchus (Linnaeus, 1758) & & $x$ & $x$ & $328-757$ & & 10 & & \\
\hline Etmopterus spinax (Linnaeus, 1758) & & $x$ & $x$ & $444-757$ & & 50 & & \\
\hline Galeus melastomus Rafinesque, 1810 & $x$ & $x$ & $x$ & $328-760$ & 4 & 83 & & $x$ \\
\hline $\begin{array}{c}\text { Leucoraja naevus (Müller \& } \\
\text { Henle, 1841) }\end{array}$ & & $x$ & & 237 & & 7 & & \\
\hline
\end{tabular}


Table A7. Cont.

\begin{tabular}{|c|c|c|c|c|c|c|c|c|}
\hline & \multicolumn{3}{|c|}{ Area } & \multicolumn{5}{|c|}{ Sampling method } \\
\hline & SO & AM & EB & Depth (m) & BT & GOC & RD & ROV \\
\hline Raja clavata Linnaeus, 1758 & & $x$ & $x$ & $103-451$ & 3 & 13 & & $x$ \\
\hline Raja polystigma Regan, 1923 & & $x$ & & $85-237$ & & 7 & & $x$ \\
\hline Scyliorhinus canicula (Linnaeus, 1758) & & $x$ & & $88-459$ & & 33 & & $x$ \\
\hline Squalus blainville (Risso, 1827) & & $x$ & & $85-328$ & & 13 & & $x$ \\
\hline \multicolumn{9}{|l|}{ ACTINOPTERI } \\
\hline Acantholabrus sp. & & $X$ & & 298 & & & & $X$ \\
\hline Actinopteri * & $x$ & & $x$ & $394-760$ & & & & $x$ \\
\hline Alepocephalus rostratus Risso, 1820 & & & $x$ & 759 & & 7 & & \\
\hline Anthias (Linnaeus, 1758) & $x$ & $x$ & $x$ & 235 & & & 7 & $x$ \\
\hline Arctozenus risso (Bonaparte, 1840) & & $X$ & $X$ & $510-747$ & & 20 & & \\
\hline Argentina sphyraena Linnaeus, 1758 & & $x$ & & $328-393$ & & 13 & & \\
\hline Argyropelecus hemigymnus Сocco, 1829 & $x$ & $x$ & $x$ & $288-1028$ & 14 & 83 & & \\
\hline $\begin{array}{l}\text { Arnoglossus imperialis } \\
\text { (Rafinesque, 1810) }\end{array}$ & & $x$ & $x$ & $105-147$ & 12 & & & $x$ \\
\hline Arnoglossus laterna (Walbaum, 1792) & & $x$ & $x$ & $122-153$ & 8 & & & \\
\hline Arnoglossus rueppelii (Cocco, 1844) & $x$ & $x$ & $x$ & $105-511$ & 21 & 7 & 5 & $x$ \\
\hline Arnoglossus thori Kyle, 1913 & & $x$ & $x$ & 98-147 & 5 & & & \\
\hline Arnoglossus sp. * & & $x$ & & $169-290$ & & & & $x$ \\
\hline Aulopus filamentosus (Bloch, 1792) & & $x$ & $x$ & $89-311$ & & & & $X$ \\
\hline Bathophilus nigerrimus Giglioli, 1882 & & & $x$ & 760 & & 7 & & \\
\hline $\begin{array}{c}\text { Bathypterois mediterraneus } \\
\text { Bauchot, } 1962\end{array}$ & & & $x$ & $756-759$ & & 20 & & $x$ \\
\hline $\begin{array}{c}\text { Benthocometes robustus (Goode \& } \\
\text { Bean, 1886) }\end{array}$ & & $x$ & & 615 & & 7 & & \\
\hline Benthosema glaciale (Reinhardt, 1837) & $x$ & $x$ & $x$ & $292-768$ & 6 & 37 & & \\
\hline Blennius ocellaris Linnaeus, 1758 & & $x$ & & 100 & & & 7 & \\
\hline $\begin{array}{c}\text { Buenia massutii Kovacic, Ordines \& } \\
\text { Schliewen, } 2017\end{array}$ & & $x$ & & $105-116$ & 17 & & & \\
\hline Callanthias ruber (Rafinesque, 1810) & & & $x$ & 160 & & & 5 & $x$ \\
\hline $\begin{array}{l}\text { Callionymus maculatus } \\
\text { Rafinesque, } 1810\end{array}$ & $x$ & $X$ & $x$ & $122-299$ & 8 & & & \\
\hline Capros aper (Linnaeus, 1758) & $X$ & $x$ & $x$ & $105-770$ & 16 & 53 & & $x$ \\
\hline Cataetyx alleni (Byrne, 1906) & & & $x$ & 729 & & 7 & & \\
\hline Centracanthus cirrus Rafinesque, 1810 & & $x$ & & 237 & & 7 & & \\
\hline Centrolophus niger (Gmelin, 1789) & & & $x$ & 747 & & 7 & & \\
\hline Cepola macrophthalma (Linnaeus, 1758) & & & $x$ & 150 & 3 & & & \\
\hline Ceratoscopelus maderensis (Lowe, 1839) & $X$ & $x$ & $x$ & $290-760$ & 4 & 27 & & \\
\hline $\begin{array}{l}\text { Chauliodus sloani Bloch \& } \\
\text { Schneider, } 1801\end{array}$ & $x$ & $x$ & $x$ & $290-1028$ & 4 & 47 & & \\
\hline $\begin{array}{l}\text { Chelidonichthys cuculus } \\
\text { (Linnaeus, 1758) }\end{array}$ & & $x$ & $x$ & $98-328$ & 20 & 13 & & \\
\hline
\end{tabular}


Table A7. Cont.

\begin{tabular}{|c|c|c|c|c|c|c|c|c|}
\hline & \multicolumn{3}{|c|}{ Area } & \multicolumn{5}{|c|}{ Sampling method } \\
\hline & SO & AM & EB & Depth (m) & BT & GOC & RD & ROV \\
\hline $\begin{array}{l}\text { Chelidonichthys lastoviza } \\
\text { (Bonnaterre, 1788) }\end{array}$ & & $x$ & $x$ & $85-127$ & & & & $x$ \\
\hline Chlopsis bicolor Rafinesque, 1810 & & $x$ & & $328-444$ & & 13 & & \\
\hline $\begin{array}{l}\text { Chlorophthalmus agassizi } \\
\text { Bonaparte, } 1840\end{array}$ & $x$ & $x$ & $x$ & $277-750$ & 8 & 17 & & $x$ \\
\hline Coelorinchus caelorhincus (Risso, 1810) & $x$ & $x$ & $x$ & $328-574$ & 12 & 47 & & $x$ \\
\hline Conger conger (Linnaeus, 1758) & $x$ & $x$ & $X$ & $328-760$ & 4 & 47 & & $x$ \\
\hline Coris sp. & & & $x$ & 102 & & & & $x$ \\
\hline Cubiceps gracilis (Lowe, 1843) & & & $x$ & 732 & & 7 & & \\
\hline $\begin{array}{c}\text { Cyclothone braueri Jespersen \& } \\
\text { Tåning, } 1926\end{array}$ & $X$ & & & 715 & 4 & & & \\
\hline $\begin{array}{l}\text { Deltentosteus quadrimaculatus } \\
\text { (Valenciennes, 1837) }\end{array}$ & & & $x$ & 412 & 3 & & & \\
\hline Diaphus holti Tåning, 1918 & & $x$ & $x$ & $459-757$ & & 13 & & \\
\hline Diaphus rafinesquii (Cocco, 1838) & & & $x$ & 757 & & 7 & & \\
\hline $\begin{array}{l}\text { Diplecogaster bimaculata } \\
\text { (Bonnaterre, 1788) }\end{array}$ & & $x$ & $x$ & $98-500$ & 20 & & & \\
\hline Dysomma brevirostre (Facciolà, 1887) & & $x$ & & $444-510$ & & 13 & & \\
\hline Echiodon dentatus (Cuvier, 1829) & & $x$ & & 459 & & 7 & & \\
\hline Electrona risso (Cocco, 1829) & & $x$ & & 459 & & 7 & & \\
\hline Epigonus constanciae (Giglioli, 1880) & & $x$ & $x$ & $444-511$ & 3 & 7 & & \\
\hline Epigonus denticulatus Dieuzeide, 1950 & & $x$ & $x$ & $393-759$ & & 30 & & \\
\hline Epigonus telescopus (Risso, 1810) & & & $x$ & $732-757$ & & 20 & & \\
\hline Epigonus sp. * & $x$ & & & 283 & & & & $X$ \\
\hline Gadella maraldi (Risso, 1810) & & $x$ & $x$ & $444-760$ & & 27 & & \\
\hline Gadiculus argenteus Guichenot, 1850 & $X$ & $X$ & $X$ & $277-542$ & 14 & 47 & & $X$ \\
\hline Gadidae* & $x$ & & & 306 & & & & $x$ \\
\hline Gaidropsarus biscayensis (Collett, 1890) & $x$ & $x$ & $x$ & $147-768$ & 15 & 23 & & \\
\hline $\begin{array}{l}\text { Glossanodon leioglossus } \\
\text { (Valenciennes, 1848) }\end{array}$ & & $x$ & & $237-459$ & 3 & 13 & & $x$ \\
\hline Gnathophis mystax (Delaroche, 1809) & & $X$ & $X$ & $112-288$ & 3 & & & $X$ \\
\hline Gobiidae* & & $x$ & $x$ & $129-603$ & & & & $x$ \\
\hline $\begin{array}{c}\text { Gymnesigobius medits Kovačić, } \\
\text { Ordines, Ramirez-Amaro \& } \\
\text { Schliewen, } 2019\end{array}$ & & & $x$ & $395-511$ & 6 & & & \\
\hline $\begin{array}{l}\text { Helicolenus dactylopterus } \\
\quad \text { (Delaroche, 1809) }\end{array}$ & $x$ & $x$ & $x$ & $259-732$ & 18 & 30 & 5 & $x$ \\
\hline $\begin{array}{c}\text { Hoplostethus mediterraneus } \\
\text { Cuvier, } 1829\end{array}$ & $x$ & $x$ & $x$ & $444-768$ & 9 & 80 & & $x$ \\
\hline Hygophum benoiti (Cocco, 1838) & & $x$ & $x$ & $393-1028$ & & 23 & & \\
\hline Hymenocephalus italicus Giglioli, 1884 & $x$ & $x$ & $x$ & $393-768$ & 5 & 87 & & $x$ \\
\hline Lampanyctus crocodilus (Risso, 1810) & & $X$ & $x$ & $444-1028$ & 3 & 87 & & $x$ \\
\hline Lampanyctus pusillus (Johnson, 1890) & & $x$ & $x$ & $288-770$ & 6 & 27 & & \\
\hline
\end{tabular}


Table A7. Cont.

\begin{tabular}{|c|c|c|c|c|c|c|c|c|}
\hline & \multicolumn{3}{|c|}{ Area } & \multicolumn{5}{|c|}{ Sampling method } \\
\hline & SO & AM & EB & Depth (m) & BT & GOC & RD & ROV \\
\hline Lebetus guilleti (Le Danois, 1913) & & $x$ & & 225 & 3 & & & \\
\hline Lepidion lepidion (Risso, 1810) & & & $x$ & $747-768$ & & 47 & & $x$ \\
\hline Lepidopus caudatus (Euphrasen, 1788) & & $x$ & & $328-460$ & & 27 & & \\
\hline Lepidorhombus boscii (Risso, 1810) & $x$ & $x$ & $x$ & $195-600$ & 14 & 53 & & $x$ \\
\hline $\begin{array}{l}\text { Lepidorhombus whiffiagonis } \\
\text { (Walbaum, 1792) }\end{array}$ & & $x$ & $x$ & $225-615$ & 3 & 20 & & $x$ \\
\hline Lepidorhombus sp. * & $x$ & $x$ & $x$ & 240 & & & & $x$ \\
\hline Lepidotrigla cavillone (Lacepède, 1801) & & $x$ & & $105-114$ & 10 & & & \\
\hline $\begin{array}{c}\text { Lepidotrigla dieuzeidei Blanc \& } \\
\text { Hureau, } 1973\end{array}$ & & $X$ & & $124-328$ & 3 & 13 & & \\
\hline Lepidotrigla sp. ${ }^{*}$ & & $x$ & & 287 & & & & $x$ \\
\hline Lestidiops sphyrenoides (Risso, 1820) & & $x$ & & 393 & & 7 & & \\
\hline Lobianchia dofleini (Zugmayer, 1911) & $x$ & $x$ & $x$ & $393-1028$ & 5 & 60 & & \\
\hline Lophius budegassa Spinola, 1807 & & $x$ & $x$ & $113-510$ & 5 & 33 & & \\
\hline Lophius piscatorius Linnaeus, 1758 & & $x$ & $x$ & $146-760$ & 3 & 17 & & \\
\hline Lophius sp. ${ }^{*}$ & & $x$ & & 103 & & & & $x$ \\
\hline $\begin{array}{l}\text { Macroramphosus scolopax } \\
\text { (Linnaeus, 1758) }\end{array}$ & & $x$ & $x$ & $112-328$ & 3 & 13 & & \\
\hline Maurolicus muelleri (Gmelin, 1789) & & $x$ & & 328 & & 7 & & \\
\hline Merluccius merluccius (Linnaeus, 1758) & & $X$ & & $237-663$ & 3 & 67 & & \\
\hline $\begin{array}{l}\text { Microchirus variegatus } \\
\text { (Donovan, 1808) }\end{array}$ & & $x$ & & 114 & 3 & & & \\
\hline Micromesistius poutassou (Risso, 1827) & & $x$ & & 328 & & 7 & & $X$ \\
\hline Molva dypterygia (Pennant, 1784) & & $x$ & & $393-459$ & & 20 & & \\
\hline Mora moro (Risso, 1810) & & & $x$ & 759 & 3 & & & \\
\hline Muraena helena & & & $X$ & 99 & & & & $\mathrm{X}$ \\
\hline $\begin{array}{l}\text { Myctophum punctatum } \\
\text { Rafinesque, } 1810\end{array}$ & & $x$ & $x$ & $444-768$ & 3 & 23 & & $x$ \\
\hline Naucrates ductor (Linnaeus, 1758) & & & $x$ & 1028 & & 7 & & \\
\hline $\begin{array}{l}\text { Nettastoma melanurum } \\
\text { Rafinesque, } 1810\end{array}$ & $x$ & $x$ & $x$ & $600-760$ & 4 & 40 & & $x$ \\
\hline Nezumia aequalis (Günther, 1878) & $x$ & $x$ & $x$ & $460-760$ & 8 & 70 & & $x$ \\
\hline Notacanthus bonaparte Risso, 1840 & $x$ & $x$ & $X$ & $600-729$ & 4 & 13 & & $X$ \\
\hline Notoscopelus elongatus (Costa, 1844) & & $x$ & $x$ & $328-759$ & & 23 & & \\
\hline Ophidion barbatum Linnaeus, 1758 & & $x$ & & 122 & 3 & & & \\
\hline Pagellus bogaraveo (Brünnich, 1768) & & $x$ & & $342-446$ & & & & $x$ \\
\hline $\begin{array}{l}\text { Peristedion cataphractum } \\
\quad \text { (Linnaeus, } 1758 \text { ) }\end{array}$ & $x$ & $x$ & $x$ & $143-328$ & 4 & 13 & & $x$ \\
\hline Phycis blennoides (Brünnich, 1768) & $X$ & $x$ & $x$ & $288-768$ & 11 & 87 & & $x$ \\
\hline $\begin{array}{l}\text { Polyacanthonotus rissoanus (De Filippi } \\
\text { \& Verany, 1857) }\end{array}$ & & & $x$ & 759 & & 7 & & \\
\hline
\end{tabular}


Table A7. Cont.

\begin{tabular}{|c|c|c|c|c|c|c|c|c|}
\hline & \multicolumn{3}{|c|}{ Area } & \multicolumn{5}{|c|}{ Sampling method } \\
\hline & SO & $\mathbf{A M}$ & EB & Depth (m) & BT & GOC & RD & ROV \\
\hline $\begin{array}{l}\text { Polyprion americanus (Bloch \& } \\
\text { Schneider, 1801) }\end{array}$ & & & $x$ & $802-813$ & & & & $x$ \\
\hline $\begin{array}{l}\text { Protogrammus alboranensis Fricke, } \\
\text { Ordines, Farias \& García-Ruiz, } 2016\end{array}$ & & $x$ & $x$ & 105-195 & 13 & & 10 & \\
\hline Scorpaena elongata Cadenat, 1943 & & $x$ & & $393-444$ & & 13 & & \\
\hline Scorpaena loppei Cadenat, 1943 & & $x$ & & 99 & & & 7 & \\
\hline Scorpaena scrofa Linnaeus, 1758 & & $X$ & $x$ & $105-276$ & & & & $x$ \\
\hline Serranus cabrilla (Linnaeus, 1758) & & $X$ & $X$ & $100-133$ & & & & $X$ \\
\hline Stomias boa boa (Risso, 1810) & & $x$ & $x$ & $393-770$ & & 47 & & \\
\hline Symbolophorus veranyi (Moreau, 1888) & & $x$ & $x$ & $393-756$ & & 10 & & \\
\hline Symphurus ligulatus (Cocco, 1844) & $X$ & $X$ & $X$ & $600-732$ & 3 & 20 & & $x$ \\
\hline $\begin{array}{l}\text { Symphurus nigrescens } \\
\text { Rafinesque, } 1810\end{array}$ & $x$ & $x$ & $x$ & $290-548$ & 7 & 33 & & $x$ \\
\hline Symphurus sp. * & & $x$ & $x$ & $242-760$ & & & & $x$ \\
\hline Synchiropus phaeton (Günther, 1861) & $x$ & $X$ & $x$ & $122-489$ & 16 & 20 & & $x$ \\
\hline Trachurus picturatus (Bowdich, 1825) & & $x$ & & $237-600$ & & 20 & & \\
\hline Trachurus trachurus (Linnaeus, 1758) & & $x$ & & $237-542$ & & 53 & & \\
\hline $\begin{array}{l}\text { Trachyrincus scabrus } \\
\text { (Rafinesque, 1810) }\end{array}$ & & $x$ & $x$ & $631-754$ & & 13 & & \\
\hline $\begin{array}{c}\text { Trachyscorpia cristulata echinata } \\
\text { (Köhler, 1896) }\end{array}$ & & & $x$ & 826 & & & & $x$ \\
\hline Trigla lyra Linnaeus, 1758 & & $x$ & $x$ & $237-393$ & 7 & 20 & & $x$ \\
\hline Triglidae * & & $x$ & $x$ & $107-169$ & & & & $x$ \\
\hline Vinciguerria attenuata (Cocco, 1838) & & $X$ & & 459 & & 7 & & \\
\hline
\end{tabular}

\section{Appendix $\mathrm{H}$}

Table A8. SIMPER results of the assemblages (see codes in Figure 7) identified from multi-variant analysis of samples obtained with beam trawl, rock dredge, and experimental bottom trawl in the Ses Olives, Ausias March, and Emile Baudot seamounts and adjacent area of the Mallorca Channel (Balearic Islands, western Mediterranean), showing the average standardized biomass (B: $\mathrm{g} / 500 \mathrm{~m}^{2}$ ), abundance (A: individuals $/ \mathrm{km}^{2}$ ) and occurrence (Occurr), the similarity (Sim), and the percentage contribution to the similarity (\%Sim) of the main species or taxa contributing up to $90 \%$ of withingroup similarity. Both abundance and biomass values were square root transformed.

\begin{tabular}{|c|c|c|c|c|}
\hline Species & B & Sim & $\% \operatorname{Sim}$ & $\Sigma \% \operatorname{Sim}$ \\
\hline \multicolumn{5}{|l|}{ BT-a (Sim: $24.0 \%$ ) } \\
\hline Corallinaceae & 4.62 & 2.47 & 10.07 & 10.07 \\
\hline Inachus dorsettensis & 1.46 & 0.94 & 3.84 & 13.91 \\
\hline Poecillastra compressa & 1.79 & 0.82 & 3.36 & 17.27 \\
\hline Ergasticus clouei & 1.19 & 0.82 & 3.34 & 20.61 \\
\hline Gryphus vitreus & 1.59 & 0.76 & 3.11 & 23.72 \\
\hline Anapagurus laevis & 1.20 & 0.74 & 3.04 & 26.76 \\
\hline
\end{tabular}


Table A8. Cont.

\begin{tabular}{|c|c|c|c|c|}
\hline Species & B & Sim & $\% \operatorname{Sim}$ & $\Sigma \% \operatorname{Sim}$ \\
\hline Distolambrus maltzami & 1.01 & 0.73 & 2.99 & 29.74 \\
\hline Hexadella sp. & 2.63 & 0.72 & 2.95 & 32.69 \\
\hline Dardanus arrosor & 1.16 & 0.67 & 2.74 & 35.44 \\
\hline Cidaris cidaris & 1.24 & 0.60 & 2.45 & 37.88 \\
\hline Peltaster placenta & 1.21 & 0.59 & 2.42 & 40.30 \\
\hline Porifera sp. 1 & 1.50 & 0.56 & 2.3 & 42.61 \\
\hline Chelidonichthys cuculus & 1.25 & 0.44 & 1.81 & 44.41 \\
\hline Pagurus prideaux & 0.87 & 0.44 & 1.80 & 46.21 \\
\hline Pomatoceros triqueter & 0.86 & 0.43 & 1.76 & 47.97 \\
\hline Ebalia tuberosa & 0.86 & 0.41 & 1.69 & 49.66 \\
\hline Anseropoda placenta & 0.73 & 0.41 & 1.67 & 51.34 \\
\hline Lophogaster typicus & 0.67 & 0.39 & 1.58 & 52.92 \\
\hline Parthenopoides massena & 0.82 & 0.39 & 1.58 & 54.5 \\
\hline Luidia sarsii & 0.79 & 0.38 & 1.54 & 56.05 \\
\hline Eurynome aspera & 0.73 & 0.37 & 1.51 & 57.56 \\
\hline Sclerasterias richardi & 0.74 & 0.36 & 1.47 & 59.03 \\
\hline Chaetaster longipes & 0.82 & 0.36 & 1.46 & 60.49 \\
\hline Chelonaplysilla psammophyla & 1.11 & 0.34 & 1.40 & 61.90 \\
\hline Penares helleri & 1.30 & 0.34 & 1.40 & 63.29 \\
\hline Argyrotheca chordata & 1.19 & 0.34 & 1.37 & 64.67 \\
\hline Axinella spp. & 0.94 & 0.32 & 1.31 & 65.97 \\
\hline Marthasterias glacialis & 0.73 & 0.31 & 1.27 & 67.25 \\
\hline Pseudamussium clavatum & 0.56 & 0.28 & 1.16 & 68.40 \\
\hline Ancorinidae spp. & 1.10 & 0.28 & 1.14 & 69.54 \\
\hline Calappa granulata & 1.02 & 0.27 & 1.10 & 70.64 \\
\hline Ebalia nux & 0.70 & 0.26 & 1.06 & 71.70 \\
\hline Haliclona poecillastroides & 0.96 & 0.26 & 1.04 & 72.75 \\
\hline Mergelia truncata & 0.94 & 0.25 & 1.01 & 73.76 \\
\hline Monodaeus couchii & 0.62 & 0.23 & 0.94 & 74.71 \\
\hline Macropipus tuberculatus & 0.55 & 0.23 & 0.94 & 75.65 \\
\hline Gracilechinus acutus & 0.51 & 0.21 & 0.84 & 76.49 \\
\hline Petrosia (Petrosia) raphida & 1.02 & 0.20 & 0.83 & 77.32 \\
\hline Ranella olearium & 0.81 & 0.19 & 0.77 & 78.09 \\
\hline Axinellidae & 0.70 & 0.19 & 0.76 & 78.85 \\
\hline Calyx sp. & 1.20 & 0.18 & 0.72 & 79.57 \\
\hline Hyalinoecia tubicola & 0.81 & 0.17 & 0.69 & 80.26 \\
\hline Astrophorina sp. 2 & 0.88 & 0.16 & 0.65 & 80.91 \\
\hline Ebalia deshayesi & 0.37 & 0.16 & 0.65 & 81.56 \\
\hline Ophiomyces grandis & 0.49 & 0.15 & 0.60 & 82.17 \\
\hline Calliostoma granulatum & 0.41 & 0.13 & 0.52 & 82.69 \\
\hline Polychaeta & 0.42 & 0.13 & 0.51 & 83.20 \\
\hline
\end{tabular}


Table A8. Cont.

\begin{tabular}{|c|c|c|c|c|}
\hline Species & B & Sim & $\% \operatorname{Sim}$ & $\Sigma \% \operatorname{Sim}$ \\
\hline Dragmatella aberrans & 0.72 & 0.12 & 0.50 & 83.70 \\
\hline Ophiopsila aranea & 0.35 & 0.12 & 0.47 & 84.17 \\
\hline Arnoglossus imperialis & 0.49 & 0.11 & 0.46 & 84.64 \\
\hline Philine monterosati & 0.32 & 0.11 & 0.45 & 85.09 \\
\hline Sepia elegans & 0.41 & 0.11 & 0.44 & 85.53 \\
\hline Arnoglossus rueppelii & 0.50 & 0.11 & 0.43 & 85.97 \\
\hline Parastichopus regalis & 0.48 & 0.11 & 0.43 & 86.40 \\
\hline Diplecogaster bimaculata & 0.35 & 0.10 & 0.42 & 86.81 \\
\hline Petrosia ficiformis & 0.86 & 0.10 & 0.41 & 87.23 \\
\hline Desmacella inornata & 0.66 & 0.10 & 0.39 & 87.61 \\
\hline Cuspidaria rostrata & 0.33 & 0.09 & 0.38 & 88.00 \\
\hline Porifera sp. 2 & 0.83 & 0.09 & 0.38 & 88.38 \\
\hline Ophiura (Dictenophiura) carnea & 0.25 & 0.09 & 0.38 & 88.75 \\
\hline Vulcanella aberrans & 0.69 & 0.08 & 0.35 & 89.10 \\
\hline Lanice conchilega & 0.43 & 0.08 & 0.34 & 89.44 \\
\hline Aphroditidae & 0.30 & 0.08 & 0.21 & 89.78 \\
\hline Marginaster capreensis & 0.43 & 0.08 & 0.34 & 90.11 \\
\hline \multicolumn{5}{|l|}{ BT-b (Sim: $21.9 \%$ ) } \\
\hline Lophogaster typicus & 1.08 & 1.60 & 7.32 & 7.32 \\
\hline Ebalia nux & 0.94 & 1.47 & 6.75 & 14.08 \\
\hline Desmacella inornata & 1.38 & 1.35 & 6.18 & 20.25 \\
\hline Gryphus vitreus & 1.58 & 1.12 & 5.14 & 25.39 \\
\hline Thenea muricata & 0.92 & 1.02 & 4.66 & 30.05 \\
\hline Plesionika antigai & 0.88 & 0.96 & 4.40 & 34.46 \\
\hline Ergasticus clouei & 0.70 & 0.82 & 3.74 & 38.20 \\
\hline Ophiura (Dictenophiura) carnea & 0.65 & 0.70 & 3.22 & 41.42 \\
\hline Desmacella annexa & 0.69 & 0.50 & 2.30 & 43.72 \\
\hline Sepietta oweniana & 0.68 & 0.44 & 2.03 & 45.75 \\
\hline Pseudostichopus occultatus & 0.74 & 0.40 & 1.83 & 47.58 \\
\hline Monodaeus couchii & 0.40 & 0.38 & 1.76 & 49.34 \\
\hline Parapenaeus longirostris & 0.58 & 0.36 & 1.63 & 50.97 \\
\hline Plesionika martia & 0.49 & 0.35 & 1.61 & 52.58 \\
\hline Antalis sp. & 0.40 & 0.35 & 1.60 & 54.18 \\
\hline Ophiomyces grandis & 0.54 & 0.34 & 1.58 & 55.75 \\
\hline Alpheus glaber & 0.47 & 0.33 & 1.51 & 57.26 \\
\hline Chlorotocus crassicornis & 0.49 & 0.32 & 1.47 & 58.74 \\
\hline Cuspidaria rostrata & 0.31 & 0.32 & 1.47 & 60.21 \\
\hline Amphiura filiformis & 0.38 & 0.31 & 1.40 & 61.61 \\
\hline Bathyarca philippiana & 0.35 & 0.29 & 1.35 & 62.96 \\
\hline Helicolenus dactylopterus & 0.66 & 0.28 & 1.26 & 64.22 \\
\hline Anapagurus laevis & 0.33 & 0.26 & 1.20 & 65.42 \\
\hline
\end{tabular}


Table A8. Cont.

\begin{tabular}{|c|c|c|c|c|}
\hline Species & B & Sim & $\% \operatorname{Sim}$ & $\Sigma \%$ Sim \\
\hline Hyalinoecia tubicola & 0.54 & 0.24 & 1.09 & 66.51 \\
\hline Polychaeta sp. 1 & 0.42 & 0.23 & 1.06 & 67.57 \\
\hline Lepidorhombus boscii & 0.57 & 0.23 & 1.05 & 68.62 \\
\hline Luidia sarsii & 0.36 & 0.22 & 1.01 & 69.63 \\
\hline Processa canaliculata & 0.38 & 0.22 & 0.99 & 70.62 \\
\hline Poecillastra compressa & 0.44 & 0.22 & 0.99 & 71.61 \\
\hline Bubaris sp. & 0.50 & 0.20 & 0.94 & 72.55 \\
\hline Plesionika gigliolii & 0.42 & 0.19 & 0.88 & 73.43 \\
\hline Porifera sp. 1 & 0.54 & 0.19 & 0.24 & 74.30 \\
\hline Munida speciosa & 0.34 & 0.18 & 0.84 & 75.14 \\
\hline Plesionika heterocarpus & 0.35 & 0.18 & 0.81 & 75.96 \\
\hline Gadiculus argenteus & 0.35 & 0.17 & 0.76 & 76.72 \\
\hline Cymonomus granulatus & 0.23 & 0.16 & 0.73 & 77.45 \\
\hline Ophiocten abyssicolum & 0.30 & 0.16 & 0.72 & 78.17 \\
\hline Solenocera membranacea & 0.30 & 0.15 & 0.70 & 78.87 \\
\hline Aegaeon lacazei & 0.27 & 0.15 & 0.68 & 79.55 \\
\hline Pagurus alatus & 0.23 & 0.14 & 0.66 & 80.21 \\
\hline Abra longicallus & 0.21 & 0.14 & 0.63 & 80.84 \\
\hline Synchiropus phaeton & 0.35 & 0.13 & 0.59 & 81.43 \\
\hline Coelorinchus caelorhincus & 0.29 & 0.13 & 0.58 & 82.02 \\
\hline Dragmatella aberrans & 0.37 & 0.13 & 0.58 & 82.60 \\
\hline Philocheras echinulatus & 0.24 & 0.12 & 0.57 & 83.17 \\
\hline Calliostoma granulatum & 0.24 & 0.12 & 0.56 & 83.73 \\
\hline Sipunculidae sp. 1 & 0.25 & 0.12 & 0.25 & 84.28 \\
\hline Sclerasterias richardi & 0.23 & 0.12 & 0.55 & 84.83 \\
\hline Cidaris & 0.28 & 0.12 & 0.55 & 85.38 \\
\hline Hamacantha (Vomerula) sp. & 0.30 & 0.12 & 0.55 & 85.92 \\
\hline Inachus dorsettensis & 0.25 & 0.11 & 0.51 & 86.44 \\
\hline Sipunculidae sp. 2 & 0.33 & 0.11 & 0.51 & 86.94 \\
\hline Polychaeta sp 2 & 0.23 & 0.11 & 0.49 & 87.43 \\
\hline Euspira fusca & 0.29 & 0.11 & 0.48 & 87.92 \\
\hline Processa nouveli & 0.23 & 0.10 & 0.46 & 88.38 \\
\hline Anthozoa & 0.22 & 0.10 & 0.46 & 88.84 \\
\hline Arnoglossus rueppelii & 0.29 & 0.10 & 0.44 & 89.28 \\
\hline Chlorophthalmus agassizi & 0.31 & 0.10 & 0.44 & 89.72 \\
\hline Aporrhais serresiana & 0.29 & 0.09 & 0.42 & 90.14 \\
\hline \multicolumn{5}{|l|}{ BT-c (Sim: $33.4 \%$ ) } \\
\hline Geryon longipes & 1.83 & 6.31 & 18.91 & 18.91 \\
\hline Polycheles typhlops & 1.38 & 5.56 & 16.67 & 35.58 \\
\hline Calocaris macandreae & 1.20 & 4.57 & 13.70 & 49.28 \\
\hline Plesionika acanthonotus & 0.78 & 2.50 & 7.48 & 56.76 \\
\hline
\end{tabular}


Table A8. Cont.

\begin{tabular}{|c|c|c|c|c|}
\hline Species & B & Sim & $\%$ Sim & $\Sigma \% \operatorname{Sim}$ \\
\hline Antalis $s p$ & 0.68 & 1.81 & 5.41 & 62.18 \\
\hline Munida perarmata & 0.67 & 1.61 & 4.84 & 67.01 \\
\hline Monodaeus couchii & 0.49 & 1.18 & 3.52 & 70.53 \\
\hline Eusergestes arcticus & 0.45 & 1.16 & 3.48 & 74.01 \\
\hline Thenea muricata & 0.56 & 1.00 & 3.01 & 77.02 \\
\hline Nezumia aequalis & 0.67 & 0.96 & 2.87 & 79.89 \\
\hline Isidella elongata & 0.89 & 0.79 & 2.36 & 82.25 \\
\hline Gryphus vitreus & 0.68 & 0.76 & 2.26 & 84.51 \\
\hline Plesionika martia & 0.57 & 0.70 & 2.09 & 86.60 \\
\hline Gennadas elegans & 0.29 & 0.55 & 1.66 & 88.26 \\
\hline Abra longicallus & 0.32 & 0.45 & 1.34 & 89.60 \\
\hline Robustosergia robusta & 0.30 & 0.43 & 1.30 & 90.90 \\
\hline \multicolumn{5}{|l|}{ RD-a (Sim: 21.84\%) } \\
\hline Corallinaceae & 0.95 & 7.40 & 30.45 & 30.45 \\
\hline Megerlia truncata & 0.90 & 5.63 & 23.15 & 53.60 \\
\hline Argyrotheca cordata & 0.75 & 3.97 & 16.34 & 69.94 \\
\hline Porifera & 0.65 & 2.18 & 8.98 & 78.92 \\
\hline Axinella spp. & 0.40 & 0.80 & 3.27 & 82.20 \\
\hline Hyalinoecia tubicola & 0.30 & 0.52 & 2.16 & 84.35 \\
\hline Cnidaria & 0.30 & 0.34 & 1.41 & 85.76 \\
\hline Palmophyllum crassum & 0.25 & 0.26 & 1.07 & 86.83 \\
\hline Jaspis spp. & 0.25 & 0.20 & 0.84 & 87.67 \\
\hline Bebryce mollis & 0.20 & 0.19 & 0.80 & 88.47 \\
\hline Viminella sp. & 0.15 & 0.19 & 0.79 & 89.26 \\
\hline Monodaeus couchii & 0.20 & 0.15 & 0.62 & 90.60 \\
\hline \multicolumn{5}{|l|}{ RD-b (Sim: 15.35\%) } \\
\hline Plesionika gigliolii & 0.67 & 5.26 & 34.29 & 34.29 \\
\hline Asperarca nodulosa & 0.58 & 4.74 & 30.87 & 65.16 \\
\hline Plesionika antigai & 0.33 & 1.10 & 7.18 & 72.34 \\
\hline Ebalia nux & 0.33 & 0.79 & 5.13 & 77.47 \\
\hline Plesionika narval & 0.25 & 0.66 & 4.28 & 81.74 \\
\hline Bathyarca philippiana & 0.25 & 0.61 & 3.95 & 85.69 \\
\hline Argyrotheca chordata & 0.25 & 0.45 & 2.91 & 88.60 \\
\hline Ophiura (Dictenophiura) carnea & 0.25 & 0.31 & 2.04 & 90.64 \\
\hline \multicolumn{5}{|l|}{ D-c (Sim: $23.63 \%)$} \\
\hline Porifera & 1.00 & 12.41 & 52.54 & 52.54 \\
\hline Asperarca nodulosa & 0.60 & 2.72 & 11.50 & 64.04 \\
\hline Callyspongiidae & 0.50 & 1.76 & 7.46 & 71.50 \\
\hline Haliclona poecillastroides & 0.50 & 1.65 & 7.00 & 78.50 \\
\hline Hamacantha sp. & 0.40 & 1.37 & 5.80 & 84.29 \\
\hline Jaspis spp. & 0.40 & 1.10 & 4.67 & 88.96 \\
\hline Cnidaria & 0.30 & 0.50 & 2.13 & 91.09 \\
\hline
\end{tabular}


Table A8. Cont.

\begin{tabular}{|c|c|c|c|c|}
\hline Species & B & Sim & $\% \operatorname{Sim}$ & $\Sigma \% \operatorname{Sim}$ \\
\hline \multicolumn{5}{|l|}{ GOC-a (Sim: 57.07\%) } \\
\hline Plesionika acanthonotus & 17.8 & 7.5 & 12.2 & 12.2 \\
\hline Plesionika martia & 16.25 & 6.31 & 10.26 & 22.45 \\
\hline Nezumia aequalis & 18.29 & 6.16 & 10.01 & 32.46 \\
\hline Geryon longipes & 16.05 & 6.01 & 9.77 & 42.23 \\
\hline Aristeus antennatus & 18.47 & 5.38 & 8.75 & 50.99 \\
\hline Galeus melastomus & 19.32 & 5.25 & 8.53 & 59.52 \\
\hline Hymenocephalus italicus & 12.48 & 4.57 & 7.44 & 66.96 \\
\hline Polycheles typhlops & 8.88 & 3.79 & 6.15 & 73.11 \\
\hline Robustosergia robusta & 8.87 & 3.08 & 5.01 & 78.11 \\
\hline Phycis blennoides & 6.79 & 2.6 & 4.22 & 82.34 \\
\hline Hoplostethus mediterraneus & 8.65 & 2.46 & 4 & 86.33 \\
\hline Pasiphaea multidentata & 7.68 & 1.69 & 2.74 & 89.07 \\
\hline Gennadas elegans & 4.86 & 1.24 & 2.02 & 91.09 \\
\hline \multicolumn{5}{|l|}{ GOC-b (Sim: 52.07\%) } \\
\hline Plesionika martia & 37.10 & 6.77 & 11.94 & 11.94 \\
\hline Phycis blennoides & 30.66 & 5.48 & 9.67 & 21.62 \\
\hline Hymenocephalus italicus & 34.49 & 5.20 & 9.17 & 30.78 \\
\hline Pasiphaea sivado & 30.24 & 4.10 & 7.23 & 38.02 \\
\hline Nephrops norvegicus & 16.57 & 3.74 & 6.6 & 44.62 \\
\hline Hoplostethus mediterraneus & 29.46 & 3.50 & 6.17 & 50.78 \\
\hline Helicolenus dactylopterus & 17.77 & 3.42 & 6.04 & 56.82 \\
\hline Parapenaeus longirostris & 31.43 & 2.94 & 5.19 & 62.01 \\
\hline Processa canaliculata & 14.44 & 2.84 & 5.01 & 67.03 \\
\hline Chlorotocus crassicornis & 12.31 & 2.47 & 4.36 & 71.39 \\
\hline Munida perarmata & 10.57 & 1.94 & 3.42 & 74.81 \\
\hline Gaidropsarus biscayensis & 8.12 & 1.80 & 3.17 & 77.98 \\
\hline Coelorinchus caelorhincus & 20.71 & 1.43 & 2.52 & 80.50 \\
\hline Gadiculus argenteus & 22.21 & 1.43 & 2.52 & 83.02 \\
\hline Lepidorhombus boscii & 11.13 & 1.24 & 2.18 & 85.20 \\
\hline Calocaris macandreae & 9.66 & 1.04 & 1.83 & 87.03 \\
\hline Sepietta oweniana & 18.15 & 1.01 & 1.78 & 88.81 \\
\hline Merluccius merluccius & 8.28 & 1.01 & 1.78 & 90.59 \\
\hline \multicolumn{5}{|l|}{ GOC-c (Sim: 53.4\%) } \\
\hline Gadiculus argenteus & 103.87 & 10.3 & 19.28 & 19.28 \\
\hline Chlorophthalmus agassizi & 67.98 & 7.24 & 13.55 & 32.83 \\
\hline Coelorinchus caelorhincus & 87.45 & 5.85 & 10.95 & 43.78 \\
\hline Parapenaeus longirostris & 45.7 & 5.16 & 9.66 & 53.44 \\
\hline Scyliorhinus canicula & 37.35 & 3.85 & 7.21 & 60.65 \\
\hline Sepietta oweniana & 43.88 & 3.74 & 7 & 67.66 \\
\hline Helicolenus dactylopterus & 66.52 & 3.58 & 6.7 & 74.36 \\
\hline
\end{tabular}


Table A8. Cont.

\begin{tabular}{ccccc}
\hline Species & B & Sim & \%Sim & $\boldsymbol{\Sigma} \%$ Sim \\
\hline Lepidorhombus boscii & 20.56 & 1.79 & 3.35 & 77.71 \\
\hline Synchiropus phaeton & 32.23 & 1.64 & 3.07 & 80.78 \\
\hline Galeus melastomus & 30.43 & 1.3 & 2.43 & 83.21 \\
\hline Thenea muricata & 10.29 & 1.23 & 2.31 & 85.52 \\
\hline Plesionika heterocarpus & 25.14 & 1.09 & 2.04 & 87.56 \\
\hline Illex coindetii & 9.23 & 1.02 & 1.91 & 89.48 \\
\hline Desmacella annexa & 22.93 & 0.82 & 1.54 & 91.01 \\
\hline
\end{tabular}

\section{References}

1. Coll, M.; Piroddi, C.; Steenbeek, J.; Kaschner, K.; Ben Rais Lasram, F.; Aguzzi, J.; Ballesteros, E.; Bianchi, C.N.; Corbera, J.; Dailianis, T.; et al. The Biodiversity of the Mediterranean Sea: Estimates, Patterns, and Threats. PLoS ONE 2010, 5, e11842. [CrossRef]

2. Borja, Á.; Elliott, M.; Carstensen, J.; Heiskanen, A.-S.; van de Bund, W. Marine management-Towards an integrated implementation of the European Marine Strategy Framework and the Water Framework Directives. Mar. Pollut. Bull. 2010, 60, 2175-2186. [CrossRef]

3. Clark, M.R.; Schlacher, T.A.; Rowden, A.A.; Stocks, K.I.; Consalvey, M. Science Priorities for Seamounts: Research Links to Conservation and Management. PLoS ONE 2012, 7, e29232. [CrossRef] [PubMed]

4. Palomino, D.; Vázquez, J.-T.; Ercilla, G.; Alonso, B.; López-González, N.; Díaz-Del-Río, V. Interaction between seabed morphology and water masses around the seamounts on the Motril Marginal Plateau (Alboran Sea, Western Mediterranean). Geo-Mar. Lett. 2011, 31, 465-479. [CrossRef]

5. Würtz, M.; Rovere, M.; Bo, M. Introducing the Mediterranean Seamount Atlas: General aspects. In Atlas of the Mediterranean Seamounts and Seamount-like Structures; Würtz, M., Rovere, M., Eds.; IUCN: Gland, Switzerland; Málaga, Spain, 2015; pp. 11-19.

6. Report of the Technical Consultation on International Guidelines for the Management of Deep-Sea Fisheries in the High Seas; FAO: Rome, Italy, 2009.

7. Gomez-Ballesteros, M.; Vazquez, J.T.; Palomino, D.; Rovere, M.; Bo, M.; Alessi, J.; Fiori, C.; Würtz, M. Seamounts and Seamountlike Structures of the Western Mediterranean. In Atlas of the Mediterranean Seamounts and Seamount-like Structures; Würtz, M., Rovere, M., Eds.; IUCN: Gland, Switzerland; Málaga, Spain, 2015; pp. 59-109.

8. Vazquez, J.T.; Alonso, B.; Fernandez-Puga, M.C.; Gomez-Ballesteros, M.; Iglesias, J.; Palomino, D.; Roque, C.; Ercilla, G.; Díaz del Río, V. Seamounts along the Iberian continental margins. Bol. Geol. Min. 2015, 126, 483-514.

9. Rodríguez, M.G.; Esteban, A. On the biology and fishery of Aristeus antennatus (Risso, 1816), (Decapoda, Dendrobranchiata) in the Ibiza Channel (Balearic Islands, Spain). Sci. Mar. 1999, 63, 27-37. [CrossRef]

10. Rodríguez, M.G.; Esteban, A.; Gil, J.L.P. Considerations on the biology of Plesionika edwardsi (Brandt, 1851) (Decapoda, Caridea, Pandalidae) from experimental trap catches in the Spanish western Mediterranean Sea. Sci. Mar. 2000, 64, 369-379. [CrossRef]

11. Acosta, J.; Muñoz, A.; Herranz, P.; Palomo, C.; Ballesteros, M.; Vaquero, M.; Uchupi, E. Geodynamics of the Emile Baudot Escarpment and the Balearic Promontory, western Mediterranean. Mar. Pet. Geol. 2001, 18, 349-369. [CrossRef]

12. Acosta, J.; Canals, M.; Carbo, A.; Martín, A.M.; Urgeles, R.; Muñoz-Martín, A.; Uchupi, E. Sea floor morphology and PlioQuaternary sedimentary cover of the Mallorca Channel, Balearic Islands, western Mediterranean. Mar. Geol. 2004, 206, 165-179. [CrossRef]

13. Montañas Submarinas de Las Islas Baleares: Canal de Mallorca. Propuesta de Protección Para Ausias March, Emile Baudot y Ses Olives; OCEANA: Washington, DC, USA, 2011; p. 60, Unpublished work; Available online: https:/ /oceana.org/sites/default/files / reports/OCEANA_Montanas_submarinas_baleares_Canal_mallorca_2011_0.pdf (accessed on 15 December 2021).

14. Expedition 2014 Balearic Islands Cabrera National Park and Mallorca Channel Seamounts; OCEANA: Washington, DC, USA. 2015, p. 21, Unpublished work. Available online: https://europe.oceana.org/sites/default/files/oceana_expedition2014_balearic_ islands_eng_11.pdf (accessed on 20 December 2021).

15. Aguilar, R.; Correa, M.L.; Calcinai, B.; Pastor, X.; De La Torriente, A.; Garcia, S. First records of Asbestopluma hypogea Vacelet and Boury-Esnault, 1996 (Porifera, Demospongiae Cladorhizidae) on seamounts and in bathyal settings of the Mediterranean Sea. Zootaxa 2011, 2925, 33-40. [CrossRef]

16. Maldonado, M.; Aguilar, R.; Blanco, J.; Garcia, S.; Serrano, A.; Punzón, A. Aggregated Clumps of Lithistid Sponges: A Singular, Reef-Like Bathyal Habitat with Relevant Paleontological Connections. PLoS ONE 2015, 10, e0125378. [CrossRef]

17. Mastrototaro, F.; Chimienti, G.; Acosta, J.; Blanco, J.; Garcia, S.; Rivera, J.; Aguilar, R. Isidella elongata (Cnidaria: Alcyonacea) facies in the western Mediterranean Sea: Visual surveys and descriptions of its ecological role. Eur. Zool. J. 2017, 84, $209-225$. [CrossRef]

18. Marín, P.; Aguilar, R.; Garcia, S.; Fournier, N. A Complementary Approach for the Mediterranean N2000 in Open and Deep Sea. 2011; p. 17, Unpublished work. 
19. Acosta, J.; Canals, M.; López-Martínez, J.; Muñoz, A.; Herranz, P.; Urgeles, R.; Palomo, C.; Casamor, J.L. The Balearic Promontory geomorphology (western Mediterranean): Morphostructure and active processes. Geomorphol. 2003, 49, 177-204. [CrossRef]

20. Lehucher, P.M.; Beautier, L.; Chartier, M.; Martel, F.; Mortier, L.; Brehmer, P.; Millot, C.; Alberola, C.; Benzhora, M.; Taupier-Letage, I.; et al. Progress from 1989 to 1992 in understanding the circulation of the Western Med-iterranean Sea. Oceanol. Acta 1995, 18, 255-271.

21. Pinot, J.-M.; López-Jurado, J.; Riera, M. The CANALES experiment (1996-1998). Interannual, seasonal, and mesoscale variability of the circulation in the Balearic Channels. Prog. Oceanogr. 2002, 55, 335-370. [CrossRef]

22. Mertens, C.; Schott, F. Interannual Variability of Deep-Water Formation in the Northwestern Mediterranean. J. Phys. Oceanogr. 1998, 28, 1410-1424. [CrossRef]

23. Lafuente, J.; Jurado, J.L.L.; Lucaya, N.; Yañez, M.V.; Garcia, J. Circulation of water masses through the Ibiza Channel. Oceanol. Acta 1995, 18, 245-254.

24. Millot, C. Circulation in the Western Mediterranean Sea. J. Mar. Syst. 1999, 20, 423-442. [CrossRef]

25. Monserrat, S.; López-Jurado, J.; Marcos, M. A mesoscale index to describe the regional circulation around the Balearic Islands. J. Mar. Syst. 2008, 71, 413-420. [CrossRef]

26. Estr Estrada, M. Primary production in the northwestern Mediterranean. Sci. Mar. 1996, 60 (Suppl. 2), 55-64.

27. Bosc, E.; Bricaud, A.; Antoine, D. Seasonal and interannual variability in algal biomass and primary production in the Mediterranean Sea, as derived from 4 years of SeaWiFS observations. Glob. Biogeochem. Cycles 2004, 18. [CrossRef]

28. Pinot, J.-M.; Tintoré, J.; Gomis, D. Multivariate analysis of the surface circulation in the Balearic Sea. Prog. Oceanogr. 1995, 36, 343-376. [CrossRef]

29. De Puelles, M.L.F.; Valencia, J.; Jansá, J.; Morillas, A. Hydrographical characteristics and zooplankton distribution in the Mallorca channel (Western Mediterranean): Spring 2001. ICES J. Mar. Sci. 2004, 61, 654-666. [CrossRef]

30. López-Jurado, J.; Marcos, M.; Monserrat, S. Hydrographic conditions affecting two fishing grounds of Mallorca island (Western Mediterranean): During the IDEA Project (2003-2004). J. Mar. Syst. 2008, 71, 303-315. [CrossRef]

31. Maynou, F.; Cartes, J.E. Community structure of bathyal decapod crustaceans off south-west Balearic Islands (western Mediterranean): Seasonality and regional patterns in zonation. J. Mar. Biol. Assoc. U. K. 2000, 80, 789-798. [CrossRef]

32. Cartes, J.; Maynou, F.; Morales-Nin, B.; Massutí, E.; Moranta, J. Trophic structure of a bathyal benthopelagic boundary layer community south of the Balearic Islands (southwestern Mediterranean). Mar. Ecol. Prog. Ser. 2001, 215, 23-35. [CrossRef]

33. Rueda, L.; Moranta, J.; Abelló, P.; Balbin, R.; Barbera, C.; De Puelles, M.F.; Olivar, M.; Ordines, F.; Ramon, M.; Torres, A.; et al. Body condition of the deep water demersal resources at two adjacent oligotrophic areas of the western Mediterranean and the influence of the environmental features. J. Mar. Syst. 2014, 138, 194-202. [CrossRef]

34. Carbonell, A.; Lloret, J.; Demestre, M. Relationship between condition and recruitment success of red shrimp (Aristeus antennatus) in the Balearic Sea (Northwestern Mediterranean). J. Mar. Syst. 2008, 71, 403-412. [CrossRef]

35. Massutí, E.; Monserrat, S.; Oliver, P.; Moranta, J.; López-Jurado, J.L.; Marcos, M.; Hidalgo, M.; Guijarro, B.; Carbonell, A.; Pereda, P. The influence of oceanographic scenarios on the population dynamics of demersal resources in the western Mediterranean: Hypothesis for hake and red shrimp off Balearic Islands. J. Mar. Syst. 2008, 71, 421-438. [CrossRef]

36. Barcelona, S.G.; De Urbina, J.M.O.; De La Serna, J.M.; Alot, E.; Macías, D. Seabird bycatch in Spanish Mediterranean large pelagic longline fisheries, 2000-2008. Aquat. Living Resour. 2010, 23, 363-371. [CrossRef]

37. Gordoa, A.; Rouyer, T.; Ortiz, M. Review and update of the French and Spanish purse seine size at catch for the Mediterranean bluefin tuna fisheries 1970-2010. ICCAT Recl. Doc. Sci./Collect. Vol. Sci. Pap. 2017, 75, 1622-1633. Available online: https: / / archimer.ifremer.fr/doc/00490/60191/ (accessed on 31 October 2021).

38. Jennings, S.; Lancaster, J.; Woolmer, A.; Cotter, J. Distribution, diversity and abundance of epibenthic fauna in the North Sea. J. Mar. Biol. Assoc. U. K. 1999, 79, 385-399. [CrossRef]

39. Reiss, H.; Kröncke, I.; Ehrich, S. Estimating the catching efficiency of a 2-m beam trawl for sampling epifauna by removal experiments. ICES J. Mar. Sci. 2006, 63, 1453-1464. [CrossRef]

40. Bertrand, J.A.; Gil de Sola, L.; Papaconstantinou, C.; Relini, G.; Souplet, A. The general specifications of the MEDITS surveys. Sci. Mar. 2002, 66, 9-17. [CrossRef]

41. Spedicato, M.T.; Massutí, E.; Mérigot, B.; Tserpes, G.; Jadaud, A.; Relini, G. The MEDITS trawl survey specifications in an ecosystem approach to fishery management. Sci. Mar. 2019, 83, 9-20. [CrossRef]

42. Dremière, P.Y.; Fiorentini, L.; Cosimi, G.; Leonori, I.; Sala, A.; Spagnolo, A. Escapement from the main body of the bottom trawl used for the Mediterranean international trawl survey (MEDITS). Aquat. Living Resour. 1999, 12, 207-217. [CrossRef]

43. Fiorentini, L.; Dremière, P.-Y.; Leonori, I.; Sala, A.; Palumbo, V. Efficiency of the bottom trawl used for the Mediterranean international trawl survey (MEDITS)Efficacité du chalut de fond utilisé pour le programme international d'évaluation des ressources halieutiques de Méditerranée (MEDITS). Aquat. Living Resour. 1999, 12, 187-205. [CrossRef]

44. Guijarro, B. Population Dynamics and Assessment of Exploited Deep Water Decapods off Balearic Islands (Western MediterraNean): From Single to Multi-Species Approach. Ph.D. Thesis, University of the Balearic Islands, Palma, Spain, 2012. Available online: http:/ / www.repositorio.ieo.es/e-ieo/handle/10508/10096 (accessed on 15 December 2021).

45. Hamilton, E.L. Geoacoustic modeling of the sea floor. J. Acoust. Soc. Am. 1980, 68, 1313-1340. [CrossRef]

46. Gafeira, J.; Long, D.; Diaz-Doce, D. Semi-automated characterisation of seabed pockmarks in the central North Sea. Near Surf. Geophys. 2012, 10, 301-312. [CrossRef] 
47. Folk, R.L. The Distinction between Grain Size and Mineral Composition in Sedimentary-Rock Nomenclature. J. Geol. 1954, 62, 344-359. [CrossRef]

48. Heiri, O.; Lotter, A.F.; Lemcke, G. Loss on ignition as a method for estimating organic and carbonate content in sediments: Reproducibility and comparability of results. J. Paleolimnol. 2001, 25, 101-110. [CrossRef]

49. Sardà, F.; Calafat, A.; Flexas, M.M.; Tselepides, A.; Canals, M.; Espino, M.; Tursi, A. An introduction to Mediterranean deep-sea biology. Sci. Mar. 2004, 68, 7-38. [CrossRef]

50. Clarke, K.R.; Gorley, R.N. PRIMER v6 User Manual/Tutorial (Plymouth Routines in Multivariate Ecological Research); PRI-MER-E: Plymouth, Auckland, New Zealand, 2006; p. 192.

51. Farriols, M.T.; Ordines, F.; Hidalgo, M.; Guijarro, B.; Massutí, E. N90 index: A new approach to biodiversity based on similarity and sensitive to direct and indirect fishing impact. Ecol. Indic. 2015, 52, 245-255. [CrossRef]

52. Farriols, M.T.; Ordines, F.; Somerfield, P.J.; Pasqual, C.; Hidalgo, M.; Guijarro, B.; Massutí, E. Bottom trawl impacts on Mediterranean demersal fish diversity: Not so obvious or are we too late? Cont. Shelf Res. 2017, 137, 84-102. [CrossRef]

53. Ordines, F.; Ramón, M.; Rivera, J.; Rodríguez-Prieto, C.; Farriols, M.T.; Guijarro, B.; Pasqual, C.; Massutí, E. Why long term trawled red algae beds off Balearic Islands (western Mediterranean) still persist? Reg. Stud. Mar. Sci. 2017, 15, 39-49. [CrossRef]

54. Farriols, M.T.; Ordines, F.; Massutí, E. N90, a Diversity Index Sensitive to Variations in Beta Diversity Components. Diversity 2021, 13, 489. [CrossRef]

55. Templado, J.; Ballesteros, E.; Galparsoro, I.; Borja, A.; Serrano, A.; Martín, L.; Brito, A. Inventario Español de Hábitats y Especies Marinos. In Guía Interpretativa: Inventario Español de Hábitats Marinos; Ministerio de Agricultura, Alimentación y Medio Ambiente (España): Madrid, Spain, 2012.

56. Gerovasileiou, V.; Akel, E.K.; Akyol, O.K.A.N.; Alongi, G.; Azevedo, F.; Babali, N.; Bakiu, R.; Bariche, M.; Bennoui, A.; Castriota, L.; et al. New Mediterranean Biodiversity Records (July, 2017). Mediterr. Mar. Sci. 2017, 18, 355-384. [CrossRef]

57. Domínguez, M.; Fontán, A.; Rivera, J.; Ramón, M. Informe proyecto DRAGONSAL: Caracterización del ecosistema bentónico de la plataforma costera del área comprendida entre Sa Dragonera, Cabrera y el Cap de Ses Salines (Mallorca), Convenio específico de colaboración entre la Conselleria d'Agricultura; Medi Ambient i Territori de les Illes Balears y el Instituto Español de Oceanografía: Palma, Spain, 2013; Unpublished work.

58. Moranta, J.; Barberá, C.; Druet, M.; Zaragoza, N. Caracterización Ecológica de La Plataforma Continental (50-100 m) del Canal de Menorca, Informe Final LIFE+ INDEMARES (LIFE07/NAT/E/000732); Instituto de Ciencias del Mar-CSIC: Barcelona, Spain, 2014; Unpublished work.

59. Requena, S.; Gili, J.M. Caracterización ecológica del área marina del Canal de Menorca: Zonas profundas y semiprofundas (100-400 m), Informe Final LIFE+ INDEMARES (LIFE07/NAT/E/000732). 2014. Unpublished work. Available online: https: //www.indemares.es/sites/default/files/informe_final_canal_de_menorca_csic.pdf (accessed on 15 December 2021).

60. Guijarro, B.; Ordines, F.; Pasqual, C.; Valls, M.; Quetglas, A.; Massutí, E. La pesca de ròssec al voltant de l'arxipèlag de Cabrera. In Arxipèlag de Cabrera: Història Natural; Grau, A.M., Fornós, J.J., Mateu, G., Oliver, P.A., Terrasa, B., Eds.; Monogr Soc Hist Nat Balears: Palma, Spain, 2020; Volume 30, pp. 375-391.

61. Roberts, J.M.; Wheeler, A.J.; Freiwald, A. Reefs of the Deep: The Biology and Geology of Cold-Water Coral Ecosystems. Science 2006, 312, 543-547. [CrossRef] [PubMed]

62. Turner, D.L.; Jarrard, R.D.; Forbes, R.B. Geochronology and origin of the Pratt-Welker Seamount Chain, Gulf of Alaska: A new pole of rotation for the Pacific Plate. J. Geophys. Res. Space Phys. 1980, 85, 6547-6556. [CrossRef]

63. Just, J.; Hübscher, C.; Betzler, C.; Lüdmann, T.; Reicherter, K. Erosion of continental margins in the Western Mediterranean due to sea-level stagnancy during the Messinian Salinity Crisis. Geo-Mar. Lett. 2010, 31, 51-64. [CrossRef]

64. Acosta, J. El Promontorio Balear: Morfología Submarina Y Recubrimiento Sedimentario. Ph.D. Thesis; University of Barcelona: Barcelona, Spain, 2005. Available online: https: / / dialnet.unirioja.es/servlet/tesis? codigo=234793\&info=resumen\&idioma=SPA (accessed on 30 July 2021).

65. Iglesias, J.; Ercilla, G.; García-Gil, S.; Judd, A.G. Pockforms: An evaluation of pockmark-like seabed features on the Landes Plateau, Bay of Biscay. Geo-Mar. Lett. 2009, 30, 207-219. [CrossRef]

66. Acosta, J.; Muñoz, A.; Herranz, P.; Palomo, C.; Ballesteros, M.; Vaquero, M.; Uchupi, E. Pockmarks in the Ibiza Channel and western end of the Balearic Promontory (western Mediterranean) revealed by multibeam mapping. Geo-Mar. Lett. 2001, 21, 123-130. [CrossRef]

67. Hovland, M.; Heggland, R.; De Vries, M.; Tjelta, T. Unit-pockmarks and their potential significance for predicting fluid flow. Mar. Pet. Geol. 2010, 27, 1190-1199. [CrossRef]

68. Plaza-Faverola, A.; Bünz, S.; Mienert, J. Repeated fluid expulsion through sub-seabed chimneys offshore Norway in response to glacial cycles. Earth Planet. Sci. Lett. 2011, 305, 297-308. [CrossRef]

69. Díaz, J.A.; Ramírez-Amaro, S.; Ordines, F. Sponges of Western Mediterranean seamounts: New genera, new species and new records. PeerJ 2021, 9, e11879. [CrossRef]

70. Ordines, F.; Ramírez-Amaro, S.; Fernandez-Arcaya, U.; Marco-Herrero, E.; Massutí, E. First occurrence of an Ophiohelidae species in the Mediterranean: The high abundances of Ophiomyces grandis from the Mallorca Channel seamounts. J. Mar. Biol. Assoc. U. K. 2019, 99, 1817-1823. [CrossRef]

71. Forest, J. Campagnes du Professeur Lacaze-Duthiers aux Baleares Juin 1953 et Aout 1954 Crustaces Decapodes. Vie et Milieu 1965, 16, 325-413. Available online: https:/ / eurekamag.com/research/038/039/038039972.php (accessed on 15 December 2021). 
72. Duris, Z. Penaeid and caridean shrimps collected during Soviet expeditions 1974-1980 to the Mediterranean area. In Proceedings of the 6th Col-loquium Crustacea Decapoda Mediterranea, Florence, Italy, 12-15 September 1996; pp. 34-35.

73. Abello, P.; Carbonell, A.; Torres, P. Biogeography of epibenthic crustaceans on the shelf and upper slope off the Iberian Peninsula Mediterranean coasts: Implications for the establishment of natural management areas. Sci. Mar. 2002, 66. [CrossRef]

74. Zariquiey Alvarez, R. Crustaceos Decapodos Ibericos. Inv. Pesq. 1968, 32, 1-83.

75. Garcia-Raso, J.E. Crustacea Decapoda (Excl. Sergestidae) From Ibero-Moroccan Waters. Results of Balgim-84 Expedition. Bull. Mar. Sci. 1996, 58, 730-752.

76. Box, A. Ecología de Caulerpales: Fauna y Biomarcadores. Ph.D. Thesis, University of the Balearic Islands, Palma, Spain, 2008.

77. Mateo-Ramírez, Á.; Urra, J.; Rueda, J.L.; Marina, P.; Raso, J.G. Decapod assemblages associated with shallow macroalgal communities in the northwestern Alboran Sea: Microhabitat use and temporal variability. J. Sea Res. 2018, 135, 84-94. [CrossRef]

78. Noël, P.Y. Clé préliminaire d'identification des Crustacea Decapoda de France et des principales autres espèces d'Europe. Secrétariat de la Faune et de la Flore. Muséum National d'Histoire Naturelle, Paris. Collect. Patrim. Nat. 1992, 9, 1-145.

79. Quetglas, A.; Ordines, F.; Gonzalez, M.; Zaragoza, N.; Mallol, S.; Valls, M.; De Mesa, A. Uncommon pelagic and deep-sea cephalopods in the Mediterranean: New data and literature review. Mediterr. Mar. Sci. 2013, 14, 69. [CrossRef]

80. Corals on seamounts. In Seamounts: Ecology, Fisheries \& Conservation; Pitcher, T.J.; Morato, T.; Hart, P.J.B.; Clark, M.R.; Haggan, N.; Santos, R.S. (Eds.) Blackwell Publishing Ltd.: Oxford, UK, 2007; pp. 1-527. [CrossRef]

81. Williams, A.; Althaus, F.; Schlacher, T.A. Towed camera imagery and benthic sled catches provide different views of seamount benthic diversity. Limnol. Oceanogr. Methods 2015, 13, 62-73. [CrossRef]

82. Massutí, E.; Renones, O.; Carbonell, A. À propos de la présence de Trachyscorpia cristulata echinata (Koehler, 1896) en Méditerranée nord-occidentale. Cybium 1993, 17, 223-228.

83. Merella, P.; Alemany, F.; Grau, A. Nuevos datos sobre la presencia de Pontinus kuhlii (Bowdich, 1825) (Osteichthyes: Scorpaenidae) en el Mediterráneo Occidental. Sci. Mar. 1998, 62, 133-208. [CrossRef]

84. McClain, C.R.; Lundsten, L. Assemblage structure is related to slope and depth on a deep offshore Pacific seamount chain. Mar Ecol. 2014, 36, 210-220. [CrossRef]

85. Du Preez, C.; Curtis, J.M.R.; Clarke, M.E. The Structure and Distribution of Benthic Communities on a Shallow Seamount (Cobb Seamount, Northeast Pacific Ocean). PLoS ONE 2016, 11, e0165513. [CrossRef]

86. Oliver, P.A. Los Recursos Pesqueros del Mediterráneo. Primera Parte: Mediterráneo Occidental. Stud. Rev. GFCM 1983, 59, 1-141.

87. Lozano, P.; Rueda, J.L.; Gallardo-Núñez, M.; Farias, C.; Urra, J.; Vila, Y.; Lopez-Gonzalez, N.; Palomino, D.; Sánchez-Guillamón, O.; Vázquez, J.T.; et al. Habitat distribution and associated biota in different geomorphic features within a fluid venting area of the Gulf of Cádiz (Southwestern Iberian Peninsula, Northeast Atlantic Ocean). In Seafloor Geomorphology as Benthic Habitat; Elsevier BV: Amsterdam, The Netherlands, 2020; pp. 847-861.

88. Palanques, A.; Guillén, J.; Puig, P. Impact of bottom trawling on water turbidity and muddy sediment of an unfished continental shelf. Limnol. Oceanogr. 2001, 46, 1100-1110. [CrossRef]

89. Puig, P.; de Madron, X.D.; Salat, J.; Schroeder, K.; Martín, J.; Karageorgis, A.P.; Palanques, A.; Roullier, F.; Lopez-Jurado, J.L.; Emelianov, M.; et al. Thick bottom nepheloid layers in the western Mediterranean generated by deep dense shelf water cascading. Prog. Oceanogr. 2013, 111, 1-23. [CrossRef]

90. Martin, J.; Puig, P.; Palanques, A.; Giamportone, A. Commercial bottom trawling as a driver of sediment dynamics and deep seascape evolution in the Anthropocene. Anthropocene 2014, 7, 1-15. [CrossRef]

91. Kaiser, M.J.; Collie, J.S.; Hall, S.J.; Jennings, S.; Poiner, I.R. Modification of marine habitats by trawling activities: Prognosis and solutions. Fish Fish. 2002, 3, 114-136. [CrossRef]

92. Clark, M.R.; Althaus, F.; Schlacher, T.; Williams, A.; Bowden, D.A.; Rowden, A. The impacts of deep-sea fisheries on benthic communities: A review. ICES J. Mar. Sci. 2016, 73, i51-i69. [CrossRef]

93. Scientific, Technical and Economic Committee for Fisheries Sub-Group Meeting on Sensitive and Essential Fish Habitats in the Mediterranean Sea (STECF/SGMED-06-01). 2006, p. 48, Unpublisher work. Available online: https://stecf.jrc.ec.europa.eu/ documents /43805/122927/07-06_SG-MOS+07-02+-+Evaluation+of+Closed+Areas.pdf (accessed on 15 December 2021).

94. Bo, M.; Numa, C.; Otero, M.D.M.; Orejas, C.; Garrabou, J.; Cerrano, C.; Kružić, P.; Antoniadou, C.; Aguilar, R.; Kipson, S.; et al. Overview of the conservation status of Mediterranean anthozoa. In Overview of the Conservation Status of Mediterranean Anthozoa; IUCN: Málaga, Spain, 2017; p. 73. [CrossRef]

95. Finucci, B.; Bineesh, K.; Cotton, C.; Dharmadi, D.; Kulka, D.; Neat, F.; Pacoureau, N.; Rigby, C.; Tanaka, S.; Walker, T. Iucn Centrophorus uyato. In IUCN Red List of Threatened Species; IUCN: Málaga, Spain, 2019.

96. Barberá, C.; Moranta, J.; Ordines, F.; Ramón, M.; De Mesa, A.; Díaz-Valdés, M.; Grau, A.M.; Massutí, E. Biodiversity and habitat mapping of Menorca Channel (western Mediterranean): Implications for conservation. Biodivers. Conserv. 2012, 21, 701-728. [CrossRef]

97. Grinyó, J.; Gori, A.; Ambroso, S.; Purroy, A.; Calatayud, C.; Dominguez-Carrió, C.; Coppari, M.; Iacono, C.L.; López-González, P.J.; Gili, J.-M. Diversity, distribution and population size structure of deep Mediterranean gorgonian assemblages (Menorca Channel, Western Mediterranean Sea). Prog. Oceanogr. 2016, 145, 42-56. [CrossRef]

98. Grinyó, J.; Garriga, A.; Soler-Membrives, A.; Santín, A.; Ambroso, S.; López-González, P.J.; Díaz, D. Soft corals assemblages in deep environments of the Menorca Channel (Western Mediterranean Sea). Prog. Oceanogr. 2020, 188, 102435. [CrossRef] 
99. Santín, A.; Grinyó, J.; Ambroso, S.; Uriz, M.J.; Gori, A.; Dominguez-Carrió, C.; Gili, J.-M. Sponge assemblages on the deep Mediterranean continental shelf and slope (Menorca Channel, Western Mediterranean Sea). Deep. Sea Res. Part I Oceanogr. Res. Pap. 2018, 131, 75-86. [CrossRef]

100. Bo, M.; Bertolino, M.; Borghini, M.; Castellano, M.; Harriague, A.C.; Di Camillo, C.G.; Gasparini, G.; Misic, C.; Povero, P.; Pusceddu, A.; et al. Characteristics of the Mesophotic Megabenthic Assemblages of the Vercelli Seamount (North Tyrrhenian Sea). PLoS ONE 2011, 6, e16357. [CrossRef]

101. De la Torriente, A.; Serrano, A.; Fernández-Salas, L.M.; García, M.; Aguilar, R. Identifying epibenthic habitats on the Seco de los Olivos Seamount: Species assemblages and environmental characteristics. Deep. Sea Res. Part I Oceanogr. Res. Pap. 2018, 135, 9-22. [CrossRef]

102. De La Torriente, A.; González-Irusta, J.M.; Aguilar, R.; Fernández-Salas, L.M.; Punzón, A.; Serrano, A. Benthic habitat modelling and mapping as a conservation tool for marine protected areas: A seamount in the western Mediterranean. Aquat. Conserv. Mar. Freshw. Ecosyst. 2019, 29, 732-750. [CrossRef]

103. Serrano, A.; Cartes, J.; Papiol, V.; Punzón, A.; García-Alegre, A.; Arronte, J.; Ríos, P.; Lourido, A.; Frutos, I.; Blanco, M. Epibenthic communities of sedimentary habitats in a NE Atlantic deep seamount (Galicia Bank). J. Sea Res. 2017, 130, 154-165. [CrossRef]

104. Galil, B.; Zibrowius, H. First benthos samples from Eratosthenes Seamount, eastern Mediterranean. Senckenberg. Marit. 1998, 28, 111-121. [CrossRef]

105. Grinyó, J.; Gori, A.; Greenacre, M.; Requena, S.; Canepa, A.; Iacono, C.L.; Ambroso, S.; Purroy, A.; Gili, J.-M. Megabenthic assemblages in the continental shelf edge and upper slope of the Menorca Channel, Western Mediterranean Sea. Prog. Oceanogr. 2018, 162, 40-51. [CrossRef] 